918.9

D 358

1906

HECTOR F. DECOUD

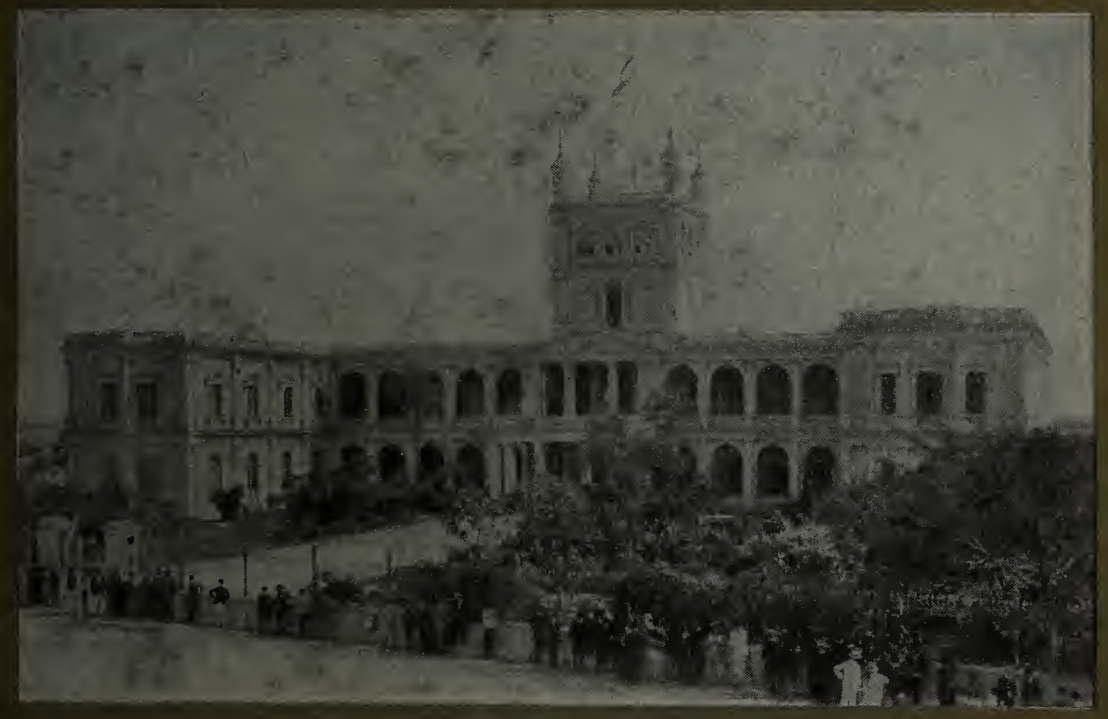

GEOGRAFIA DE

LA REPÚBLICA

DEL PARAGUAY 


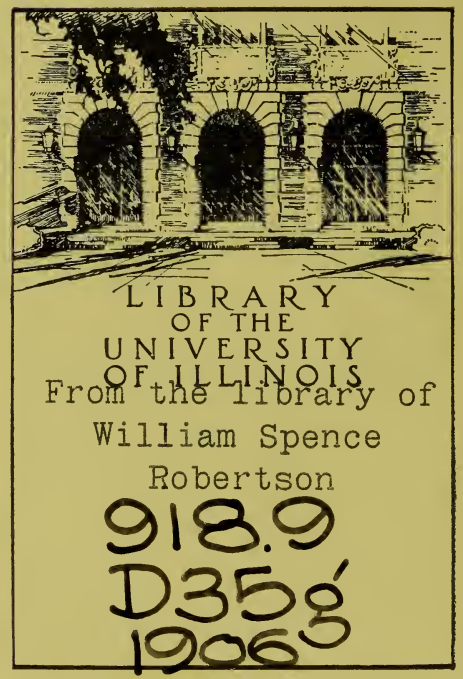


S. Rohertaon Asmución del Paragnay,
September 11, 19,6. 

Aprobado y adoptado como texto por el Consejo S. de Educación para las Escuelas de la República

\section{Geografía de la}

República del Paraguay

por

\section{Héctor F. Decoud}

Premiada con medalla de oro en la Exposición de Bruselas

$$
5^{\text {a }} \text { Edición }
$$

Con un mapa, el Pabellón y escudo Nacional y 50 grabados

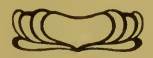

Leipzig:

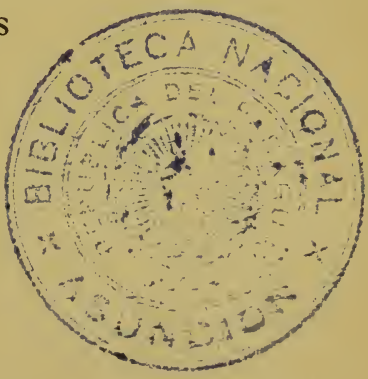

Imprenta de F. A. Brockhaus

1906. 



\section{8,9 \\ 0359 \\ 14t}

\section{DEFINICIONES GENERALES.}

I.

\section{De la Geografía.}

La Geografía es la ciencia que trata del conocimiento y descripción de la tierra.

Según los varios puntos de vista que se considere á la Tierra, ya como astro, ya como cuerpo físico ó ya como morada del hombre, la Geografía puede dividirse en tres partes principales: Astronómica, Física y Política.

la Geografía Astronómica considera la tierra como un astro y dá á conocer sus movimientos y relaciones con los demás astros.

La Geografía Física examina la superficie de la tierra y enseña su aspecto, desigualdades, climas, producciones, estructura interior, substancias de que se compone y habitantes.

La Geografía Política estudia los estados ó naciones, formas de gobierno, religiones, usos y costumbres, considerando á la Tierra como habitación del hombre.

Toma también la Geografía diversas denominaciones, según el fin especial que se proponga. Así, se llama Hidrografía, cuando se ocupa exclusivamente de las aguas; Etnografía, de las razas; Zoología, Botánica y Mineralogía, de los animales, vegetales y minerales; Corografía y Topografía si se trata de un país, de una comarca ó de un pequeño territorio, etc. etc.

El estudio de la Geografía es de suma importancia, y por consiguiente, indispensable su conocimiento.

El hombre en su patria no debe hallarse confinado en la pequeña región donde ha nacido; debe colocarse en relación con los demás seres semejantes á él, para ilustrar su inteligencia, satisfacer sus múltiples y variadas necesi- 
dades. A la prosecución de este plausible fin, la Geografía le ofrece los medios que necesita: al marino, para explorar las inmensidades del océano; al comerciante, para buscar las producciones y aproximar á los consumidores; al político, para la administración y gobierno de los pueblos; al militar, para sus planes de guerra, y finalmente, esta ciencia es de suma utilidad para todo hombre de alguna cultura, pues casi en todos los actos de la vida se hace imprescindible su conocimiento.

II.

\section{De la Tierra.}

Forma y Dimensiones. - La Tierra es de forma esférica, ligeramente aplanada en las extremidades de su eje de rotación, que se llaman polos.

Sus dimensiones principales son las siguientes:

Radio ecuatorial .........................

$"$ polar ................................

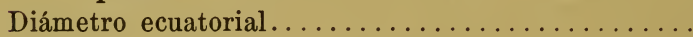

" polar ó eje de la tierra ..............

Achatamiento de la tierra en cada polo...........

Extensión lineal del ecuador ...................

" $"$ de un meridiano ...............

Superficie de la tierra.......................

6.377.398 metros

6.356 .080 "

12.754 .796 "

12.712 .160

42.630 "

40.070 .376 "

40.003 .423 "

Volumen de la tierra ..................... 1.083.000.000.000 kil. ${ }^{3}$

La superficie de la Tierra se compone de dos partes distintas, una sólida que ocupa el 27 por ciento, ó sea 137.686.693 kil. ${ }^{2}$ y otra LíquidA el 73 por ciento, ó sea $372.264 .021 \mathrm{kil}^{2}{ }^{2}$ que equivale próximamente á las 3 cuartas partes de la superficie total. Del 27 por ciento de la superficie del globo, corresponde el 0.2 por ciento à la República del Paraguay.

\section{III.}

\section{Puntos cardinales.}

El Norte, Sur, Este y Oeste son los cuatro puntos cardinales señalados en el horizonte. Los puntos intermediarios entre el Norte y Este, Norte y Oeste, Sur y Este y Sur y Oeste se 
designan respectivamente con los nombres de Noreste, Noroeste, Sureste, Suroeste. El conjunto de todos estos puntos señalados y las subdivisiones de que son susceptibles, forma la RoSA DE LOS VIENTOS.

Los vientos sirven para indicar los rumbos ó lugares que rodean al observador.

Para conocer los puntos cardinales en cualquier situación que se encuentre el observador, basta colocar la derecha hacia el punto donde sale el sol tomando la izquierda la dirección en donde parece ponerse. En tal caso, el Norte queda hacia el frente del mismo observador, el Sur hacia atrás, el Este á la derecha y el Oeste á la izquierda.

En los mapas ó cartas geográficas se ha convenido colocar el Norte en la parte superior, el Sur en la inferior, el Este á la derecha y el Oeste á la izquierda.

\section{IV.}

\section{Círculos Geográficos.}

Eu Ecuador ó líNea Equinoccial es un gran círculo imaginario que se encuentra á igual distancia de los polos y divide la tierra en dos grandes porciones iguales; una al Norte, que se llama HEMISFERIO NORTE ó BOREAL, y otra al Sur, que se llama HEMISFERIO SUR ó AUSTRAL. El primero contiene tres veces más tierra que el segundo.

Meridianos son círculos imaginarios que pasan por los polos é interceptan el Ecuador perpendicularmente, dividiendo à la tierra en dos hemisferios, el oriental y el occidental. Todos los meridianos son iguales y su número es infinito.

Se dice que hay MEDIODIa en un lugar, cuando los rayos de sol caen en dicho punto verticalmente ó el sol pasa por el meridiano del lugar; de suerte que todos los puntos situados sobre un mismo meridiano deben tener mediodía en el mismo instante, y los situados al Este ú Oeste unos de otros, mediodías diferentes.

Para los lugares situados á quince grados de distancia entre si, la diferencia de sus mediodías, sería de una hora, ya por defecto ó ya por exceso, según que la posición se encuentre al Este ú Oeste. Esto proviene de que la tierra gira sobre su eje de Oeste á Este, presentando primero delante 
del sol los puntos que se encuentran más al Este y después sucesivamente los situados más al Oeste.

En la tabla siguiente se ven las diferencias del tiempo originadas por la diversidad de longitud existente entre la Asunción y algunas ciudades europeas, sur y norte-americanas por una parte, y entre aquella misma ciudad y varias otras del interior paraguayo.

Para mediodía en Asunción, es en el mismo instante en:

Villa Rica ..... 12 h. 4 m. 36 s. $p . m$.

" Concepción. $12 \quad 1 \quad 39 \quad$ ”

" Encarnación $\begin{array}{llll}12 & 7 & 12 & \text { ” }\end{array}$

” San Pedro . $12 \quad 2 \quad 49 \quad$ ”

" del Pilar... $1157 \quad 59$ a.m.

Ibitimí ....... $12 \quad 3 \quad 11 \quad$ p. $m$.

Caazapá....... $12 \quad 4 \quad 44$ ”

San Estanislao .. $12 \quad 4 \quad 19$ »

Formosa....... 1158

Corrientes ..... 1155

Paraná........ 1148

Rosario........ 1148

Santa Fé ...... 1147

La Plata ...... 1158

Buenos Aires ... 1157

Córdoba ....... 1133

Mendoza ...... $11 \quad 15$
25 a. $m$.

16 》

29 》

25 "

49 »

19 "

11 "

$52 》$

59 》
Montevideo ..... 12 h. 5 m. 51 s. p. $m$.

Rio de Janeiro .. 125908 ”

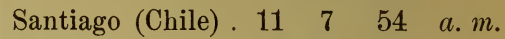

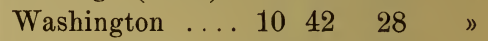

Nueva York.... $10 \quad 51 \quad 39$ ”

Génova....... $415 \quad 17 \quad$ p. $\mathrm{m}$.

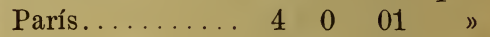

Madrid ........ $3535 \quad 54$ ”

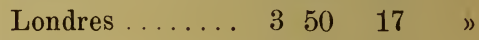

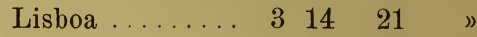

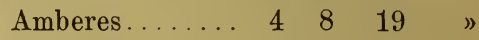

Constantinopla .. $5456 \quad 33 \quad$ ”

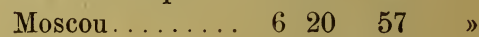

Roma ........ $440 \quad 26$ 》

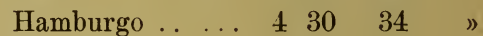

Greenwich ..... $350 \quad 40$ ”

Paralelos son círculos imaginarios trazados en la misma dirección del Ecuador.

Los paralelos son desiguales; mayores los más próximos al Ecuador y menores los más cercanos á los polos.

Los puntos situados al Este ó al Oeste unos de otros, tienen un mismo paralelo, y en cambio los situados al Norte ó al Sur unos de otros, tienen paralelos diferentes.

El número de paralelos es infinito, existiendo empero cuatro que tienen nombres particulares: el Trópico de Cáncer, al Norte del Ecuador, y el de Capricornio al Sur del mismo, y los círculos polares Ártico y Antártico, $23^{\circ} 27^{\prime} 17^{\prime \prime}$ del Ecuador los primeros y de los polos Norte y Sur respectivamente, los segundos.

Llevan estos paralelos nombres especiales que sirven para determinar las tres grandes temperaturas que reinan en la superficie del globo, dividiendo á éste en cinco grandes zonas; la 


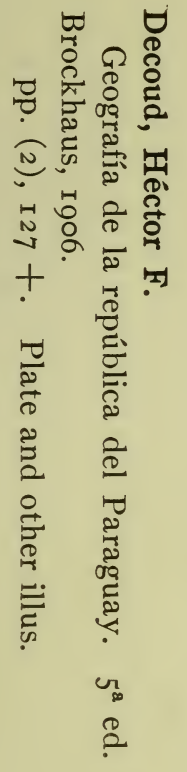

ico de Cáncer y el de Caprilécimas partes de la superficie re el Trópico de Cáncer y el iustral, entre el Trópico de rtico, que ambas comprenden zs; la fría DeL Norte, desde del mismo nombre; la GLACIAL olo del mismo nombre, y los $r$ de un décimo.

son originadas por la dirección de ;lobo; así en la zona tórrida los mplada oblicuamente y en las glade la República abraza una extenmientras la templada comprende urtas partes.

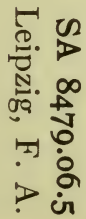

\section{ongitud.}

cia que lo separa del Ecuador; ador hacia los Polos, desde $\checkmark$ latitud del Ecuador 0 grado

Norte ó Sur, según que el punto dado se encuentre en la parte boreal ó austral del Ecuador. Hay 90 grados de latitud Norte y 90 grados de latitud Sur, según la posición que ocupe el punto dado con respecto al Ecuador.

Longitud de un punto es la distancia que lo separa de un meridiano determinado.

La longitud se cuenta al Este ú Oeste del primer meridiano hasta 180 grados, según que se encuentren los puntos dados al Oriente ú Occidente del meridiano inicial ó primer meridiano.

Hay 180 grados de longitud oriental y 180 grados de longitud occidental. 
del sol los puntos que se encuentran más al Este y después sucesivamente los situados más al Oeste.

En la tabla siguiente se ven las diferencias del tiempo originadas por la diversidad de longitud existente entre la Asunción y algunas ciudades europeas, sur y norte-americanas por una parte, y entre aquella misma ciudad y varias otras del interior

Para mediodía en Asunción, e Villa Rica ..... 12 h. 4 m. 36 s. $p$.

》 Concepción. $12 \quad 1 \quad 39$,

” Encarnación $\begin{array}{llll}12 & 7 & 12\end{array}$,

” San Pedro . $12 \quad 2 \quad 49$,

» del Pilar... $1157 \quad 59$ a.

Ibitimí . . . . . . 12 3 $311 \quad p$.

Caazapá....... $12 \quad 4 \quad 44$

San Estanislao .. $12 \quad 4 \quad 19$,

Formosa...... $11 \quad 58 \quad 25 a$.

Corrientes ..... $1155 \quad 16$,

Paraná....... $1148 \quad 29$,

Rosario........ $1148 \quad 25$,

Santa Fé ...... $1147 \quad 49$,

La Plata ...... $1158 \quad 19$,

Buenos Aires ... $11 \quad 57 \quad 11$,

Córdoba ....... $1133 \quad 52$,

Mendoza ...... $11 \quad 15 \quad 59$,

Paralelos son círculos dirección del Ecuador.

Los paralelos son desiguء Ecuador y menores los más ।

Los puntos situados al Es un mismo paralelo, y en cam unos de otros, tienen paralelc

El número de paralelos e: que tienen nombres particula] del Ecuador, y el de Caprico los polares Ártico y Antárticc meros y de los polos Norte y sur respectivamente, los segundos.

Llevan estos paralelos nombres especiales que sirven para determinar las tres grandes temperaturas que reinan en la superficie del globo, dividiendo á éste en cinco grandes zonas; la 
TóRRIDA, comprendida entre el trópico de Cáncer y el de Capricornio, que abraza casi las cuatro décimas partes de la superficie terrestre; la templada BOREal, entre el Trópico de Cáncer y el círculo polar Ártico; la templada austral, entre el Trópico de Capricornio y el círculo polar Antártico, que ambas comprenden algo más de las cinco décimas partes; la fría DeL Norte, desde el círculo polar Ártico hasta el polo del mismo nombre; la GLACIAL Sur, desde el Antártico hasta el polo del mismo nombre, y los dus ocupan una anchura poco menor de un décimo.

Estas diversidades en la temperatura son originadas por la dirección de los rayos solares sobre la superficie del globo; así en la zona tórrida los rayos del sol caen verticalmente, en la templada oblicuamente y en las glaciales más oblicuamente todavía.

La parte Norte de la región Oriental de la República abraza una extensión de $1^{\circ} 21^{\prime} 03^{\prime \prime}$ de la zona tórrida, mientras la templada comprende $4^{\circ} 3^{\prime} 43^{\prime \prime}$, ó sea algo mas de las tres cuartas partes.

\section{V.}

\section{Latitud y Longitud.}

Latitud de un lugar es la distancia que lo separa del Ecuador; la latitud se cuenta desde el Ecuador hacia los Polos, desde 0 grados hasta 90 grados, siendo la latitud del Ecuador 0 grado y la de los polos 90 grados.

Las latitudes, pues, pueden ser Norte ó Sur, según que el punto dado se encuentre en la parte boreal ó austral del Ecuador.

Hay 90 grados de latitud Norte y 90 grados de latitud Sur, según la posición que ocupe el punto dado con respecto al Ecuador.

Longitud de un punto es la distancia que lo separa de un meridiano determinado.

La longitud se cuenta al Este ú Oeste del primer meridiano hasta 180 grados, según que se encuentren los puntos dados al Oriente ú Occidente del meridiano inicial ó primer meridiano.

Hay 180 grados de longitud oriental y 180 grados de longitud occidental. 
Cada grado está dividido en 60 minutos y el minuto en 60 segundos.

111 kilómetros equivalen á la distancia entre cada grado de latitud, mientras que entre cada grado de longitud varia de 111 kilómetros (hacia el Ecuador) hasta anularse completamente en los polos, donde terminan en un mismo punto todos los grados de longitud.

En la adopción del primer meridiano no hay uniformidad, sirviéndose generalmente cada país del que pasa por sus principales observatorios, lo que complica algo los cálculos geográficos. En Inglaterra, es el meridiano de Greenwich; en Francia, el de Paris; en España, el de Madrid ó el de San Fernando; en Alemania, el de la isla de Hierro; en los Estados Unidos, el de Washington; en el Brasil, el de Rio Janeiro; en Chile, el de Santiago; en la República Argentina, el de Córdoba, etc.

Es muy importante saber determinar en un mapa la situación geográfica de un lugar, y he aquí el procedimiento que á ese efecto debe seguirse.

\section{VI.}

\section{Determinación de la Latitud.}

Para determinar la latitud de un punto, según la clase de mapa que se tenga delante, hay que observar si es un mapa mundi ó un mapa del sistema de Mercator; si es en el primero, las latitudes están marcadas alrededor de la circunferencia en las extremidades de los paralelos, y si es en el segundo, á la derecha ó izquierda.

Dado el punto, se tiene que observar si está arriba ó abajo del Ecuador, para saber desde luego si tiene latitud Norte ó Sur. Una vez impuesto de esto, se observa el paralelo que pasa por el punto en referencia, y en su extremidad está indicado el grado respectivo.

Pero no es suficiente determinar la latitud de un lugar para conocer positivamente su situación, pues todos los puntos que se encuentran situados sobre un paralelo, tienen la misma latitud. Así, por ejemplo, no quedaría determinada la posición de una casa con solo expresar la calle sobre la que se encuentra; sería necesario indicar también las otras calles que la cruzan; idéntica cosa sucede con la situación geográfica de los lugares, y es por esta razón que se hace necesario determinar también la lóngitud. 
VII.

\section{Determinación de la Longitud.}

Dado un punto cuya longitud se trata de hallar, se observará si está á la derecha ó á la izquierda del primer meridiano de que ya hemos hablado, y según su situación tendrá longitud oriental ú occidental.

Las longitudes se hallan marcadas en los MAPA-MUNDis en el Ecuador ó en los círculos polares, en las extremidades de los meridianos y en los mapas del sistema de Mercator, en la parte superior ó inferior.

\section{VIII.}

\section{Determinación de la situación geográfica de un punto.}

Conocido el procedimiento que se debe seguir para determinar las latitudes y longitudes de los puntos, es fácil hallar su situación geográfica, que no es más que la determinación de la latitud y longitud de un mismo punto.

A continuación se expresa la situación geográfica de varios puntos de la República.

\begin{tabular}{|c|c|c|c|c|c|c|c|}
\hline Puntos & $\mathrm{La}$ & itud & Sur & Orier & $\begin{array}{l}\text { Lon } \\
\text { tal ú } \\
\text { le Asi }\end{array}$ & $\begin{array}{l}\text { itud } \\
\text { Occide } \\
\text { nción }\end{array}$ & ntal \\
\hline Asunción & $25^{\circ}$ & $16^{\prime}$ & $40^{\prime \prime}$ & $0^{\circ}$ & $00^{\prime}$ & $00^{\prime \prime}$ & \\
\hline Villa del Pilar & $26^{\circ}$ & $52^{\prime}$ & $24^{\prime \prime}$ & $0^{\circ}$ & $30^{\prime}$ & $28^{\prime \prime}$ & 0. \\
\hline "Concepción & $23^{\circ}$ & $23^{\prime}$ & $8^{\prime \prime}$ & $0^{\circ}$ & $24^{\prime}$ & $56^{\prime \prime}$ & E. \\
\hline " Rica ...... & $25^{\circ}$ & $48^{\prime}$ & $55^{\prime \prime}$ & $1^{\circ}$ & $9^{\prime}$ & $1^{\prime \prime}$ & 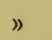 \\
\hline 1) Encarnación & $27^{\circ}$ & $20^{\prime}$ & $16^{\prime \prime}$ & $1^{\circ}$ & $48^{\prime}$ & $1^{\prime \prime}$ & $»$ \\
\hline Paraguarí ....... & $25^{\circ}$ & $36^{\prime}$ & $51^{\prime \prime}$ & $0^{\circ}$ & $30^{\prime}$ & $11^{\prime \prime}$ & ” \\
\hline Caazapá . & $26^{\circ}$ & $11^{\prime}$ & $18^{\prime \prime}$ & $1^{0}$ & $11^{\prime}$ & $11^{\prime \prime}$ & $»$ \\
\hline San Estanislao & $24^{\circ}$ & $38^{\prime}$ & $31^{\prime \prime}$ & $1^{\circ}$ & $4^{\prime}$ & $45^{\prime \prime}$ & $»$ \\
\hline Villeta ....... & $25^{\circ}$ & $30^{\prime}$ & $55^{\prime \prime}$ & $0^{\circ}$ & $4^{\prime}$ & $35^{\prime \prime}$ & $"$ \\
\hline Carapeguá & $25^{\circ}$ & $45^{\prime}$ & $31^{\prime \prime}$ & $0^{\circ}$ & $24^{\prime}$ & $4^{\prime \prime}$ & $»$ \\
\hline Emboscada & $25^{\circ}$ & $10^{\prime}$ & $56^{\prime \prime}$ & $0^{\circ}$ & $19^{\prime}$ & $42^{\prime \prime}$ & $»$ \\
\hline
\end{tabular}


A los habitantes de un mismo meridiano y á igual distancia del Ecuador, uno al Norte y otro al Sur, se les llama ANTEcos.

Los antecos tienen la misma longitud y latitud, pero ésta de nombre contrario; tienen la misma hora del día y las estaciones opuestas.

(Los habitantes de Asunción no tienen antecos, porque el punto dado se encuentra situado en el Océano Atlántico.)

Se llaman PERIEcos los habitantes de un mismo paralelo, distantes entre sí $180^{\circ}$.

Los periecos tienen la misma latitud y longitud contraria; sus estaciones son las mismas y sus horas del día opuestas.

(Los periecos de Asunción son los habitantes del Norte de la Australia, en su parte occidental.)

Se llaman antípodas los habitantes de los extremos de un diámetro terrestre, estando á igual distancia del Ecuador, pero en hemisferios distintos y con $180^{\circ}$ de diferencia en longitud.

Los antípodas tienen longitud opuesta, la misma latitud, pero de nombre opuesto y opuestas también las horas del día y las estaciones.

(Los habitantes de Asunción no tienen antípodas, porque el punto dado se encuentra en el mar oriental, al Norte de la isla Formosa.)

IX.

\section{De la parte sólida.}

Las grandes divisiones naturales de la tierra se llaman conTINENTES.

Hay tres continentes: el Antiguo ú Oriental, que comprende Europa, Asia y África; el Nuevo ú Occidental que comprende América, y el tercero que comprende Australia ó Nueva Holanda.

(La República del Paraguay se halla situada en América ó Nuevo Continente, descubierto en 1492 de nuestra era). 
Cinco son las partes del mundo: Europa, África, Asia, AuÉRICA y OCEANía, La penúltima forma dos grandes porciones: la AMÉrica del Norte y la AMÉRICa DeL Sud, encontrándose casi en el centro de ésta la República que habitamos.

Las porciones de tierra menores que los continentes y rodeadas de agua por todas partes, se conocen con el nombre de IsLas. (Ejemplo: la de Yaciretá en el río Alto Paraná y la de San Francisco en el río Alto Paraguay.)

Islotes son las islas pequeñas. (En todo el curso de los ríos Paraguay y Paraná se encuentran numerosísimos.)

Un conjunto de islas se llama Archipiélago.

Bancos son los lugares arenosos y poco profundos de los mares y ríos. Cuando éstos son movedizos se llaman SiRTes. (Frente al puerto de la Asuncion se encuentra un gran banco de arena.)

Se llaman Escollos las rocas á flor de agua, y cuando están próximas á las costas, ARRecifes. (En el río Paraná existen muchos de estos últimos que dificultan la navegación.)

A las orillas de los mares y ríos se da el nombre de Costas; si son bajas, Playas. (Ejemplo: la playa formada por la bahía en los bajos del Cabildo.)

Península es una extensión de tierra rodeada de agua, excepto en una parte, por la que se une al continente.

Una faja angosta de tierra que une dos grandes porciones de ella, se denomina Istuo.

$\mathrm{C}_{A B O}$ es una punta de tierra que se interna en el agua; cuando es alto y peñascoso, Promontorio. Toma el nombre de Punta, cuando la parte que penetra en el agua es de poca extensión (v. gr.: el "Itá-pyta-punta», en las inmediaciones y al Oeste de la capital).

Dunas son las colinas arenosas que se encuentran en las orillas de los mares y los ríos. (Al Sur de la isla Yaciretá se encuentra una de ellas.)

Llámase Región ó Comarca una extensión de tierra que se distingue de otras por ciertos caracteres físicos. 
PAís es una comarca cuyos habitantes están sujetos á las mismas leyes, idioma é idénticas costumbres. (Ejemplo: la República del Paraguay.)

Las partes llanas sin accidentes notables se llaman LLANuras ó Luanos. Toman distintos nombres en cada país: así en la República Argentina le llaman PaMpas, en la América del Norte Praderas, y en el Paraguay comunmente Campos. (Ejemplo: los de Misiones, Caazapá y Villa Concepción.)

Las llanuras áridas desprovistas de toda vegetación se llaman Desiertos. Oasis es la parte fértil en medio de un desierto.

En la República no existen Desiertos, pues puede asegurarse sin exageración alguna que no hay terrenos que no sean susceptibles de cultivo. Aplícase en cambio entre nosotros el mismo nombre de DESIERTo para significar los lugares vírgenes sin moradores. Los bosques del Departamento Occidental son grandes desiertos, tomada la palabra en la última acepción.

Los terrenos que se encuentran entre dos montañas ó colinas, llámanse VALLes. (Ejemplo: la parte comprendida entre los cerros de Costa-pucú, Pirayú, Guazuvirá é Ibitipané por un lado y la Cordillera de los Altos por otro.) Sin embargo, entre nosotros se conoce con el nombre de vaLLES las partes pobladas, comprendidas entre dos bosques, tales como Vallepucú en el partido de AAreguá y Valle-caré en el de Villa Concepción.

Bosques, Montes ó Selvas son grupos considerables de árboles. (En la República existen grandes bosques que suministran inagotables cantidadés de maderas, destacándose entre ellos, los del Alto Paraná y Departamento Occidental.)

Las cavidades más ó menos profundas que se encuentran en e interior de los peñascos, se denominan Grutas y Cavernas, y cuando son poco profundas, Cuevas.

Estas cavidades están, á menudo, adornadas de Estalactitas y Estalacmitas, que son masas calcáreas de forma cónica que penden de la bóveda ó se apoyan en el suelo respectivamente.

(La gruta más conocida en la República, es la del cerro Santo Tomás, en Paraguarí.)

Montañas son las grandes elevaciones de tierra; las menores 
elevaciones se llaman Cerros, Colinas y Lomas. (Ejemplo: las montañas de Amambay y Mbaracayú; los cerros Jhú y Santo Tomás en el partido de Paraguarí; las colinas de Tacumbú y Villa Hayes, la primera próxima á la capital y la segunda en el mismo pueblo de dicha villa; y las lomas de Ibitytí é Ita-Ibaté en el partido de Villeta.)

La parte superior de una montaña se llama Cima ó Cumbre; FaLdas ó Laderas los lados; y Pué, la parte de donde se separa del llano y comienza la elevación.

Cordillera es una serie de montañas unidas unas con otras. (Ejemplo: la cordillera de los Altos.)

Mesa ó Meseta son las partes llanas que coronan ciertas montañas. (Los pueblos de Emboscada y Areguá se hallan situados sobre mesetas.)

Peñón es una roca aislada de más ó menos elevación. (Ejemplo: el peñón que se encuentra en el río Paraguay, frente á Limpio.)

Los pasos angostos que ofrecen las montañas, se llaman Gargantas ó Desfiladeros. (Ejemplo: los de Escurra, Pedroso y Cabañas, en la cordillera de los Altos.)

Las nieves perpetuas que cubren las cumbres de las más altas montañas se llaman Ventisqueros. (En la República á causa de la poca elevación de sus montañas, no existen.)

Las masas de nieves que caen de las altas montañas, derribando todo á su paso, se llaman Auudes.

VolCANes son las montañas que arrojan por su cima humo, ceniza, llama y sustancia derretidas que se denominan Lavas. El Cráter es la abertura del volcán.

Se llaman Volcanes extintos los que han dejado de estar en erupción.

TERremotos son las trepidaciones más ó menos violentas que experimenta la superficie terrestre, ocasionadas por fluidos ígneos comprimidos.

(En el Paraguay no existen volcanes, ni se ha experimentado ningún terremoto que haya ocasionado estragos.) 


\section{$-12-$}

Orografía es la parte de la Geografía que se ocupa de la descripción de las montañas.

$\mathrm{X}$.

\section{De la parte líquida.}

A la parte de la Geografía que trata de la descripción de las aguas se llama Hidrografía.

Se da el nombre de Mar ú OcÉano á la porción considerable de agua salada que cubre las tres cuartas partes de la superficie del globo.

Llámase también MAR en sentido restrictivo á una parte del Océano que se introduce en el interior de la tierra. (Ejemplo: el mar de las Antillas).

El OcÉano se divide en cinco partes: el Atrántico entre el antiguo y el nuevo continente; eL Pacífico ó Gran OcÉano, entre el antiguo continente y la Australia por un lado y la América por otro; el Índico, entre Africa, Asia y Australia; los OcÉanos Glaciales Ártico y Antrártico, que se extienden desde sus círculos polares hasta los polos respectivos.

Se denominan Golfos á las partes del mar que penetran profundamente en la tierra. Cuando estas entradas son pequeñas toman los nombres de BaHía ó Ensenada.

Una pequeña bahía que sirve de abrigo á las embarcaciones y generalmente mejorada por el arte, se llama PuERTo.

(Ejemplo: el puerto de la Asunción.)

Un paso angosto de mar comprendido entre dos tierras se denomina Estrecho.

Las grandes masas de agua en medio del continente se llaman Lagos. (Ejemplo: el de Titicaca entre P'erú y Bolivia.) Cuando son de pequeña extensión se llaman Lagunas, (tales como las de Ipoá é Ipacaraí, que son las principales de la República y que se les llama comunmente LAGos).

Pantanos, Esteros y Bañados son aguas estancadas de poca profundidad y generalmente llenas de vegetación. Los lugares 
próximo á ellos suelen ser, por lo general, malsanos. (Ejemplo: el bañado de Tacumbú y los esteros de Ipoá y Bellaco.)

Las aguas que brotan espontáneamente de la tierra con carácter permanente se llaman Manantiales.

Los manantiales y fuentes se forman de las aguas pluviales absorvidas por la tierra y que vuelven á su superficie. En Asunción, la población en general se provee de agua de los manantiales que circundan la capital, gozando algunas de ellas de bastante reputación por sus saludables condiciones, tales como el Icuá-pacobá é Icuá-hospital.

ToRRENTEs son las corrientes de agua rápidas y momentáneas originadas por las lluvias ó por el derretimiento de las nieves.

Las pequeñas corrientes de agua provenientes de manantiales y fuentes se llaman ARroyos. (Ejemplo: el arroyo Itay que limita al Este el distrito de la capital.)

Ríos son las grandes corrientes de agua.

Los ríos se forman de la reunión de varios arroyos y á veces nacen directamente de los lagos y lagunas. (Ejemplo: el río Paraná formado de la reunión de varios arroyos, y el río Salado y el Negro, que nacen de la laguna Ipacaraí é Ipoá respectivamente.)

Las márgenes de los ríos se designan con el nombre de OrILla DERECHA é IZqUIERDA. Para distinguirla, el observador mira en dirección de la corriente y tiene á su diestra la orilla derecha y á su siniestra la izquierda. La Asunción se encuentra en la márgen izquierda y Villa Hayes en la derecha del río Paraguay.

Lecho, Alveo ó Cauce, es el espacio de terreno que ocupa la corriente del río.

El paraje de reunión de dos corrientes de agua en un solo cauce, se llama Unión ó Confluencia. (Ejemplo: el lugar donde se junta el río Paraná con el Paraguay.)

Los diversos ríos y arroyos que llevan sus aguas ó corrientes á otros mayores, se llaman Afluentes ó Tributarios. (Ejemplo: los ríos Apa, Aquidaban, Ipané, Jejuí, Piribebuy, Salado, Tebicuarí, etc. y los arroyos Surubiy y Paray, son afluentes del río Paraguay.) 
El lugar donde una corriente se precipita al mar ó á un ago, se llama Desembocadura.

Una pequeña masa de agua formada de un arroyo y detenida por una calzada ú otro obstáculo cualquiera, se llama EsTaNqUE.

DeLta ó D GRIEga $(\triangle)$ es el espacio de tierra ó islote formado por la división de un río en dos ó más brazos. (Ejemplo: el delta formado por los dos brazos del río Pilcomayo.)

La Cuenca de un río son todos los terrenos cuyas aguas van á confundirse en el mismo. (Así, la cuenca del río Paraguay comprende todo el territorio adyacente que le envia sus aguas.)

$\mathrm{C}_{\mathrm{ANAL}}$, es una abertura practicada en el terreno por la mano del hombre, en la que se introduce agua destinada á fines diversos; cuando es para recibir embarcaciones se llama CANAL DE NAVEGACIÓN; si es para transportar agua á otros lugares secos, CANAL DE RIEGO; y CANAL DE DESECACIÓN ó DE SALUBRIDAD, si tiene por objeto desecar los pantanos.

Sucede á veces que en el curso de un río ó arroyo se presentan precipicios más ó menos profundos; en tal caso, y si la caida es de un río, se denomina Catarata; Salto cuando es de menor importancia, y RAUDA si la caida es de un arroyo. El Paraguay posee uno de los mas importantes saltos: el Guairá en el río Paraná y el Aguaray en el río del mismo nombre. 


\section{PRIMERA PARTE.}

\section{Origen del nombre Paraguay.}

Los historiadores discrepan respecto al verdadero orígen del nombre Paraguay; una de las versiones más generalizada es, que al descubrimiento de esta región de América, los carios, que habitaban la costa Oriental del río le llamaban PAYAGUá-í, que equivale à decir AGUA DE LOS PAYAGUÁs, por que estos indios navegaban privativamente su cur'so desde la laguna de los XARÁYES hasta más abajo del Colastiné que desagua en el río Paraná.

Posteriormente y de manera inexplicable, debe haberse cambiado la $\mathrm{Y}$ y la $\mathrm{I}$, por la $\mathrm{R}$ y la $\mathrm{Y}$ respectivameute y se obtuvo así la palabra Paraguay.

Otra versión, que se reputa más exacta, es la que le asigna el nombre de rio coronado, compuesto de Paraguá que significa "corona de palmas» é í-agua ó río.

\section{Preliminares.}

Situación geográfica. - La República del Paraguay está situada en el centro de la América Meridional, entre el Brasil, la Argentina y Bolivia.

Longitud y latitud. - Su posición astronómica es entre los $17^{\circ} 25^{\prime}$ y $27^{\circ} 31^{\prime}$ de latitud Sur y $3^{\circ} 35^{\prime}$ de longitud Oriental y $4^{\circ} 46^{\prime}$ de longitud Occidental del meridiano de Asunción.

Límites generales. (1) - Al Norte Bolivia y Brasil; con la

(1) Apéndice 1. 
primera, por el río Negro, el curso del río Otuquis y la cordillera de Chochis; y con el segundo, por el río Apa, el arroyo Estrella (1) y la cordillera de Mbaracayú.

Al Sur, la Argentina, por el río Paraná.

Al Este, Brasil, por el río Paraguay, la cordillera de Amambay y el río Paraná.

Al Oeste, Bolivia y la Argentina; con la primera por el río Parapití, una línea terrestre y el río Pilcomayo, y con la segunda, por el río Paraguay.

Al Suroeste, la Argentina, también por el río Pilcomayo.

Configuración. - Su configuración es la de un polígono irregular de muchos lados, cuyos ángulos, siguiendo de derecha á izquierda, se hallan determinados por la boca del río Negro, cerro Concepción, extremo de la línea terrestre que llega al río Pilcomayo, desembocadura de este río, la unión de los ríos Paraguay y Paraná, la ciudad de Villa Encarnación, el Salto de Guairá, el vértice formado por las Cordilleras de Mbaracayú y Amambay, Punta Pora y la desembocadura del Río Apa.

Perímetro. - Su perímetro es de 3.627 kilómetros, de los cuales unos 2.892 son de costas fluviales y los 735 restantes, de línea terrestre.

Superficie.-Aproximadamente 445.000 kilómetros cuadrados.

Costas. - Las más extensas son las del río Paraguay, que comprendidas ambas costas en la parte que cruza por el territorio paraguayo, alcanzan á unos 1.440 kilómetros; las del Paraná, no menores de 800; sobre el Pilcomayo, 800; en el río Parapití, 250; sobre el Apa, 200; en los ríos Negro y Otuquis, 200; y 90 en el arroyo Estrella; total: 3.780 kilómetros.

Población. - 700.000 habitantes.

División natural. - El río Paraguay divide el territorio paraguayo en dos grandes REgIONEs: una Oriental y otra Occidental.

(1) Apéndice 2. 


\section{Región Oriental.}

\section{Preliminares.}

Límites. - Al Norte, el río Apa y el arroyo Estrella que la separa del Estado brasileño de Matto-Grosso; al Este, las cordilleras de Amambay y el río Paraná que la divide y separa también del Brasil (Estado de Paraná) y la Gobernación argentina de Misiones; al Sud, el mismo río Paraná que la limita de la Provincia de Corrientes (R. A.) y al Oeste, el río Paraguay que la separa de esta última República (Gobernaciones de Formosa y del Chaco) y de la Región Occidental del Paraguay.

Perímetro. - Su perímetro es de 2.090 kilómetros, de los cuales unos 1800 son de costas fluviales y los 290 restantes, de línea terrestre.

Superficie. - 168.000 kilómetros cuadrados aproximadamente.

Costas.-Las más extensas son las del río Paraná que alcanzan á unos 800 kilómetros; sobre el río Paraguay, 710; las del río Apa 200; y 90 en el arroyo Estrella: total 1800 kilómetros.

Aspecto general. - La región Oriental es de variado y hermoso aspecto; limitada en el Este por las cordilleras de Amambay y Mbaracayú, cuyas ramificaciones se extienden en diferentes direcciones, dando lugar á la formación de hermosos valles surcados por ríos y arroyos; es un suelo feraz.

En esta región abundan los campos de pastoreo en que se crian millares de cabezas de ganado vacuno, multiplicándose con suma rapidez, y bosques ricos de maderas de construcción y ebanisteria, perteneciendo una gran parte al árbol de yerba-mate beneficiado desde la época de la conquista, y un sin número de plantas frutales, medicinales, textiles, etc., que, explotados, constituirán fuentes de recursos para las industrias.

Población. -675.000 habitantes.

Decoud, Geografía. 


\section{Descripción física.}

I.

\section{Orografía.}

Sistema orográfico.-Las Cordilleras de Amambay y MbaRACAYÚ, que son cadenas del gran sistema brasileño, constituyen el sistema orográfico de la región Oriental de la República del Paraguay.

La cordillera de Amambay, que forma parte el límite oriental del Paraguay, se extiende desde la naciente del arroyo Estrella hasta unos 190 kilómetros, de cuyo extremo, bajo un ángulo casi recto, sigue en dirección al Este la cordillera de Mbaracayú, cruza el río Paraná formando el Salto de Guatrá y se interna en territorio brasileño, marcando también el límite septentrional paraguayo.

Las cumbres más elevadas de la cordillera de Amambay, siguiendo de Norte á Sur, son: Punta Porá (650 mts.), Mangrullo, (540 mts.), y Yaguarundy (420 mts.).

Sistema de Amambay. - La cordillera de Amambay, desprende un ramal de Punta Porá en dirección al occidente con el nombre de Sierra de las 15 Puntas y después de haberse ramificado á uno y otro lado, llega al río Paraguay formando sobre sus márgenes el grupo de CERros DE Itapucú-guazú. Al Sur de estos y cerca de la colonia Risso, se encuentran los cerros de Peña Hermosa. De aquí sigue al Sur la costa de piedra, en una extensión de 6 kilómetros, con el nombre de Piedras Partidas que es el remate de otro grupo aislado de colinas. Y finalmente, 
más al Sur aún, se encuentra Itapucú-mi, que remata otro grupo de colinas sin conexión aparente con las anteriores.

La Sierra de las 15 Puntas atraviesa los partidos de Pedro Juan Caballero, Bella Vista y Villa Concepción.

Sistema de Mbaracayú.-Este sistema es más importante que el anterior por que de él se bifurca la CoRdillera de CaAguazú que se prolonga al Sur y Oeste esparciendo numerosas ramificaciones.

La cordillera de Caaguazú nace del ángulo formado por los dos sistemas; se dirige primeramente al Sureste y luego al Sur cruzando los partidos de San Joaquín, Ihú, Carayaó, Caaguazú, Villa Rica, Caazapá, San Juan Nepomuceno, Yegros, Yutí, San Pedro del Paraná, Bobí, Jesús y Trinidad y termina en Villa Encarnación. Esta cordillera no es una masa continua, pues se halla interrumpida con frecuencia en cerros y barras aisladas á medida que se aparta de su nudo.

De los diferentes ramales secundarios que se desprenden de la cordillera de Caaguazú, hay uno que, de las cercanías de Villa Rica, se dirige al occidente con el nombre de CoRDILLERA DE Ibituruzú, en su comienzo y luego con el de CoRdillera DE LOS Autos, atraviesa los partidos que se encuentran sobre esta última hasta el de Emboscada sobre el río Paraguay, puerto de Arecutacuá.

Las cordilleras de Ibituruzú y de los Altos, desprenden á su vez diferentes ramales al Norte y Sur, siendo los más importantes los CERROS DE IBITIMí que tienen su origen en el partido de su nombre y se prolongan en barras y cerros aislados hasta Villeta, y los cerros DE IBItIPané, que de Paraguarí se dirigen al occidente formando el pintoresco valle de Pirayú é Ipacaray, y termina en Lambaré á 5 kilómetros Sur de Asunción.

Cerros.-Los principales cerros que existen, ya sean con base en los sistemas descritos ó ya aisladoś, son: los de VILLA RICA (680 mts.), Acahay (585 mts), Ibicui, CaApucú, San Miguel, 
Santa Rosa, San Ignacio, Paraguarí y Yaguarón, cuya altitud mayor sobre el nivel del mar no pasan de 700 metros. Por lo general las cumbres de estos cerros son de forma cónica y cubiertas de vegetación.

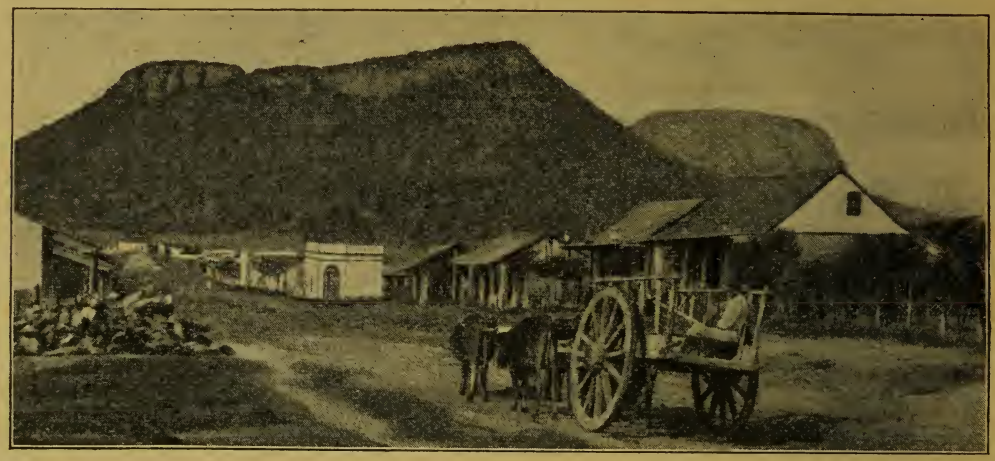

Cerros de Paraguarí.

Grutas.-La más notable es la del Cerro de Santo Tomás en el partido de Paraguarí que se encuentra á unos 256 metros de altura.

Esta gruta es de forma cuadrilonga cubierta por una mole de piedra plana. Mide 24 metros de largo, 4 de ancho y 6 de alto.

II.

\section{Hidrografía.}

Sistema hidrográfico.-El sistema orográfico descrito es el que principalmente dá origen á la formación de los ríos y arroyos de la región Oriental del Paraguay, que no bajan de ochocientos, siendo la mayor parte de ellos, tributarios de los grandes y caudalosos ríos Paraguay y Paraná.

Río Paraguay.-De As Sete Lagoas del Estado de MattoGrosso (Brasil), se forma el río Paraguay. Consta en un principio de dos brazos, el río Curabá y el río Paragday-mí, que se dirigen, al comienzo, de Noreste á Suroeste y luego se inclinan 
insensiblemente al Sur hasta juntarse en los pantanos de los Xarayes. De aquí con el nombre de Paraguay toma la dirección general de Norte á Sur, y en menos de la mitad de su curso comienza à recorrer la región Occidental, desde la boca del río Negro hasta la del río Apa; de aquí atraviesa ambas regiones hasta la desembocadura del río Pilcomayo y por último, desde aquí recorre también la región Oriental, hasta su unión con el Paraná. Sirve de límite con la Argentina en esta última sección y con los Estados Unidos del Brasil, en la primera.

El río Paraguay es uno de los más importantes de la América del Sud, tanto por la regularidad de su curso y la facilidad que por consiguiente ofrece á la navegación, como porque penetrando, por decir así, en el corazón mismo del Continente Meridional y regando con sus aguas y las de sus afluentes tres Estados limítrofes, sirve de vínculo de unión comercial para el intércambio de sus productos por el Paraná y el Plata á las diversas plazas mercantiles de estos pueblos y hasta la misma Europa.

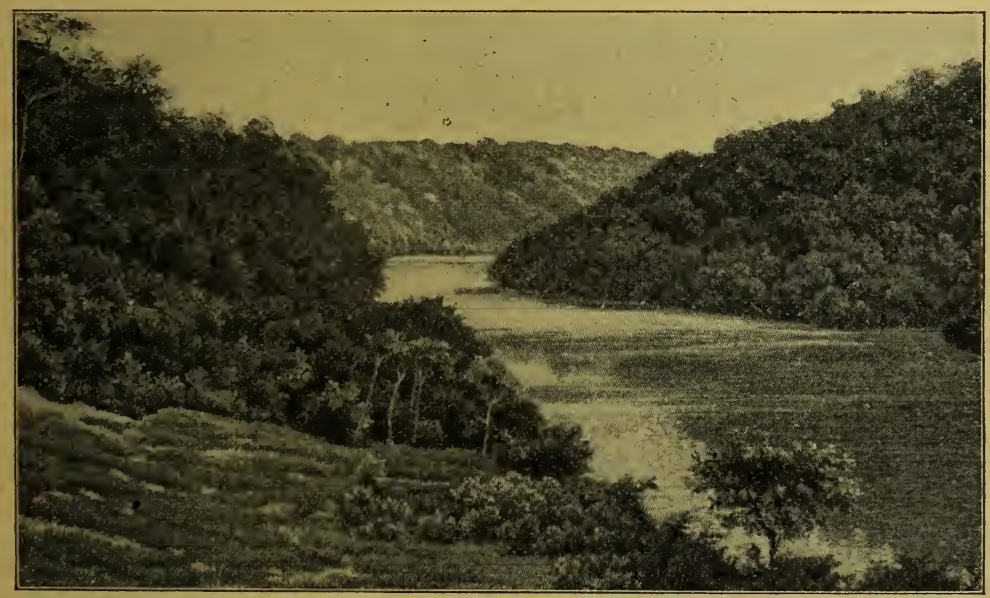

Rio Paraguay.

El río Paraguay en su curso por la frontera y centro del territorio de su nombre, tiene una anchura media de 500 metros y una profundidad de 4 á 5 metros. Buques de porte remontan en él hasta Corumbá, 200 kilómetros arriba de Bahía Negra en 
la desembocadura del río Negro. Su extensión es de 1500 kilómetros, de los cuales, como queda dicho, sólo un poco más de la mitad surca con sus aguas las fértiles y deliciosas zonas de la región Occidental y Oriental.

La corriente es de 3 kilómetros por hora en una pendiente que no baja de cincuenta centímetros por mil metros.

En las bajantes anuales hay pasos, como el de Angostura á 42 kilómetros de la Asunción, en que el río tiene apenas una profundidad de 1.50 metros. Los buques se ven obligados á estacionarse allí y trasbordar sus pasajeros y carga en embarcaciones de menor calado, para llegar á su destino.

La diferencia del nivel del río Paraguay en su máxima y mínima altura, es de 3 metros, como término medio. En las crecientes extraordinarias, como la del año 1905 , no pasó de 7 metros.

Las IsLas mas importantes del río Paraguay en su curso por el territorio de su nombre, siguiendo de Norte á Sur, son: la Itacurubí, entre la desembocadura del río Aquidaban y la Villa Concepción; la Vilua Concepción, frente á la ciudad de su nombre; la Payaguá-Tupaó (1) frente á Olivares y la San FrancIsco, casi frente á Villa Hayes.

Peñón.-El peñón mas notable que existe en el río Paraguay, es el que se encuentra á 5 kilómetros al norte de Villa Hayes y que puede considerarse como uno de los remates de la cordillera de los Altos.

Afluentes.-Los principales tributarios del río Paraguay que proceden del territorio de su nombre, por la márgen derecha y siguiendo de Norte á Sur, son: el río Negro, el Gábán, el Aguaray-Guazú, el Verde, el Confuso y el Pilcomayo que se describirán al hablar de la región Occidental y por la izquierda, los ríos Apa, aquidaban, Ipané, Jejuí, Manduvirá, Piribebuy, Salado, Tebicuary y otros.

Río Apa. - Se forma de un sin número de arroyuelos que nacen en la cordillera de Amambay; corre primeramente al Suro- 
este hasta unirse con el arroyo Estrella y luego recto al Oeste hasta desaguar en dos brazos en el río Paraguay. Su curso es de 260 kilómetros aproximadamente, de los cuales unos 200, ó sea la parte comprendida entre ambas barras, surca con sus aguas el territorio paraguayo y marca los límites con el Estado de MattoGrosso (Brasil). No es navegable á causa de ser poco profundo y estar obstruido su curso de arrecifes, siendo los más notables el Quien vive, por su gran altura, y el San Antonio, por su extensión y hallarse formado de grandes piedras de granito.

En la última extensión se encuentra, como á 1.000 metros de la orilla paraguaya, el antiguo fortin SAN CárLos, de mampostería, construido bajo el régimen colonial.

El AFLUENTE mas importante del río Apa en su margen izquierda, es el arroyo Estrelda, que tiene su origen en un pequeño manantial que se encuentra en la misma cordillera de Amambay, á 340 metros Suroeste del mojón que divide lo más alto de esta cordillera; se dirige primeramente al Noroeste hasta recibir, por la margen derecha, el tributo del arroyo SALTo, y luego al Oeste hasta desembocar en el Apa verdadero á 3300 metros Noreste del paso paraguayo de Bella Vista. Su extensión es de unos 60 kilómetros y fija también el límite con el Estado de Matto-Grosso.

Los demas aFLuentes paraguayos del río Apa por su margen izquierda, siguiendo de Este á Oeste, son: los arroyos Sirena, Hermoso, Itaqui, Quien Sabe, Toro Paso y Carumbé; y brasileros, por la derecha, los ríos Pedra da CaL y Descaluado y arroyos Araujo y Pizarro.

Río Aquidabán.-Tiene también sus fuentes en las faldas Occidentales de la cordillera de Amambay, encontrándose la principal de ellas á 1350 metros Sureste del mojón que marca la naciente del arroyo Estrella. Desde su origen, describe un semicírculo hacia el Suroeste hasta recibir las aguas del arroyo Negla por la. margen derecha y luego corre al Oeste hasta su desembocadura en el río Paraguay, á 30 kilómetros Norte de la ciudad de Villa Concepción. La extensión del Aquidabán es de unos 260 kilómetros. 
Río Ipané. - Nace igualmente en las faldas de la cordillera de Amambay, al Sur del Aquidaban; corre casi paralelo á este y desagua en el río Paraguay á 6 kilómetros Sur de la ciudad de Villa Concepción. En su curso, que no baja de 273 kilómetros, recibe afluentes importantes como el arroyo Guazú, por la izquierda. Cruza el trópico de Capricornio al Sur de Belen.

Río Jejui. - Es uno de los mas importantes ríos que riegan el Norte de la región Oriental, por que no solamente es navegable en grande extensión, sinó que algunos de sus afluentes como el Capiybary y AGUaray-Guazú, participan de esta ventaja, constituyendo una de las principales arterías de comunicación fluvial entre las zonas que recorre.

El Jejuí se forma de dos brazos: el JeJuí-mí y el JeJuíGUAZÚ, que tienen su origen en las cordilleras de Mbaracayú y Caaguazú. Desde la unión de ambos, cerca del pueblo de Igatimi, lleva el nombre de JEJuí y con un curso más ó menos sinuoso de 180 kilómetros, corre generalmente al Oeste y desemboca como los anteriores en el río Paraguay.

Río Manduvirá. - Tiene su nacimiento en las faldas septentrionales de la cordillera de los Altos con el nombre de IнAGür; se dirige primeramente al Norte hasta el paralelo de Caraguatay y luego al Oeste, atravesando terrenos fértiles y desemboca en el río Paraguay con el nombre de Manduvirá, después de haber descripto un trayecto de 100 kilómetros. Entre los numerosos afluentes que recibe, el IHú es el más notable.

Río Salado. - Se forma del lago Ipacaraí, corre en dirección al Oeste y desemboca en el río Paraguay frente al peñon. Su curso no pasa de 28 kilómetros.

Río Tebicuary.-Este río es uno de los más grandes y caudalosos afluentes del río Paraguay. Cruza casi por completo de Este á Oeste la parte meridional de la región Oriental. Nace en las faldas occidentales de la cordillera de Caaguazú, corre hacia el Sureste aumentado con las aguas de muchos arroyos, hasta Yuty; de allí sigue generalmente al Oeste hasta su desem- 
bocadura, presentando en esta parte una anchura de 230 metros. $\mathrm{Su}$ curso es de 235 kilómetros, inclusive las curvas principales.

Río Paraná. - Cerca de la ciudad brasileña de Goyaz nace el río Corunbá que unido más al Sur con los ríos Paranahyba y Grande, toma el río resultante el nombre de Paraná. Se dirige al principio de Noreste á Suroeste y luego insensiblemente al Sur. Atraviesa la sierra de Mbaracayú y forma el gran SALTO DE Guatrá, desde donde comienza el límite con el Brasil.

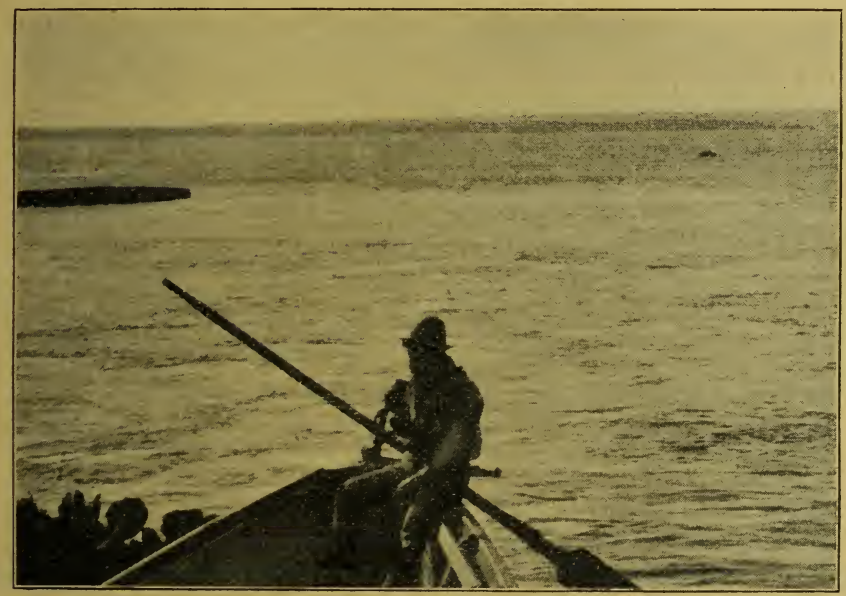

Rio Paraná.

De aquí, entre elevadas barrancas hasta de 20 metros, cubiertas de una asombrosa vegetación, sigue la misma dirección hasta cerca de la ciudad de Villa Encarnación, para luego cambiar bruscamente su curso y dirigirse netamente al Oeste por terrenos bajos y con escasa vegetación á unirse con el río Paraguay, que es el estremo del límite paraguayo.

Aumentado así considerablemente el caudal de sus aguas con este poderoso afluente, corre por territorio argentino con el mismo nombre de Paraní, hasta desembocar en varios brazos en el Plata. Su extensión es de cerca de 4.5000 kilómetros, de los 


\section{$-\quad 26$}

cuales no excede de 800 los que bañan los partidos de Villa Igatimí, Villa Curuguaty, Jesús y Trinidad, Villa Encarnación, Carmen del Paraná, San Cosme, Santiago, Ayolas, Yabebiry, Laureles, Desmochados, Pedro González y Paso de Patria.

El Paraná, en su curso por la frontera paraguaya, no siempre guarda igual anchura, pues ésta viene progresivamente aumentando desde el Salto de Guairá hasta su unión con el Paraguay, al extremo de no pasar de 50 metros en el primer punto, mientras que en las proximidades de Villa Encarnación alcanza á 700 metros y en el Paso de Patria no baja de 3.200 metros. La velocidad de su corriente es de $4 \frac{1}{2}$ kilómetros por hora y su profundidad media en tiempos normales, de 4 metros. Desde unos 100 kilómetros abajo del Salto de Guairá, hasta los de AÑACUÁ y APIPÉ, es navegable por buques de pequeño calado y más adelante, sin interrupción alguna, por buques de porte.

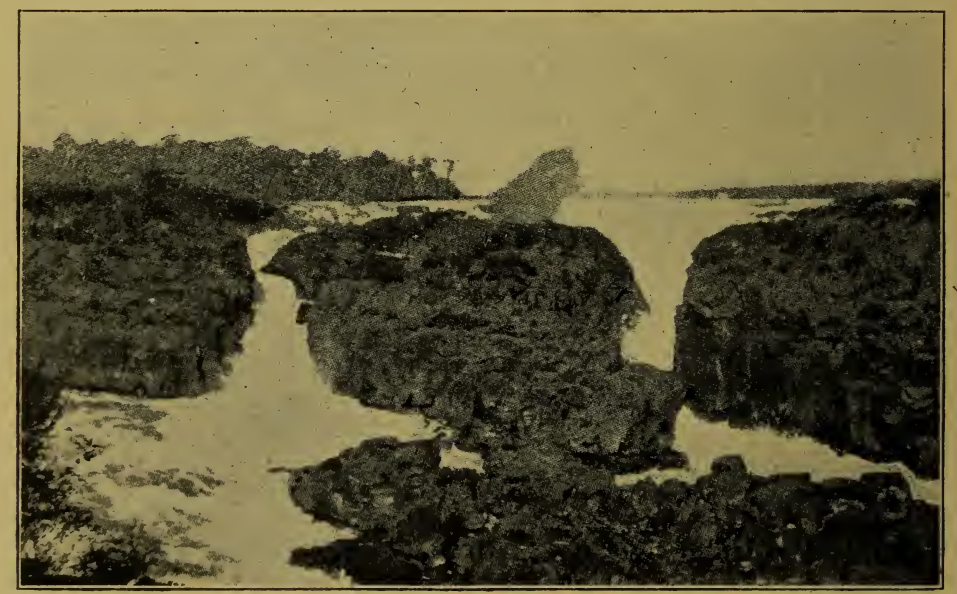

Salto de Guairá.

Entre los numerosos Saltos que existen en el río Paraná en su curso por la República, es notable el GuaIRÁ, conocido antiguamente por Canendiyú (1), que se encuentra bajo del Trópico.

(1) Apéndice 4. 
Es una de las cataratas más hermosas que se pueden admirar. Las aguas del Paraná, un poco más arriba de donde la cordillera de Mbaracayú interrumpe el paso de sus aguas, se ensancha en forma de un dilatado lago sobre una meseta formada de las ramificaciones de la cordillera de Mbaracayú, sobre cuya falda, cortada á pico y en una extensión semicircular de 4300 metros, se desploman por distintas partes cortinas de agua convertidas en una inmensa masa que se precipita con rapidez y turbulencia atronadora hacia un centro de convergencia de 60 metros; las aguas agitadas se estrellan entre las rocas y se levantan encrespadas, haciendo un ruido ensordecedor, á la altura de 6 metros, desprendiéndose de ellas un rocío ténue que mantiene una auréola de nubes perceptible á gran distancia. Embravecida así la corriente, se lanza á un precipicio de 17 metros produciéndose así el gran Salto, ante cuya magestad se extasía el espíritu y llega á palpar con los sentidos el grandioso poder de la Naturaleza.

De las ISLas más importantes del río Paraná, merece mencionarse la Yasiretá que pertenece á la República del Paraguay, con terrenos elevados, campiñas y florestas alternadas de magestuosos árboles y adecuada especialmente para la cria de ganados. Tiene una superficie de 461 kilómetros cuadrados y sus extremos dan frente á los pueblos de San Cosme, al Este y al puerto de San José-mi en Ayolas, al Oeste.

Los AFLUENTES paraguayos por la ribera occidental, siguiendo su curso, son: el río Pelotas, Igurei, Pozuelos, Itambey, Santa Teresa, Acaray, Monday, Gürrapey y Tacuarí y una infinidad de arroyos que no bajan de 200. En la margen izquierda tiene también afluentes brasileños y argentinos come el Río Grande de Curutibá ó Iguazú, que fija los límites entre estos dos estados.

Río Acaray.-Tiene sus fuentes en la cordillera de Caaguazú; empieza su curso al Sur hasta recorrer unos 150 kilómetros de Oeste á Este y desagua en el Paraná, recibiendo las aguas de numerosos tributarios como el río Iguazú y otros.

Rio Monday.-Se forma de la reunión de muchos arroyos que 
tienen su origen en la misma cordillera de Caaguazú al Sur del anterior; cruza al Norte de este pueblo con el nombre de GüyRAUngú́, corre generalmente al Este y desemboca en el Paraná con el nombre de Monday. Su extensión no baja de 165 kilómetros.

En medio de la caida de estos dos últimos ríos desemboca de la banda opuesta, el rio Iguazú, que como queda dicho divide el territorio brasileño del argentino.

Río Tacuari.-Nace en el cerro San Rafael al Este de Yuti y después de un trayecto de 80 kilómetros, desemboca como los anteriores, en el Paraná; en su curso superior corre de Noreste á Suroeste con el nombre de Tucuaruzú y luego al sur con el de Tacuarí hasta su desembocadura. Cruza en esta última sección, el paso de Del Carmen, célebre por la capitulación del general argentino Manuel Belgrano en 1811.

Lagos.-Los LAGos existentes en esta región son de dos clases; permanentes y transitorios. Los primeros están alimentados por las aguas que vierten en su lecho los ríos y arroyos, tales como el Ipoá y el Ipacaraí y los segundos, simples receptáculos de aguas llovedizas, como los esteros de Aguará-catí, ÑEembucú etc.

Lago Ipoá.-Se encuentra al Sur de la Asunción y á unos 45 kilómetros del río Paraguay; presenta una forma oval de Norte á Sur, rodeado de inmensos bañados, cuya circunstancia lo hace casi inaccesible, especialmente en la época de las crecientes de los ríos y arroyos que lo circundan. El Ipoá recibe las aguas de muchas vertientes y dá origen á otros tantos que, como el río Negro en el Tebicuary, aumenta el caudal del río Paraguay.

Lago Ipacarai. (1) - Ofrece pintoresco aspecto, rodeado al Norte por la cordillera de los Altos y al Sur por los cerros de Ibitipané. Su extensión es de 22 kilómetros de Este á Oeste, por 5 kilómetros en la parte más ancha, ofreciendo en ciertos

(1) Apéndice 5. 


\section{$-29$}

puntos bastante profundidad para la comunicación establecida entre los pueblos que lo rodean, por medio de pequeñas embarcaciones que lo cruzan diariamente.

Los baños del Ipacaraí se reputan saludables y muchos viajeros lo frecuentan en la estación templada.

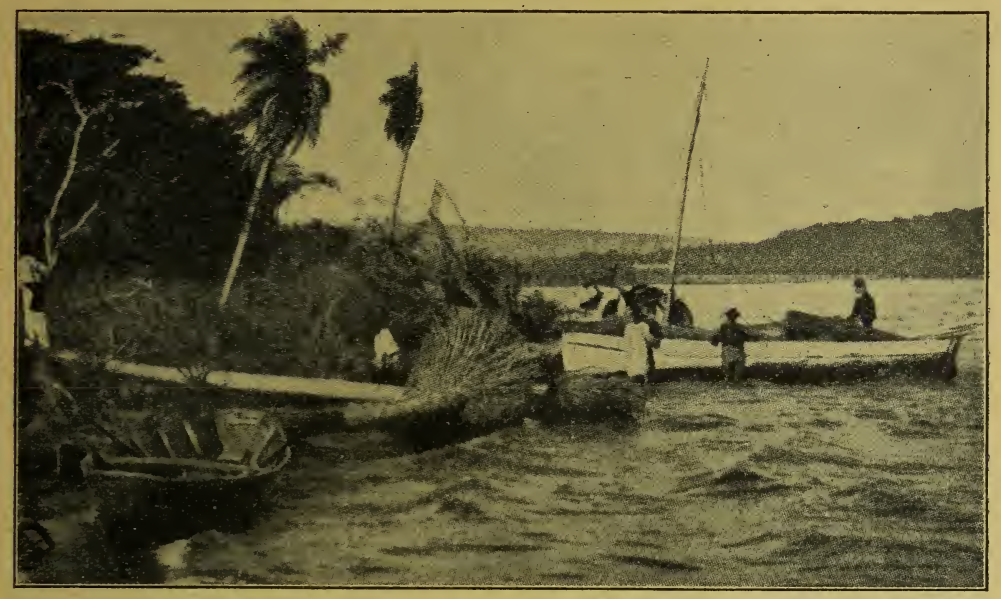

Lago Ipacaraí.

Navegabilidad de los ríos. - La mayor parte de los ríos y de sus tributarios nombrados son navegables en grande extensión de su curso, sirviendo los primeros para los buques de mucho porte y los segundos para el cabotaje. Muchos de los ríos y arroyos se prestarían á ser navegables, si sus corrientes no estuviesen obstruidas por los bancos de aluviones y restos de árboles caidos en su curso.

\section{III.}

\section{Suelo.}

Naturaleza geológica. - La naturaleza geológica de los terrenos inferiores de la región Oriental puede clasificarse: $1^{\circ}$, en capas de rocas de época plutoriana, compuestas de granitos que 
por la acción del fuego se han levantado en algunos puntos, constituyendo las cumbres de las cordilleras; $2^{\circ}$, en terrenos sedimentarios colocados sobre la capa anterior que deben su origen á materiales que han trasportado y depositado las aguas con la acción lenta y progresiva de los siglos. La parte exterior de esta última capa, llamada Husus, está formada por los detritus de los vegetales, y se caracteriza por la presencia de restos de vida orgánica, vegetales, y minerales, que se denominan FósıLes.

Clases de terrenos.-La tierra laborable abraza todo el suelo exterior del territorio, y puede clasificarse en TIERRAS FUERTES, difíciles de labrar, y en tIERRAS LIGERAS, aptas para el cultivo por contener gran cantidad de sustancias minerales, vegetales y animales. Ambas tierras se encuentran cubiertas de gramíneas que alimentan á todos los ganados.

Terrenos pantanosos. - Existen extensas zonas cubiertas de pantanos, siendo los más considerables los de Estero Bellaco en que se libró, contra el Ejército Aliado, la memorable batalla campal del 2 de Mayo de 1866, los de Ñeembucú, Ypoá y Aguaracatí.

Riqueza mineral. - Entre la riqueza mineral que contiene el suelo paraguayo y que ha sido estudiada, figura en primer término: de los metales, el HIERro (1) que abunda en gran parte de la región Oriental, principalmente entre los ríos Apa y Aquidaban, y los partidos de Quiquió, Ibicuí, Caapucú y San Miguel; el MANGANESO, en gran abundancia en la cordillera de Ibicuí; y el совRe, en Villa Encarnación. Preténdese también que hay MERCURio en San Miguel, ziNc en la Cordillera, y que así mismo se ha encontrado oro en Acahay. (2)

El hierro es el único metal que ha sido explotado en el Paraguay, habiendo producido el de Quiquió é Ibicuí hasta el $34 \%$ de hierro puro.

Entre las sustancias terrosas y pétreas, se encuentran, para la construcción: las CALCÁREAS, en Itapucú-mi, la CAL HIDRÁULICA,

(1) Apéndice 6 .
(2) Apéndice 7 . 
en Peña Hermosa, los esquistos arcillosos duros y arcillo CaLCáreos, en Paraguarí, Cerros Morados, Curuguaty é Ibitimí, los basaltos (itá-jhú), granitos y traqutos, en Lambaré, Luque, Areguá, Acahay é Itapé; para adornos, los Mármoles, en Itapucúguazú, Itapucú-mí y Piedras Partidas, los pórfidos, el cuarzo hialino, las ágatas, las calcedontas y ópalos, en Paraguarí é Ihacanguazú; y para la industria, las GREDAS y ESqUISTOS ARCILLOSOS, para piedras de amolar; la ARENA BLANCA, para vidriera; las ARCILLAS (ñayhú, lodo é yby-pytá) para locería y ladrillería en casi todos los partidos; el caolin (tobatí) (1), para porcelana, en Yhú y Quiquió; las arcillas aCrosas, para la pintura, en los Cerros Morados y Caaguazú; el yeso en Villa Franca; y la saL conúx (2) en Lambaré, Luque, Areguá, Ipané y otros.

Canteras. - Existen muchas en esta región, pero en el dia sólo se explota la piedra-loza del partido de Emboscada y la cal de Villa Concepción, sobre el río Paraguay. También comienza á explotarse piedra-loza de Areguá, Paraguarí y Villa Rica, pero de inferior calidad á la de Emboscada.

\section{IV.}

\section{Clima.}

La región Oriental, por su posición geográfica, pertenece á la zona templada y tórrida y goza de un clima suave y saludable, hasta el punto que la Asunción, de algún tiempo á esta parte, es, en el invierno, lugar de cita obligado para viajeros y familias acomodadas de las capitales vecinas, que afluyen atraidas por su dulce temperatura.

La circunstancia de que la parte Norte y Este del país se encuentra cubierta de cordilleras y grandes bosques y que la del Sur sea baja y húmeda, establece una diversidad de aspecto topo- 
gráfico, y la consiguiente influencia en las manifestaciones climatéricas, que determinan condiciones que se traducen en variaciones térmicas.

La influencia de las lluvias, que de una manera desigual riegan el territorio, es también una de las causas de esa diversidad. Es así que esta región presenta dos fases distintas: una al Norte del río Jejuí y otra al Sur. La primera por su posición alta, correspondiente á la línea tropical del Capricornio, recibe en verano grandes lluvias torrenciales que producen variaciones notables en la temperatura. Durante el día, á las 2 p. m., el termómetro generalmente señala de $37^{\circ}$ á $38^{\circ} \mathrm{C}$., y de noche, el aire saturado por abundantes vapores de agua, produce un copioso rocío que lo hace descender á $18^{\circ}$. Estas variaciones no son perjudiciales á la salud, como sucede en otros puntos del globo, porque la zona donde se producen es generalmente alta y cubierta de vegetación; mientras que en la segunda región, ó sea en la parte Sur, esas variaciones no son tan sensibles, á pesar de que á ellas se encuentra sometido todo el país, especialmente en los meses de Junio, Julio y Agosto y muchas veces hasta Septiembre. En el trascurso de cuatro horas, la temperatura experimenta un descenso rápido, que llega á veces á una diferencia de $15^{\circ} \mathrm{C}$.

LA TEMPERATURA media del año varía en la Asunción entre $22^{\circ}$ y $23^{\circ}$ C., siendo el interior de la República más fresco $\left(17^{\circ}\right.$ á $\left.22^{\circ}\right)$.

El límite máximo de la temperatura observada en la Asunción es de $41^{\circ}$, debiendo observarse que pasan años que no se eleva el termómetro arriba de $37^{\circ}$ y esto sólo en los meses de Diciembre, Enero y Febrero de 1 á 3 de la tarde; mientras que el mínimo varía entre $1^{\circ}$ y $4^{\circ}$ en los meses de Mayo, Junio, Julio, Agosto y á veces Septiembre, durante 4 á 5 dias y con cielo serenoso.

La diferencia entre la temperatura media del verano (Octubre á Marzo) y del invierno (Abril á Septiembre), puede considerarse de unos $6^{\circ}$. 
En 1894, el termómetro señaló en la Asunción como temperatura media, $21^{\circ} 80$ C., habiéndose observado 16 días fríos, dos en el mes de Mayo, cuatro en el de Junio, siete en el de Julio, dos en el de Agosto y uno en Septiembre; 240 días templados, y el resto de 109, calurosos la mayor parte.

Las LLuvias son muy frecuentes en todo el territorio de la República, debiendo afirmarse que no pasa un año, sin que llueva lo suficiente para favorecer á la agricultura.

LOS AGUACERos, aunque de poca duración, son también bastante frecuentes en los meses de Diciembre, Enero y Febrero de 12 m. á 4 p. m., con especialidad en la región Norte del río Jejuí.

Inmediatamente después de un aguacero, el horizonte se presenta despejado por completo, sintiéndose calor sofocante.

La media de lluvia anual caida en la Asunción durante doce años de observación, es de 1.544 milímetros.

El mes que produce más aguas es Marzo y el más seco Agosto. Como término medio cae en el primero 190 y en el segundo 56 milímetros.

El año más lluvioso fué en 1878 con 2.613 milímetros, y el más seco en 1883 , con 1.145 milímetros.

Como término medio hay ell el año 79 días de lluvia.

Colocando los meses, según las alturas pluviométricas producidas cada mes durante un período de doce años de observación en Asunción, se sigue este orden:

\begin{tabular}{|c|c|c|c|}
\hline & Milfmetros & & Milimetros \\
\hline Enero & $1 \pm 6$ & Julio & 70 \\
\hline Febrero. & $1 \pm 0$ & Agosto. & 56 \\
\hline Marzo & 190 & Septiembre & 99 \\
\hline Abril & 174 & Octubre & 162 \\
\hline Mayo & 134 & Noviembre & 135 \\
\hline Junio & 85 & Diciembre. & 153 \\
\hline
\end{tabular}

Si estas cantidades de lluvias que ascienden á 1.544 milímetros, fuesen repartidas en los días del año, correspondería á cada uno 4.23 milímetros.

La HUMEDAD relativa media, mensual, en Asunción es de 71.08 por ciento.

El cuadro siguiente hace conocer la humedad relativa durante el año 1894.

\begin{tabular}{|c|c|c|c|}
\hline Enero & $77 \%$ & Julio & $73 \%$ \\
\hline Febrero & $77 »$ & Agosto & \\
\hline Marzo. & $76 "$ & Septiembre & $62 »$ \\
\hline Abril. & $76 »$ & Octubre & $70 \%$ \\
\hline Мayo & $76 »$ & Noviembre & $68 »$ \\
\hline Junio ........ & $74 ”$ & Diciembre & $64 »$ \\
\hline
\end{tabular}


Las SECAS de consideración, son raras.

En los últimos 36 años transcurridos, se ha notado una sóla seca que duró 9 meses y terminó en Febrero de 1877. Sin embargo, debido á la gran abundancia de ríos, arroyos y lagunas permanentes que existen en la República, no hubo pérdida de ganados y pasto por carencia de agua, sino de ciertas y determinadas plantaciones.

Los vientos dominantes, son: el noRte y el sur; el primero, viene del Brasil y Bolivia y es cálido y húmedo, y el segundo, de la Argentina, frío y seco. Ambos representan dos extremos opuestos.

El viento oeste es raro.

Los vientos del norte son siempre cálidos y tienen señalada influencia sobre el sistema nervioso, determinando una acción enervante. Cuando soplan algunos días consecutivos, se carga el aire de electricidad y se produce una gran humedad, hasta que al cabo de algunos días, viene una calma y estalla un viento recio del sur acompañado de agua, que restablece por completo el equilibrio y rebaja la temperatura en pocas horas de $10^{\circ}$ á $15^{\circ}$.

Durante los días que soplan los vientos del norte, la temperatura se eleva en el verano de $35^{\circ}$ á $41^{\circ}$ algunas veces, y en el invierno hasta $26^{\circ}$.

Las tormentas reinan algunas veces en el verano y se producen por lo general acompañadas de lluvia.

Los huracanes son casi desconocidos en el Paraguay.

Entre los conocidos se encuentran dos: uno, el del 14 de Mayo de 1799, que asoló la población de Atirá, matando muchos de sus pobladores, desgajando árboles y arrastrando carretas. Otro, fué el del 8 de Septiembre del mismo año que arrojó á la playa de la Asunción ocho grandes embarcaciones. (1)

Los relámpagos son frecuentes en el verano, produciéndose ellos de tal manera, que todo el cielo parece encendido. Durante este fenómeno, de horas enteras, no se oyen los truenos.

La NIEve es completamente desconocida en el Paraguay.

Los rocíos son abundantes, especialmente desde Septiembre á Abril.

El rocío que cae al año, en los alrededores de la Asunción, no baja de 100 litros de agua por metro cuadrado de superficie.

Al Este y Sur aumenta hasta 250 litros.

(1) Apéndice 10 . 
Las HELADAS caen por lo general en los meses de Mayo á Septiembre, y no pasan, como término medio, de 10 anual.

Cuando se produce fuera de estos meses, es perjudicial para ciertas sementeras.

El Granizo es fénomeno raro; algunas veces se produce en la primavera, después de alguna tormenta, ó en el verano, después de una calma completa.

"Aunque los granizos no sean tan frecuentes como en España, una tempestad el día 7 de Octubre de 1789 , arrojó piedras hasta de dos pulgadas de diámetro, á dos leguas de Asunción.» (1)

El CIELo, en general, está más despejado que nublado en mayor número de días del año.

Pocos países del mundo tienen un cielo tan hermoso como la República del Paraguay.

De 36 ó observaciones en la Asunción, aparece:

Cielo despejado.......................... 111

" claro con $25 \%$ de nubes.................. 44

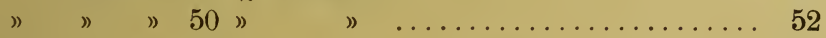

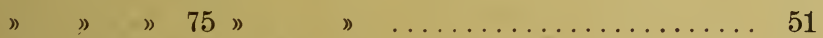

$»$ totalmente nublado $» \ldots \ldots \ldots \ldots \ldots \ldots \ldots .107$

365

V.

Flora.

Maderas de construcción y ebanisteria. - Entre las plantas indígenas de la región Oriental que forman grandes selvas, se encuentran las más finas y duras maderas de construcción y ebanistería que hay en todo el continente americano, distinguiéndose entre ellas el incorruptible uRUNDEYMí (2), cuya altura pasa de 20 metros; el quebracho colorado, como su nombre lo indica, en extremo duro que se utiliza en las construcciones en 
general; el gigantesco y estimado CEDRo, que llega hasta 30 metros de altura con 2 de diámetro en el tronco, con las mismas aplicaciones que la саова de Francia; el PETEREBy, de 25 á 30 metros de altura, empleado con preferencia en la ebanistería ; el LAPACHO (tayí) (1), cuya altura pasa de 30 metros, de tronco muy grueso, hasta de 3 metros de diámetro, útil madera para toda clase de construcciones; el guAYacán, de 12 á 15 metros de altura y de mucho peso y dureza, empleado en la ebanistería; el espinillo que se utiliza para cercos; el ybiraró, que se emplea con preferencia para masas de ruedas de vehículos; el curupay, cuya altura varía entre 20 á 25 metros, con una excelente madera para los usos generales; el LAUREL NEGRo (ayuí-jhú) de unos 15 metros, muy estimado para curvas de embarcaciones menores y sobre todo, para la ebanistería por sus variadas vetas y colores; el recto CANELón, útil para construcciones de casas en forma de tirantillos; las paLMeras, que ocupan extensas zonas, cuyas maderas dan para postes de telégrafo, tirantillos de casas y sus hojas para pantallas y sombreros; el ALGARRoBo, bastante seine-

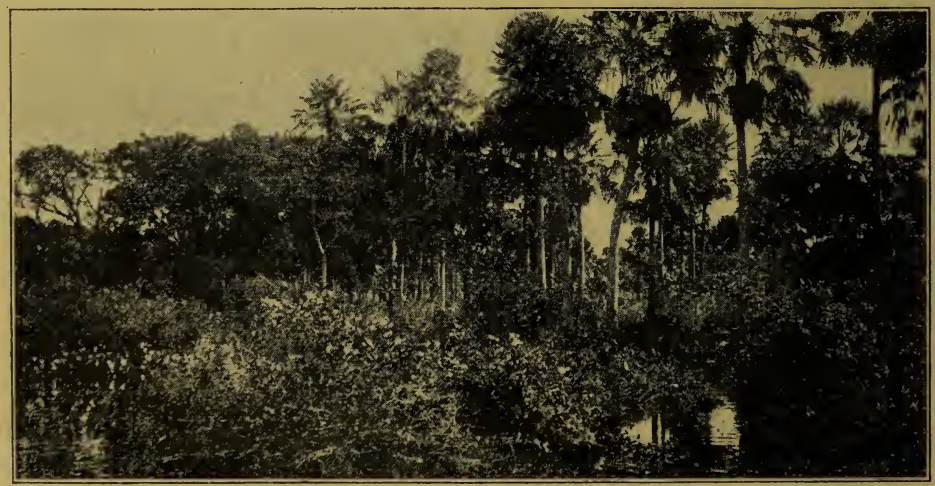

Palmar.

jante al algarrobo del Mediterráneo; el tataré, el guayaibí, el yBIŔ́-PYTÁ, el moRosibó, el paLo santo, chyo olor se parece al 
incienso, de donde proviene su nombre, el palo dE ROSA, el PALO DE LANZA, el TAPERYBÁ-GUAZÚ, el SAUCE, el elevado y derecho CURIHY y el тпмвó, que los indios trabajaban para sus canoas.

Plantas frutales.-El ÑANGAPIRY, parecido á la guinda, que se emplea en la preparación de licores; el mamón, del cual se prepara también el delicioso y estomacal LICOR DE PAPAINA; el AGUAí que sirve para dulce; el mburucurá, del tamaño de una nuez y cuya cáscara sirve también para hacer dulces; el ALGARRово, que fermentada en agua se convierte en la bebida alcohólica llamada CHICHA; el exquisito GUAVIRAmí, el GUAvirá, el GUAYABo (arazá), el YBAPOROITY, el GUAVIYÚ, el NOAGA, el INGá, el taRUMá, el YATAIBÁ, el CARAGUATá, el PACURí, el yaCARATiá, el cocotero (mbocayá), el ARAticú, el Ñandypá, el yataí, el PINDó, el MANDUVí-GUAZÚ y otros.

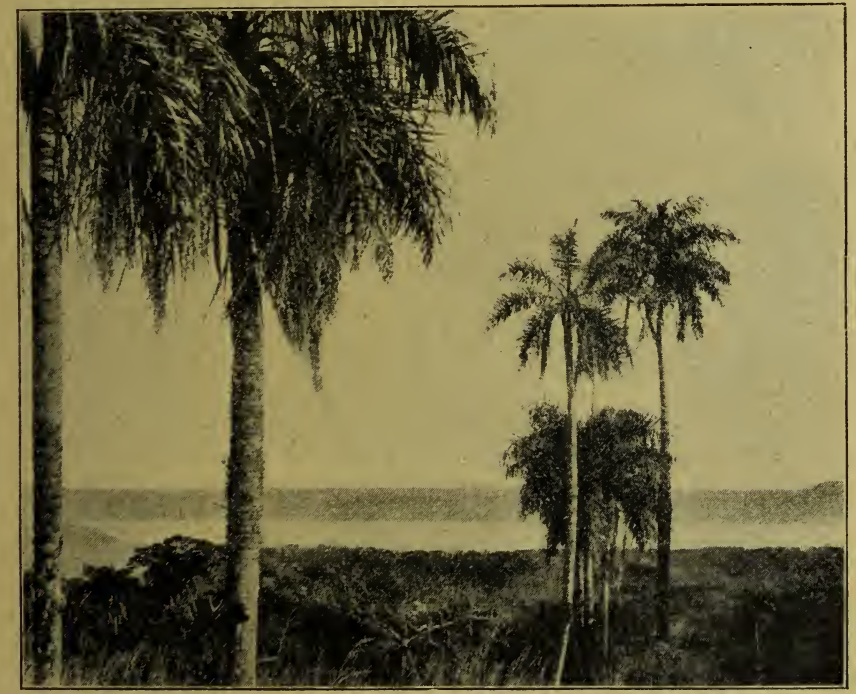

Cocoteros.

Plantas medicinales.-El aguará-rbá (fruta del zorro), de la cual se preparaba el famoso Bálsamo de las Misiones que los 
Jesuitas enviaban á España por sus grandes virtudes medicinales; el LLANTÉn, que cura las llagas; la SANGRE DE DRAGo, las heridas; la ZARZAPARRILLA, las enfermedades de la sangre; la CEPA-CABALLO, las del hígado; el YBA-Ró ó CASITA (1), la YERBA MORA (arachichú), la altaMisa, el CAÁ-verá, el CAÁ-CAMBY, el CAÁ-CATí, el CAÁCURUZÚ, el CAÁ-TAY, el CABARÁ-CAÁ (menta silvestris), el CAPIÍ-CATÍ, el CAARÉ, el CARDO SANTO, el RUIBARBo, el YBOpÉ-GUAZÚ, la MALVA, la vERDOLAGA é infinidad de otras yerbas con aplicaciones frecuentes en la medicina doméstica.

Plantas textiles. - El caraguatá, que abunda en todas partes: el yвira, el saмuHú, de cuya corteza los campesinos hacen piolas y cordeles muy resistentes; el cocotero (mbocayá), el GÜEMbÉTAYÁ, la ORTiga (pynó-guazú) y el ALGODón (mandiyú), que dá un gran rendimiento.

Plantas tintóreas.-El CAÁ-CANGaY, que dá un color ocre; el ÍNDIGo (caá-jhoby), el añil, la fruta del Ñ̉ANDYPá y las hojas del yRYBÚ-RETYMÁ, un color azul; la madera del tatayibá y del laPACHO (tayí), un amarillo; la madera del Mazaré, un color violado; y la raíz del CAÁ-CANGAY y el URUCú, encarnado.

Plantas oleoginosas. - El táktago (mbaycibó), que crece espontáneamente en todas partes y del que se saca el aceite de ricino; el cocotero (mbocayá) (2) y la copaIba (cupay).

Plantas curtibles.-Las cortezas del curupay y algarrobo y el tanino del QUEBRACHO.

Plantas gomosas.-El CAUCHO (curupicay).

Plantas forrageras. - La CEBAdILLA, el CAPIí-pé (gramilla), el CAPII-PYTÁ (paja colorada), el CAPII-Tí, el CAPIí-GUAZÚ, la FLEchilla, el fspartillo, el pasto clavel, el yajhapé, el aśdaráRUGUAY y muchas más.

(1) Apéndice 14 .

(2) Apéndice 15. 
Plantas acuáticas. - El hermoso MAIz DEL AGUA ó VICTORIA REGLA (abatí-yrupé), el CaMaLote y CaMaLOTILLO, el AGUapÉ-GUazú

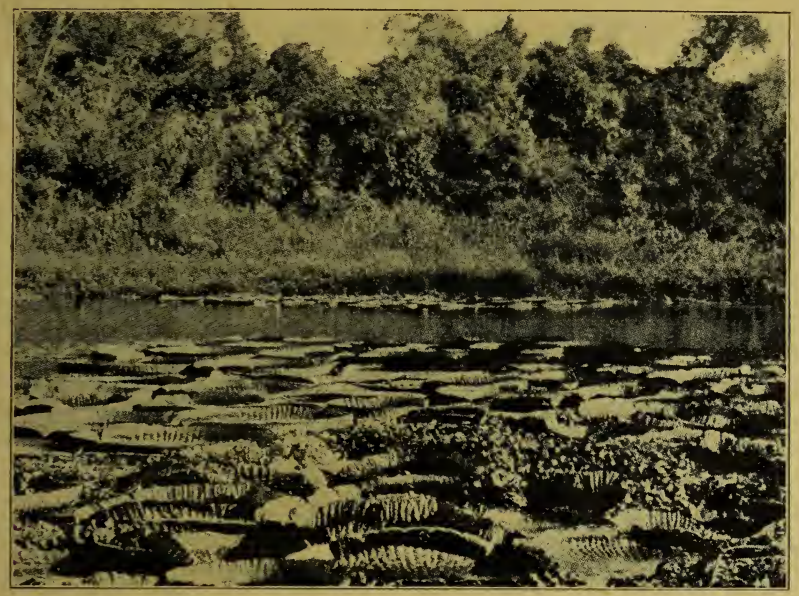

Victoria Regia.

y el AGUAPÉ-PURUHÁ, que son también forrageras, el LLANTEN DEL AGUA, el CABAYÚ-RUGUAY (cola de caballo), el PEGUAJHó, y la ESTERA (pirí).

Plantas parásitas. - El YGAU: conocido por estopa por sus filamentos delgados, el GÜEMBÉ-Pí, el CAABó-TIREY (yerba huérfana), el HIGUERón (ybá-pojhy), la FLOR DEL AIRE, el TAMANACUNá, el ANGUYÁ-RUGUAY (cola de ratón), el CAI-ABATí y otros que cubren los árboles de las selvas y palmares con sus numerosas variedades, de las que muchas dan bellísimas flores, con perfumes olorosos.

Plantas de adornos. - Los HELECHOS (amambay), los JAzMines diversos, las MaLvas, y una multitud de diferentes trepadoras conocidas por veJuco.

Plantas extractivas. - La YERBA MATE (caá) que ocupa extensas zonas del Este y Noreste de la región Oriental, calculados en unos 1.500 kilómetros cuadrados. 


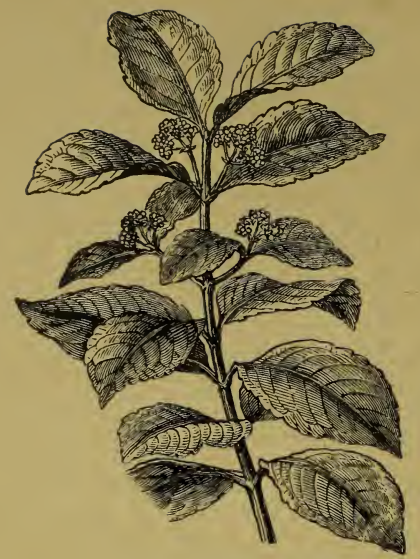

Yerba-mate (caá).

De unos años á esta parte, ha despertado gran interés el cultivo de la yerba mate. La colonia Nueva Germania, se ocupa únicamente de esta plantación.

Plantas venenosas. - También hay algunas plantas venenosas que matan á los ganados, como el мıó-мıó, el CAABÓ-POCHY y la ASUCENA que están localizadas en ciertos y determinados puntos.

Plantas exóticas. - La flora indígena va aumentando de día en día con una inmensa variedad de plantas extranjeras introducidas desde la época de la conquista, que se aclimatan fácilmente. Se cultivan, de las FRUTALES, los naranjos, durazneros, higueras, bananos, membrillos y otros; de sOMbra, el eucalíptus, la ACACIA y muchos más; MADERabLes, como álamos y pinos. Entre los CEREABles, LEGUMBres, HORTALIZAS y GRAMÍNEAS en general, las más comunes son: el maiz, el arroz, la cebada, garbanzos, porotos, maní, mandioca, papas, batata, zapallos, lechugas y otras. Y por último, entre las que son objeto de mayor cultivo, se distinguen: el tabaco, el café y la caña de azúcar.

\section{VI.}

\section{Fauna.}

\section{Animales.}

Fauna indígena. - La fauna paraguaya cuenta con una diversidad de animales de todas clases.

De los primates ó monos. - El carayá (mono aullador) que es el más grande de todos; el gracioso caí (mono) y el MIrIquixá (monito), que es el menos abundante en la región Oriental. 
De los carniceros. - El TIGRE ó JAGUAR, casi tan corpulento como el de Asia, que está representado por dos especies: el AGUARETÉ y YAGUARETÉ-POPÉ (tigre con mano extendida); el cuGUAR, que los naturales le llaman LEós, mucho menos feroz que el tigre y cada día más escaso; el YAGUARETÉ-í (gato montés) del cual hay diferentes variedades: el chIBÍGUAZÚ, el YAGUARUNDY y el EIRÁ, más pequeño de

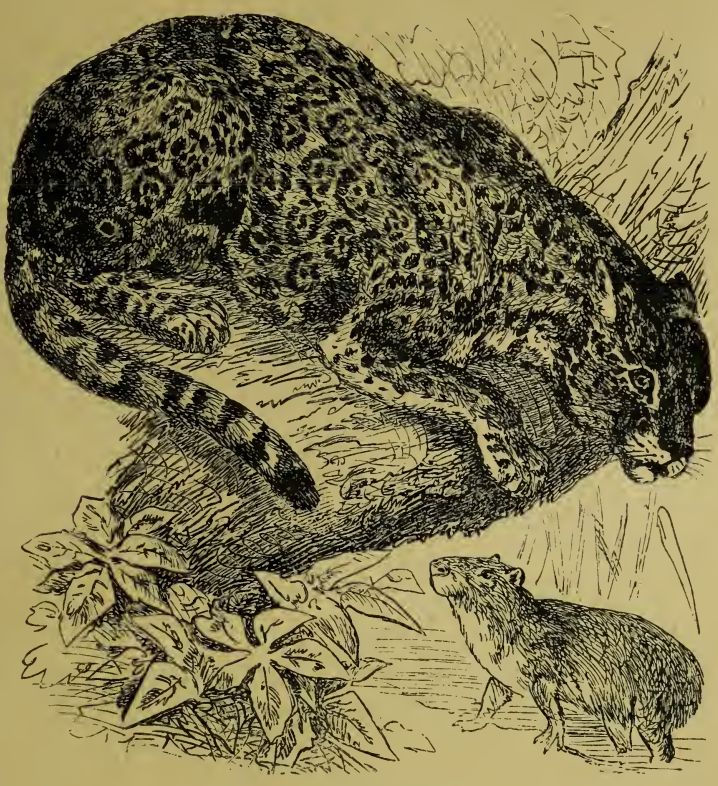

Jaguar (yaguareté). todos y de color rojizo; el zorRo, del que hay diferentes especies; el AGUARÁ-GUAzÚ

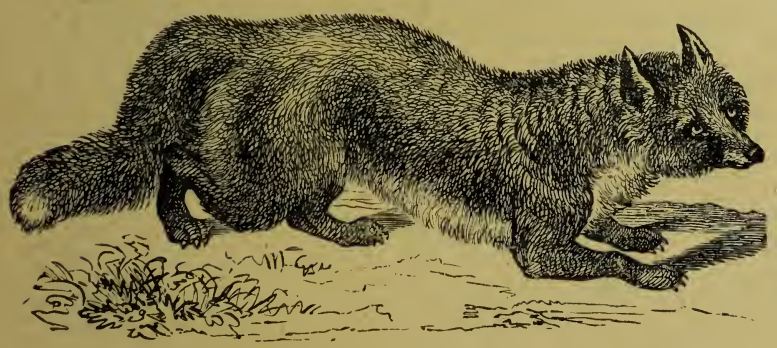

Zorro (aguará).

(zorro grande), el AGUARÁ-POPÉ (zorro con mano extendida), y el AGUARÁ-CHAí el más chico de todos, incansable perseguidores de las aves domésticas; el revoltoso HuRón (marta) y el indomable coAtí que se encuentra en todas partes. 


\section{$-42$}

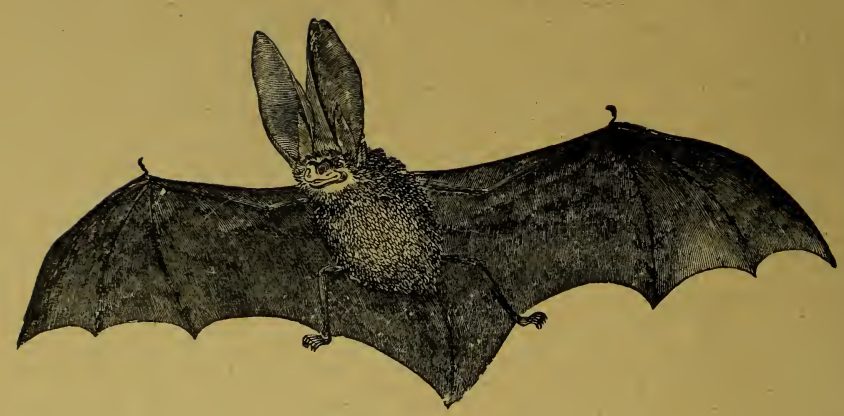

De los qui-
ópteros. El MURCIÉLAGO (mbopí) de dos especies: el grande vaMPIRO, que chupa la sangre de los animales Murciélago (mbopí).

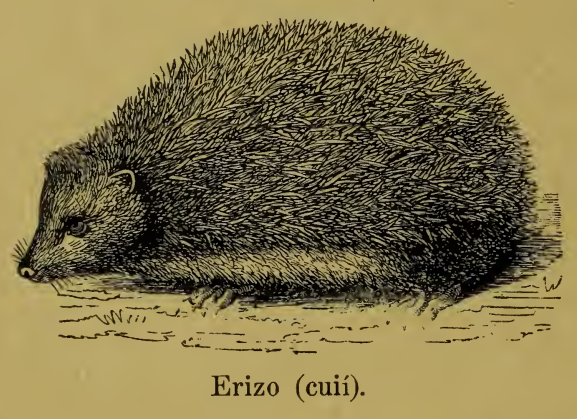

y les deja una herida, y el chico que es inofensivo.

Insectívoros. - El ERIzo (cuií).

Roedores. - El CARPINсHо (capiybá), el más grande de los roedores y abundante en los ríos, arroyos y lagunas; el RATón (anguyá), y el Ratoncito ó LAUCHA

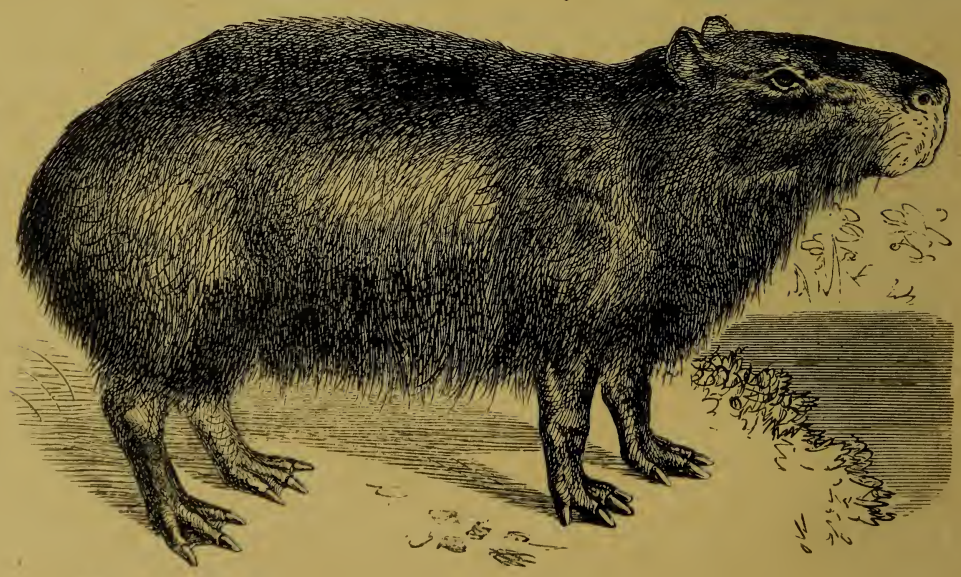

Carpincho (capiybá). 
(anguyá-tutú), el CAvia (acutí) de dos especies: el AcUTí saIYÚ (cavia amarillo) y el ACUTí-PAY (cavia ligero), que salen de noche y hacen mucho mal á las sementeras; el TAPITí y el APEREÁ semejantes al conejo, que son abundantes; y la NuTria (kiyá).

Desdentados. - El hormiguero, del cual existen dos especies: el grande conocido por ÑURUMí y el pequeño con el de CAGUARÉ; y los arMadillos ó tatos, representados por las especies siguien-

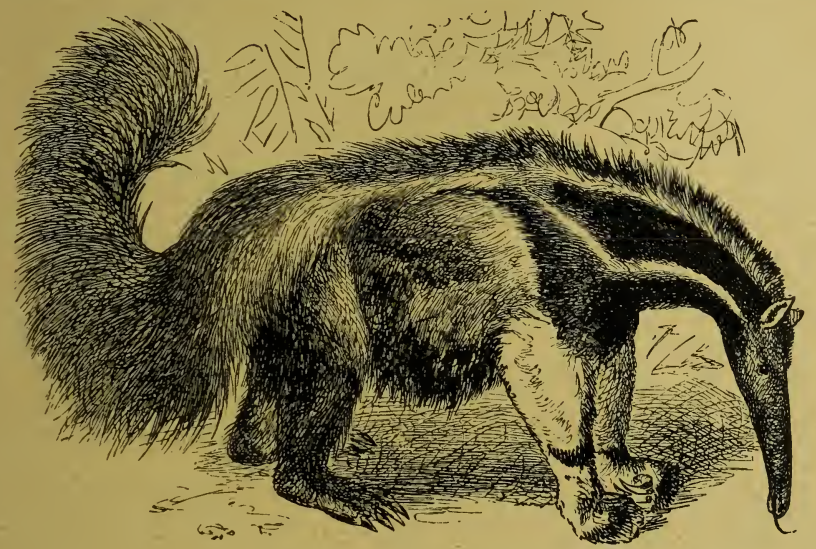

Hormiguero (ñurumí).

tes: el tato gigante (tatú carreta), bastante grande como lo indica su nombre y que sólo existe en los yerbales, el QuirIQUincho (tatú-poyú), el tato NEgro (tatú-jhú), el mátaco (tatú-

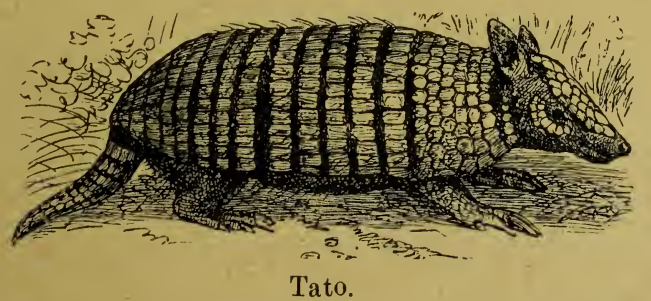

bolita), el TATO LLAGado (tatú-aí) y otros, entre ellos algunos de exquisita carne. 
Perisodáctilos. - El TAPIR, aNTA ó GRAN BESTIA (mboreví) que recorre los ríos y cuyo cuero es muy buscado por ser el más grueso y resistente que se conoce.

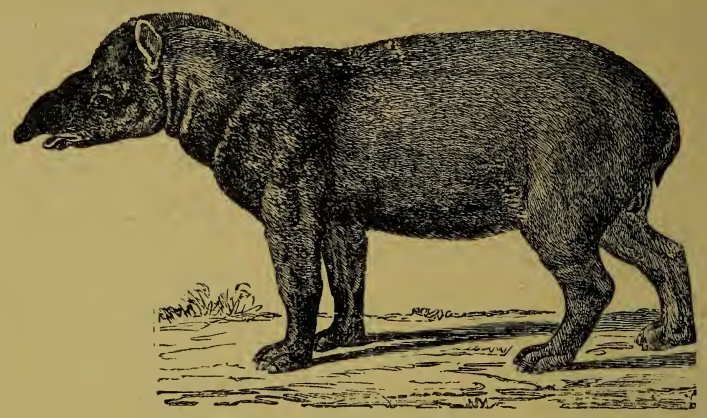

Tapir (mboreví).

Arciodáctilos. - El Jabalí ó PUERCO MONTÉs, que vive en grandes grupos en los bosques y del que existen dos especies: el TAÑYYCATí Y TAY-TETÚ.

Arciodáctilos no rumiantes. - El cIERvo del cual se distinguen cuatro especies: el grande, GUAZÚ-PUcú, el pequeño, GUAZÚ-Í, ó venadillo; el rojo, GUAZÚ-PYTÁ y el GUAZÚ-vIRÁ, corzuela ó cabra del monte, cuyas pieles son muy buscadas.

Marsupiales. - La comadreJa (mycuré), famosa ladrona de gallinas.

\section{Aves.}

Rapaces ó aves de rapiña. - El BUitre, (yribú), impropiamente llamado cuervo, de dos especies: el yrIbú aCABIRAY que se nutren de animales muertos; el REY DE LOS BUITREs (yribú-ruvichá) que es el mayor de todos, poco común: pequeñas íguilas (taguatós), como el caracarí ó carancho, el chimango (caracara-í ó kirikirí), el gavilá́ bRagado (macaguá), el taguató JHObr, 
JHÚ y PItá; el Gavilancillo (taguató-í), el Alconcito, el BUHo, (ñacurutú), el REY DE LOS PAJARITOS (caburé-í), el MOCHUELO (suinda), la LEchuza (1) (urucureá) y el uRutau (guaimingué), de cantar lúgubre.

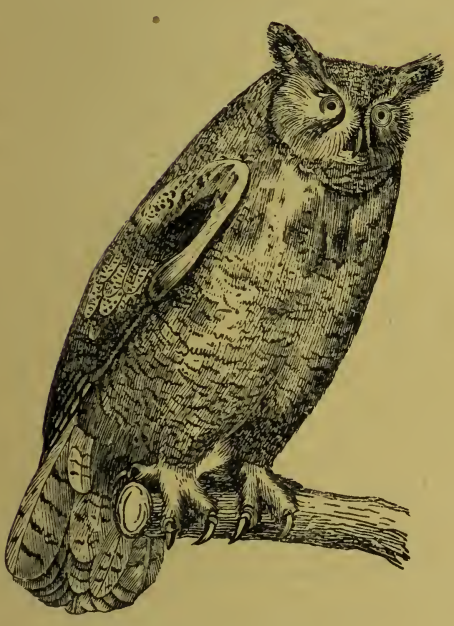

Lechuza (urucureá).

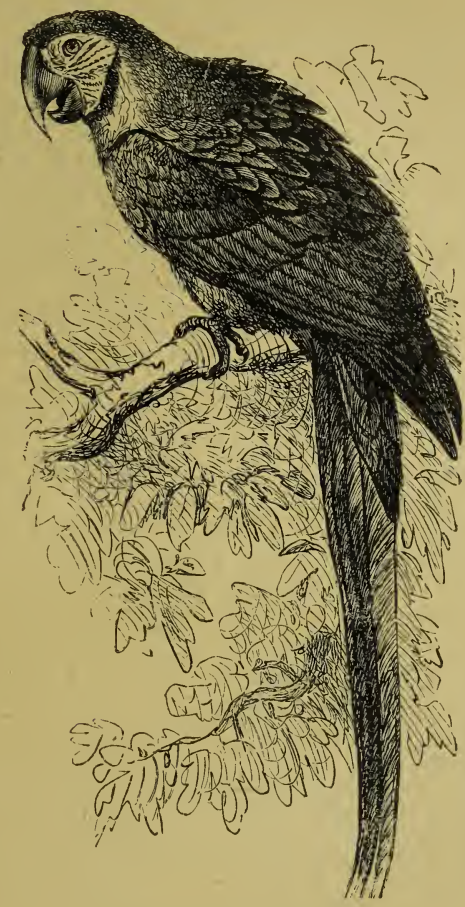

Guacamayo (guaá).

Trepadoras.-El guacamayo ó araucano (guaá), de diferentes especies: el azul, colorado y amarillo y el guacamayo chico (maracaná). De los PAPAGaYos ó loros, un grannúmero, entre

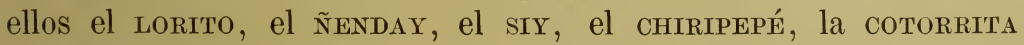
(tuí), que se encuentra con frecuencia en las casas en estado de domesticidad, el tui-chiryry y la preciosa viudita, y final- 
mente el tucán, de hermoso pico, el CaRpintero (ypecú) el aNó y la PIRIRITA.

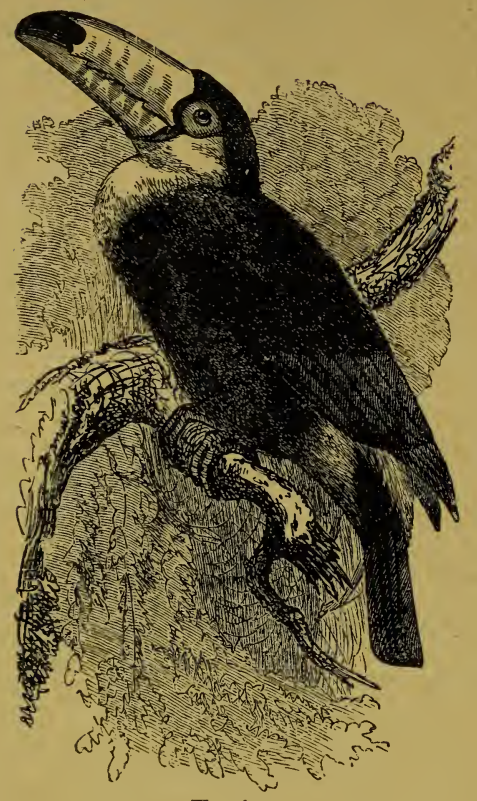

Tucán.

Pájaros.-El cardenal de bello plumaje que abunda en la costa de los ríos; el páJaro CAMPANa (güyrá-campana), muy notable por su canto; la CaLANDRIa, de armonioso cantar. De los zorzales varias especies, entre ellos, el JHABIA PYTÁ y el JHABIA MBOROTÍ; el tORDO ó burlón (güyrá-jhú ó chopí), el TORDO GRANDE (güyrả-jhú-guazú), el TORDO DE BAÑADO (güyrá-jhúchoré) y el Tordito (güyrá-jhú-mí), el BOYERo (surirí), conocido por su nido voluminoso; el HORNERo (Alonso García), llamado así por la forma de su nido de barro; la

GOLONDRINA (mbyyuí), que anuncia la primavera. De la familia de los PICA-FLORES (maynumbys), está representada por varias especies, siendo la más hermosa la que llega hasta las casas. Y, finalmente, el venceJo (tuguay-yetapá), el MARTÍN-PESCADOR, que sólo se alimenta de pescados, el COTINGa (surucuhá), la troglodita (masacaraguai), la URRACA (acahé), el

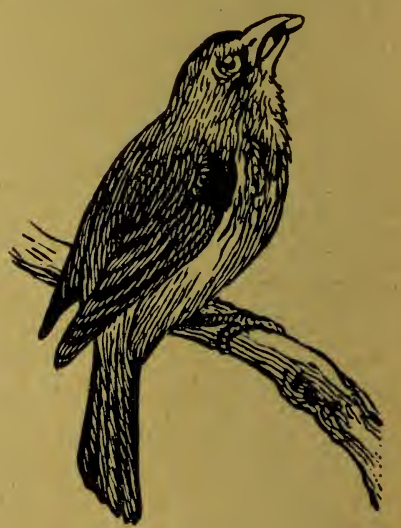

Zorzal. LINDO ó precioso (sayoyby), el PÁJARO DEL FUEGo (güyrá-tatá), el Bienteveo (1) (pitogüe), el Chingolo (chesy-jhasy), el páJaro hechicero (tingazú), la BLANCa Flora, el CHIPIUN, el CHOChí, el 
JLGUERo, el ANUMBY y otros muchos de plumaje vivo y variado, cantores más ó menos diestros, que por no dar extensión á este orden, prescindimos de enumerarlos.

Gallináceas. - El hermoso pavo Montés (mytú); diferentes especies de racús, como el JHÚ, el CARAGUATÁ y el APETí; varias

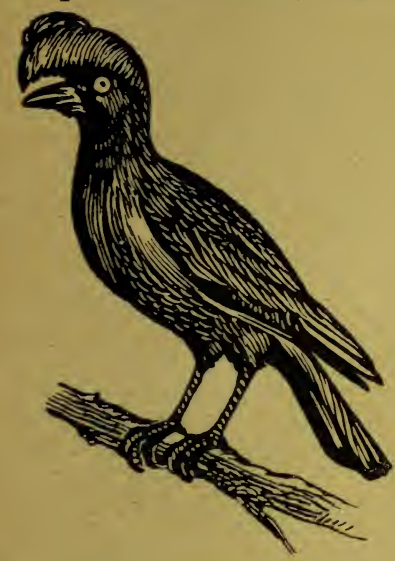

Pavo montés (mytú).

especies de PERDICES como la MARTINETA (ynambúguazú), la PERDIz DEL HOGAR (ynambú-tatá-upá) y la PERDIZ DEL MONTE (mbo-coicocoé).

Las palomas. - Una variedad de las que las principales son: la TORCAz (pycazú-ró), el yerutí y la bonita tóRTola (pycuí-pé).

Zancudas. - La SARía, domesticable, que habita los lugares altos; la CIGÜEÑA (tuyuyú), la GARZA
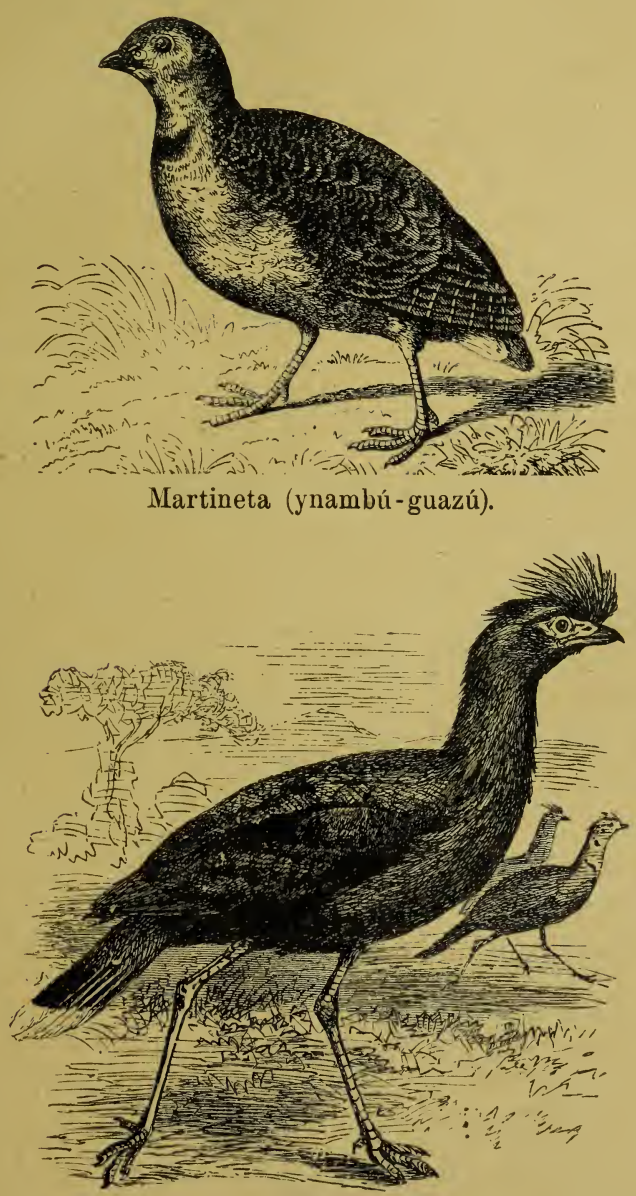

Saría. 
(jhocó), la garza de Penacho (güyrá-tí), cuyas plumas se pagan á buenos precios; el chavarRía (1) (chajhá), verdadero centinela de los bosques; el novelero terutero (teteu), el alcaravan (cuarajhy-mimby), la GruLLA (santelmo), la BECAsINa (yacaberé), el Chorlito (chululú), la avoceta (pahá), el FraILecito (mbatuituí), la chocha pERdiz (yajhaná), la BANDURRIa (curucau), el DOLIENTE ó ibis (carahu), la GALLINETA DE AGUa (ypacaá) y otros.

Corredoras. - La única especie de este orden que existe en el país, es el Avestruz americano (ñandú), cuya pluma es muy estimada.

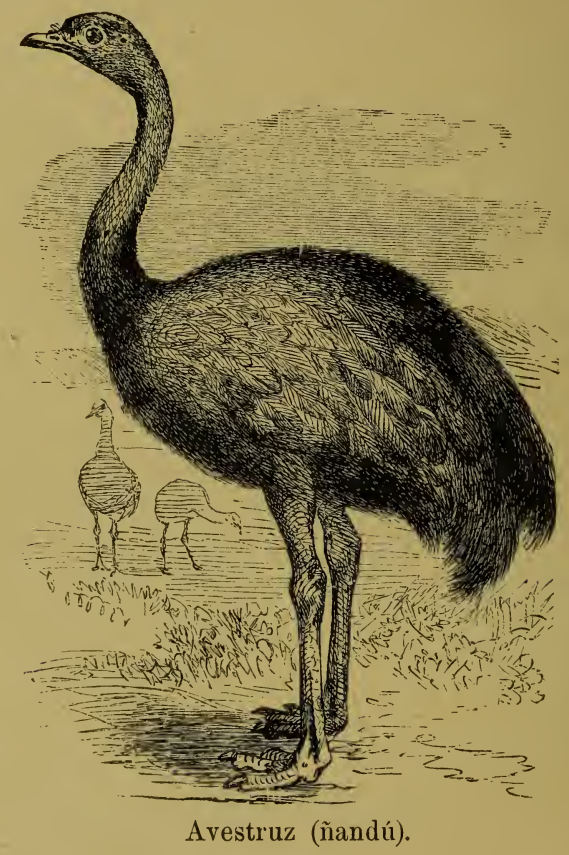

Palmipedas. - Numerosa es la familia de los pa'Tos. Sus especies más conocidas son: el pAto REAL (ypeg-guazú), el PATo cuchara (ypeg-cuchara), el patillo y el suriri, el somormujo (mbiguá) y la gaviota.

(1) Apéndice $1 \times$. 


\section{$-49$}

\section{Réptiles.}

Quelonios. - La TORTuga (carumbé).

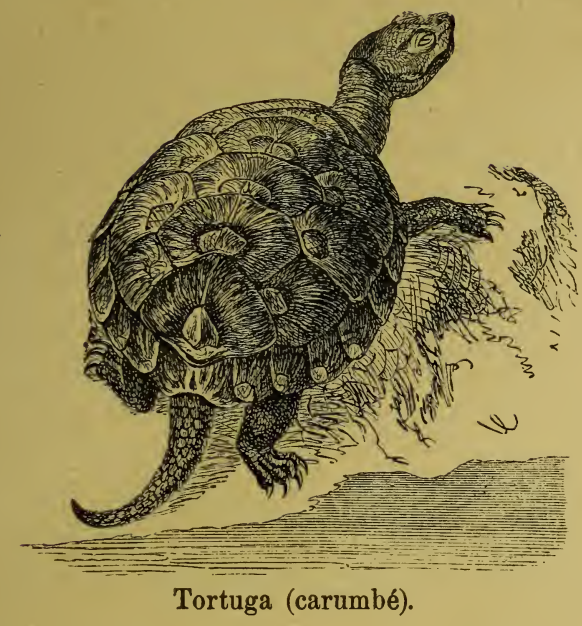

Hidrosaurios.-El CaIMÁN (yacaré), que se encuentra en los ríos, arroyos y hasta en las lagunas; la IgUANa (teyú), la IgUANa GRANDE (teyú-guazú), el camaleón (teyú-tará), la IGUANa VERDE (teyú-jhoby) y la LagartiJa (amberé), que es muy común.

Ofidios. - Entre las culebras, la más notable es la víbora DE CORAL (mboy-chumbé), de diversos colores y brillo; el мвоYЈнову, de color verde, el ÑUAzó, de color oscuro, eternas perseguidoras de los pollitos; y otras que no son venenosas. Las víBORAS más comunes son: la víBoRA DE LA CRUZ (quyryrihó hacácuruzú), así llamada por tener una cruz en la cabeza; la víBora DE CASCABEL (mboy-chiní) que lleva en su cola una espiral escamosa que vibra y resuena cuando está irritada; el ÑANDURIÉ, la más pequeña de las víboras y tan venenosa como las anteriores; el ÑaCANiná, la más grande de las víboras pero no tan venenosa; y finalmente, entre las BOAs, el constrictor (curiyú) que se encuentra hasta de cinco metros de largo. Preténdese que en los yerbales existe el cINocÉFALo (mboy-yaguá) que se anida en los ríos y esteros. 


\section{Anfibios.}

Batracios. - El sapo (cururú), la rana (yuí) y la RANa DEL zARzAL (yuí-pacobá) y otros.

\section{Peces.}

Oseos y cartilaginosos. - Casi todos los ríos y arroyos del Paraguay contienen gran número de pescados de especies varias. Los más importantes son: el surubí, cuyo peso alcanza á 50 kilógramos; el PACÚ que pesa hasta 20 kil.; el DORADo con escamas doradas, como lo indica su nombre, que no bajan de 25 kil.; la Corbina, que apareció en el puerto de Asunción desde el año 1870; el ARMado (ytáguá), la RAYA (yabebuy), el baGRE (mandií), el PAтí, el pIKY, el diminuto роті́ que sólo aparece en el puerto

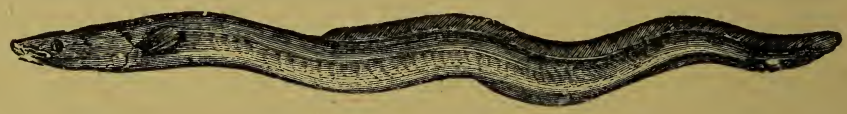

Anguila (mbusú).

de Villeta anualmente; la RAYA (yabebuy), la ANGuila (mbusú) y la especie llamada Lepidosirena con respiración pulmonar. que sólo se encuentra en el Paraguay y el Amazonas.

\section{Invertebrados-Insectos.}

Coleópteros.-El PIRóforo (muhá) y la LUCIÉRNaGa (ysoindy) que esparce una luz intensa; el LAMIa (ybyrá-kytijhá), el GORGoJo (tinguahá) muy perjudicial á los granos; la vaqUita DE SAN ANTONIo (burrito), cuya picadura es característica; el ESCARABajo (enema) y muchos otros.

Ortópteros. - El grillo (ky-yu) muy común; la CUCARACHA (tarabé); мaNTa (mamopa-oimé-nde-coga) y otros.

Hemípteros.-La CIGARRA (ñakyrá), de varias especies; la sanguinaria · CHINCHE COMún importada (1); la CHINCHF DE LOS BOSQULS y otros.

(1) Apendice 19. 
Neurópteros.-El CabaLlito Del DIABLo (ñajhá-tí); la HORMigA LEón (tajyi-leon), perseguidor de insectos; y la HoRMIGa BLANCA ó terme (cupii), que fabrican los tacurús.

Himenópteros.-Las avejas que nos dan la miel, de diferentes
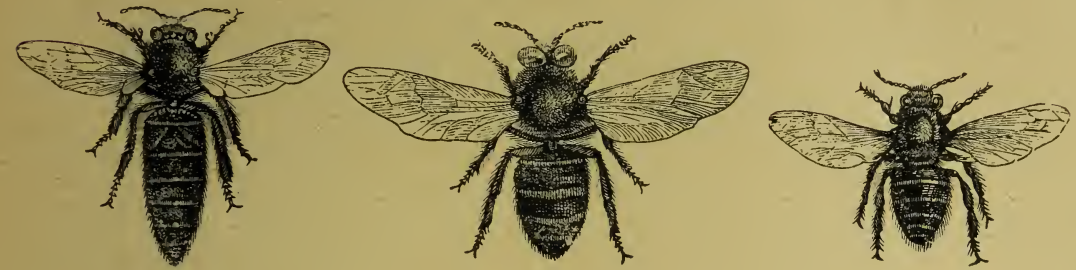

Avejas.

especies, siendo las principales conocidas por APYNGUÁ-REÍ, YATEI, TAPESUHÁ, EIRA-APUA, EIRA-YBYGÜY; el AVISPÓN (mamangá), un gran número de Avispas conocidas por CABYTÁ, CABÚ, CABA-SAIYÚ, CABA-Aguará, la lechiguana, el CAMUatí y otros. Y finalmente, de las horMigas, muchas especies, como el TAJIY-YAGUARETÉ, el TAJiY-guaicurú, que persigue y estermina á las demás hormigas, el TAJIY-RÉ, que aparecen en grandes cantidades cuando está por llover, el TAJIY-PUCú, que es la más ponzoñosa de todas, el AQUEQUE é YSAÚ, eternas destructoras de las plantas delicadas, el ARARAHA, el HACANGó, y otras.

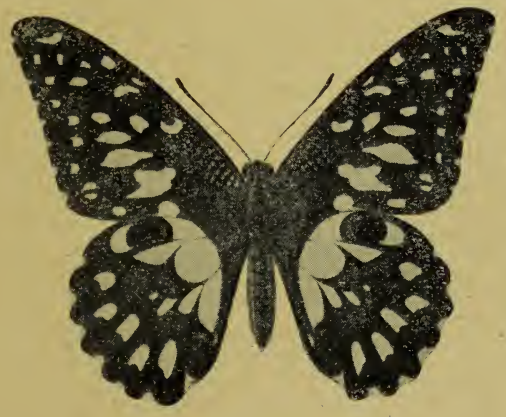

Mariposa.

Lepidópteros. - Una gran variedad de vistosas MARIPosas (panambí), y la polilla, cuyas orugas destruyen las pieles y la ropa.

Dípteros. - Los incómodos MosQuiTos (ñatiús), los TÁBANos (mbutús), azote de las personas y animales, las moscas de diferentes especies, entre ellas la que deposita sus huevos en las materias animales en putrefacción y otros. 
Ápteros. - Las pUlaAs, entre las que se cuentan la pULGA coMun (tunguzú) y la NíGUA (tú), y los RISINos (guirá-ky), que viven en el cuerpo de las aves.

Miriápodos.-El cientopies y el IUlo (ambuhá).

Arácnidos.-Las pacientes é industriosas ARAÑas (ñandús), de diferentes especies, entre ellas la tejedora de ÑANDUTí; la TARÁNTULA (ñandú-cabayú), el ALACRán ó escorpión y los CUIHIS.

Crustáceos.-El cangrejo (yapeuzá).

Anélidos.-La lombriz terrestre (seboí) y la sanguijuela (ysó-pé).

Moluscos. - De la clase del GasteróPodo, el caracol, llamado también hélice (yatytá); y de la del ACÉFALO, la concha (hitá), que los indios se sirvieron de ella para sus adornos.

Animales exóticos. - Entre los animales domésticos importados desde la época de la conquista y que actualmente constituyen la riqueza más considerable del Paraguay se encuentran: mucho ganado vacuno (1) y caballar (2); excelentes especies de ovejas (3), cabras, asnos (4), cerdos, perros, gatos, conejos, aves de corral, hermosos pájaros como el canario y otros muchos.

También el Ixodo llamado garrapata fué introducido durante la dictadura de José Gaspar de Francia, en cuyo comienso causó grandes estragos en el ganado.

Hoy dia va desapareciendo, debido á las medidas profilácticas que se han tomado.
(1) Apéndice 20.
(2) Apéndice 21.
(3) Apéndice 22.
(4) Apéndice 23. 


\section{SEGUNDA PARTE.}

\section{DESCRIPCIÓN DE LA CAPITAL}

$\mathrm{Y}$

\section{DE LOS DISTRITOS DE LA REPÚBLICA.}

I.

\section{La ciudad de la Asunción.}

Situación. - La ciudad de la Asunción está situada á los $25^{\circ} 16^{\prime} 40^{\prime \prime}$ de latitud Sur y $0^{\circ}$ de longitud $\left(59^{\circ} 59^{\prime} 56^{\prime \prime}\right.$ de longitud occidental del meridiano de París), sobre las faldas septentrionales de las colinas de Tacumbú y Lambaré, á 88 metros de altura sobre el nivel del mar y en el recodo formado por la márgen izquierda del río Paraguay, donde los buques entran para efectuar sus operaciones de carga y descarga.

Límites. - El Municipio - de la Capital, comprendidas las parroquias de la Catedral, Encarnación, San Roque, Recoleta, Lambaré y Santísima Trinidad, tiene por límites al Norte, Oeste y Sur, el río Paraguay, al Este, la calle Última ó Embarcación, el arroyo Itay y el camino del Campo Grande que lo separan de los partidos de San Lorenzo de la Frontera, Luque y Limpio respectivamente.

Superficie y población. - El Municipio de la capital se extiende sobre unos 132 kilómetros cuadrados con 70.000 habitantes distribuidos en la forma siguiente:

Catedral y Recoleta . . . . . . . . 22.000

Encarnación y Lambaré. . . . . . . 23.000

San Roque y Santísima Trinidad. . . . 25.000 


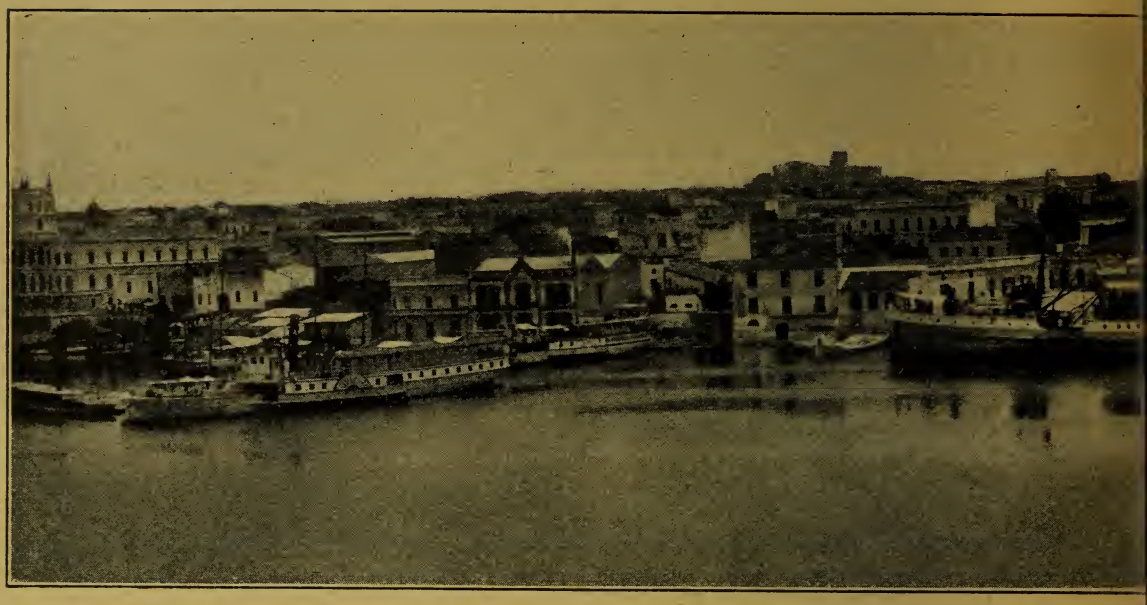

Puerto de

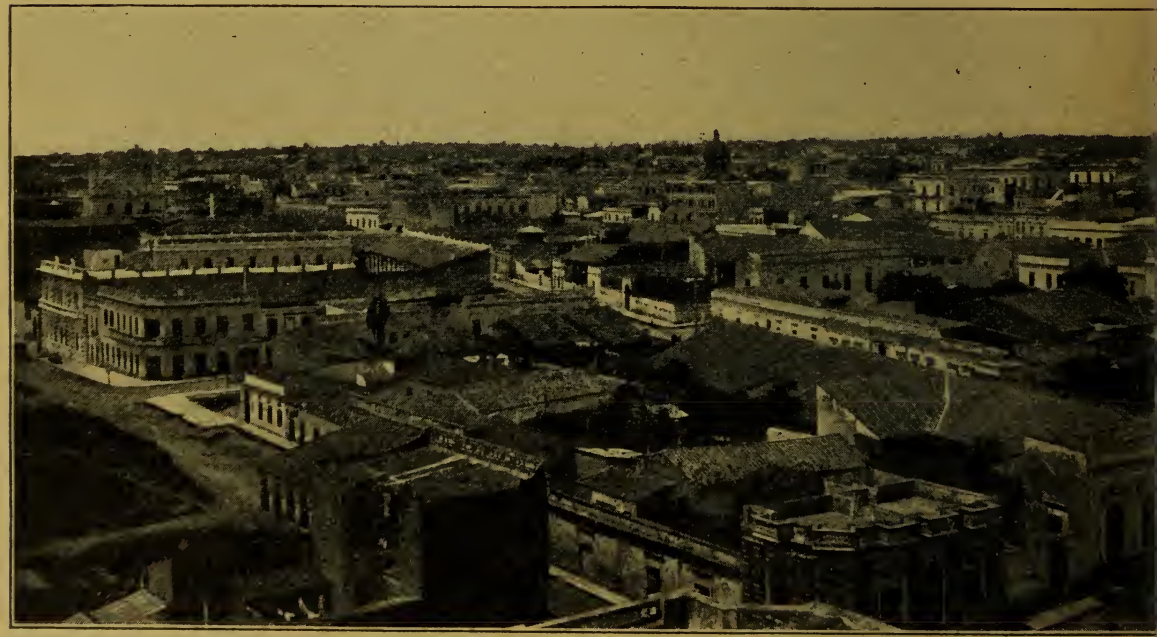

La ciudad 


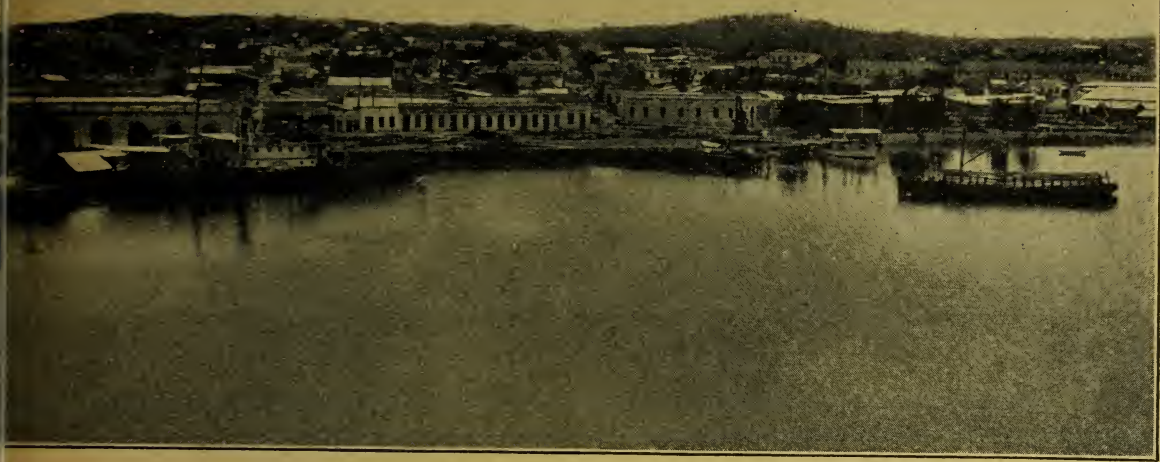

Asunción.

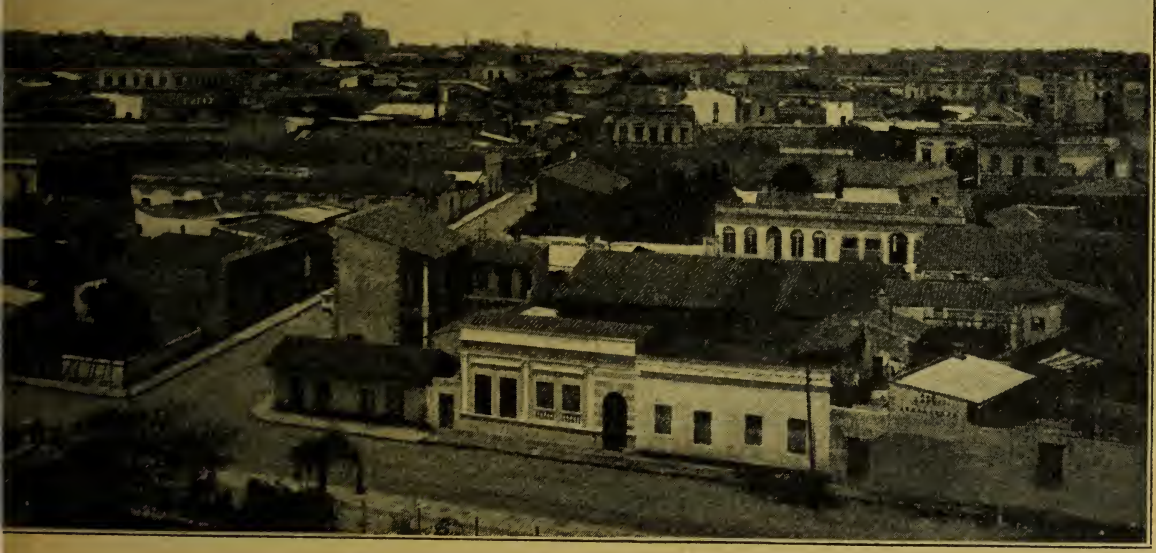

a Asunción. 
Fundación. - La ciudad de la Asunción, antigua Capital de la dominación española en el Río de la Plata, fué fundada el 15 de Agosto de 1536, por Juan de Ayolas, levantando una fortaleza, y en 1538, Domingo Martínez de Irala, echó los cimientos de la ciudad. Los primeros actos de su gobierno fueron: la creación del Cabildo, la repartición de solares á los conquistadores para edificar sus habitaciones y la de cierto número de indios, según el sistema de encomiendas. Este hábil administrador fomentó la construcción de edificios, colocó la piedra fundamental de un templo y circundó la ciudad de un fuerte muro para resguardarla de las frecuentes incursiones de los indígenas.

División de la Capital._-A los fines políticos se divide la capital en tres distritos electorales: Catedral y Recoleta; Encarnación y Lambaré; San Roque y Santísima Trinidad.

A los efectos civiles, escolares y eclesiásticos, judiciales y municipales, la ciudad se divide en las seis parroquias expresadas.

La Catedral está limitada por las calles 14 de Mayo, Igatimí, Amambay y Paraguarí y río Paraguay. Los principales edificios con que cuenta, son: los templos de la Catedral bendecida solémnemente el 27 de Octubre de 1845, y Encarnación (en cons-

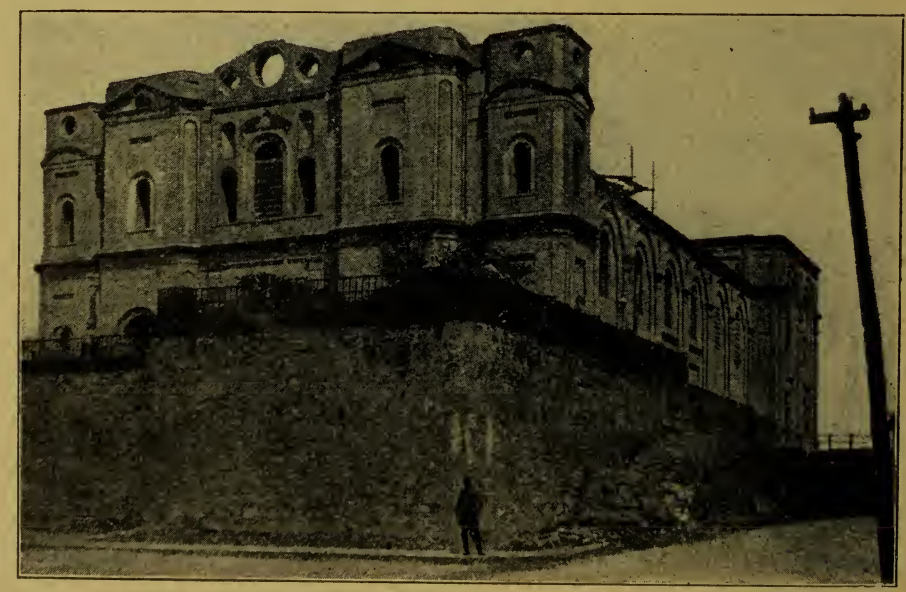

Iglesia de la Encarnación (en construcción). 
trucción), el Cabildo, el Palacio Episcopal (en construcción); la Estación del ferro-carril, el Teatro Nacional, la Cárcel Pública, el Departamento General de Policía, la Dirección General de Correos y Telégrafos, la Universidad y Colegio Nacional, la casa de Justicia, el Seminario Conciliar, el Mercado Central, el Colegio de la Providencia, el Banco Agrícola del Paraguay, el Oratorio y el Teatro en construcción, etc.

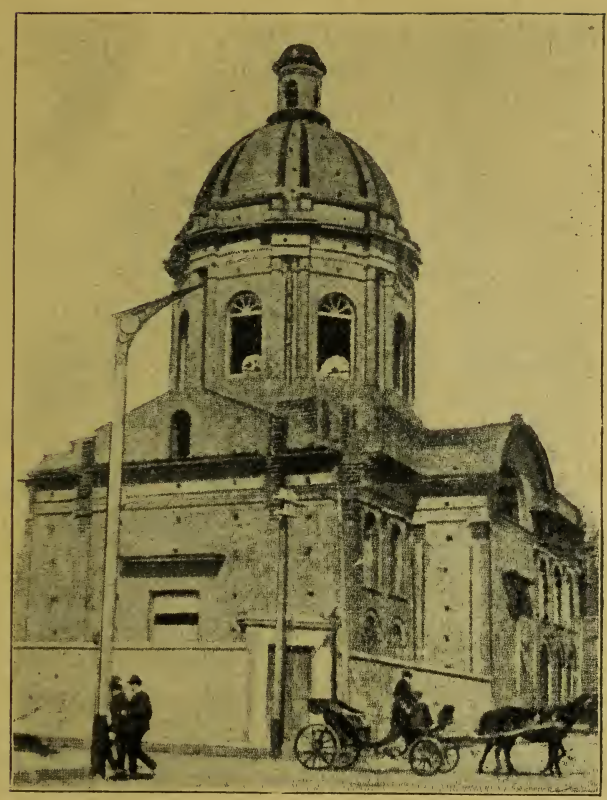

Oratorio de la Virgen de la Asunción.

La Excarnación, limitada por el río Paraguay, Arroyo Ferreira, camino á Lambaré y calles Amambay, Igatimí y 14 de Mayo, contiene los siguientes edificios: El Palacio Nacional, los cuarteles de caballería é infantería, la Aduana Central, los hospitales de Caridad y Militar, la Estación del tramway, el Molino Nacional, $y$ el Banco Paraguayo.

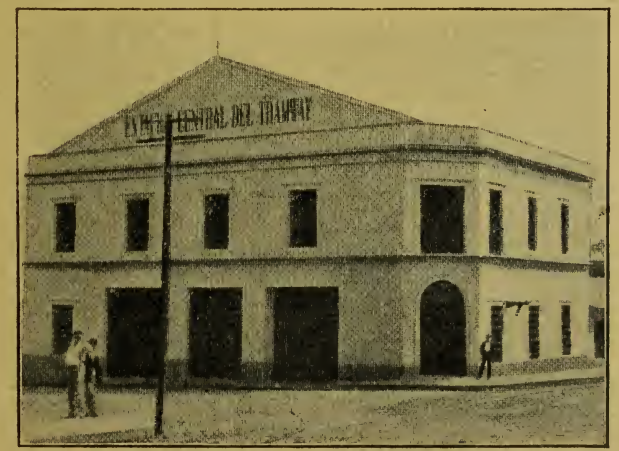

Estación central del Tramway. 
San Roque, limitada por las calles Paraguarí, camino á Lambaré, Arroyo Ferreira, calle San Leandro, camino á San Antonio, calles del Cementerio, España y Olimpo y el río Paraguay, en-

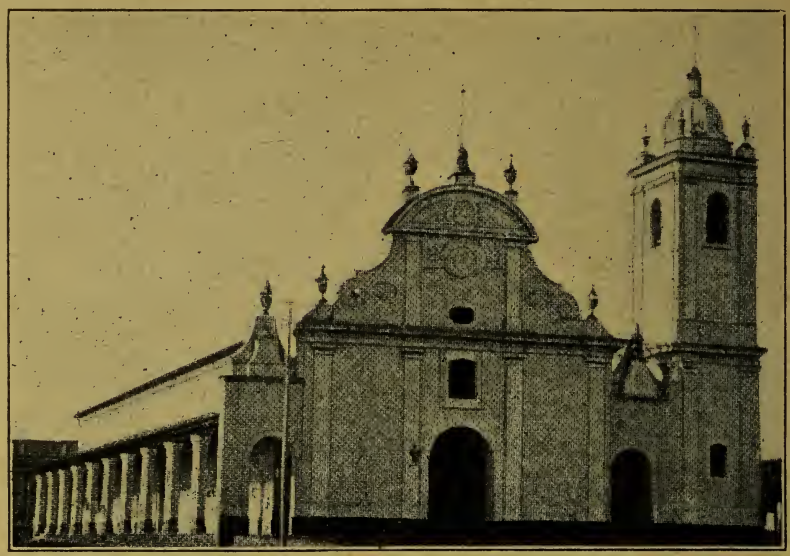

Iglesia de San Roque.

cierra el templo de su nombre construido en el año de 1851 y el Mercado Guerreros.

Recoleta, limitada por la calle del Cementerio, camino á

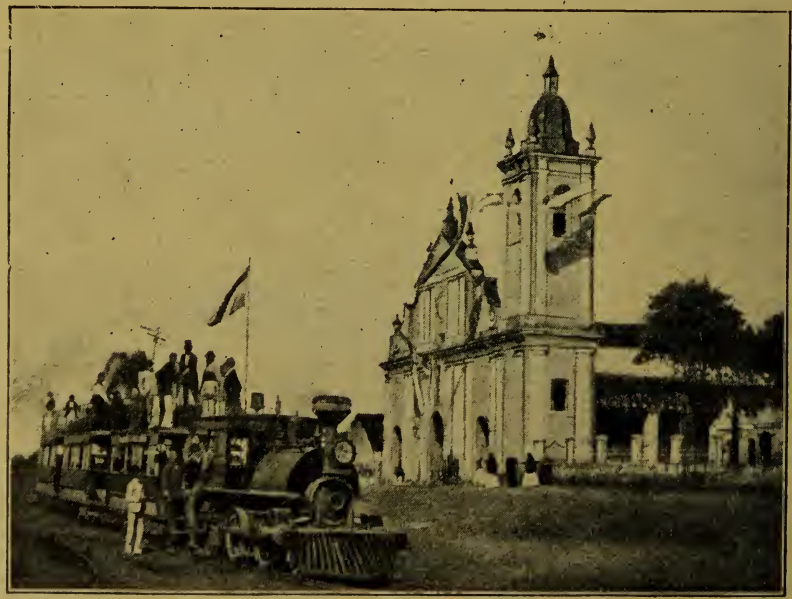

Iglesia de la Recoleta. 
San Antonio, calle Última ó Embarcación, arroyo Itay, camino á Luque y calle Manorá, con los siguientes edificios: el templo y cementerio de su nombre, Villa Morra y un gran número de hermosas quintas.

Lambaré, limitada por el río Paraguay, calle Última ó Embarcación, camino á San Antonio, calle San Leandro y arroyo Ferreira. En el centro de la población se levanta el templo construido en el año de 1845.

Santísima Trinidad, limitada por las calles Olimpo, España, y Manorá, camino á Luque, arroyo Itay, camino del Campo Grande y río Paraguay, encierra el templo de su nombre mandado construir bajo el gobierno de Carlos A. López, y la Escuela de Agricultura.

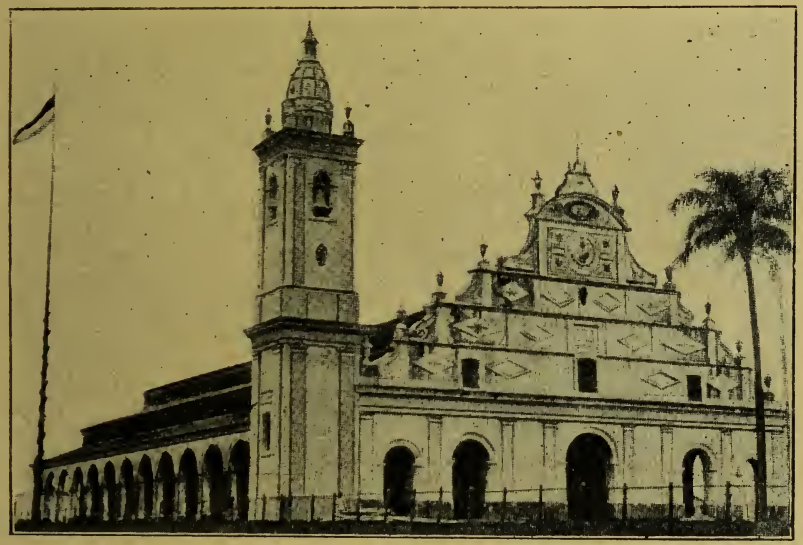

Iglesia de la Santísima Trinidad.

La ciudad de la Asunción es el asiento y residencia de las autoridades de la Nación, del Obispado y del Cuerpo Diplomático y Consular.

Calles. - Las calles de la Asunción, aunque angostas, están bien delineadas y trazadas de Norte á Sur y de Este á Oeste. Ellas 
alcanzan á unas 100 , cortadas en su mayor parte bajo un ángulo recto, que interceptan 500 manzanas de 86 á 100 metros de longitud cada una, de las cuales más de la mitad están edificadas. .

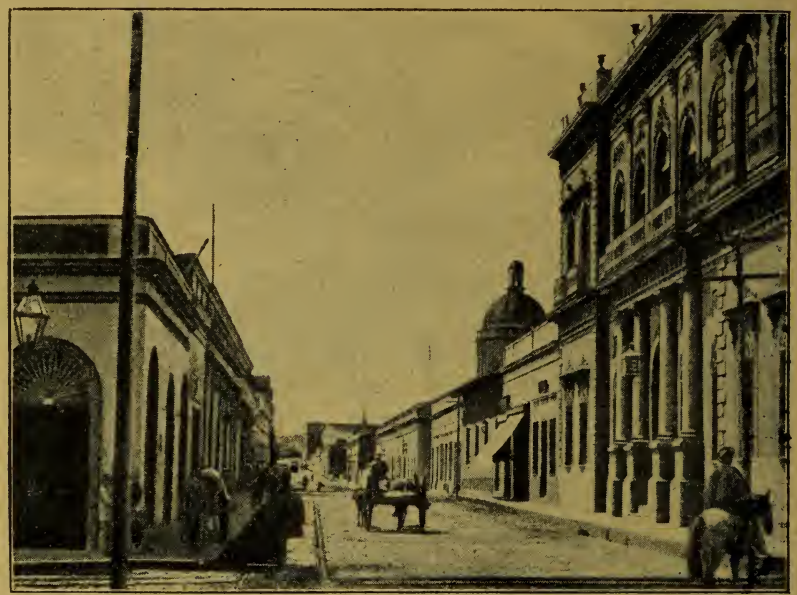

Calle de la Palma.

La anchura general de las calles es de 14 metros, inclusa las veredas de 2 metros.

La calle Independencia Nacional, de Norte á Sur, sirve de base para dividir la nomenclatura de las calles largueras.

Afirmado.-El empedrado se extiende en una tercera parte de la ciudad edificada y se compone de piedras de diferentes formas y tamaños, extraidas de las canteras de Tacumbú.

Edificios. - La parte material de la Asunción ha mejorado notablemente desde el año 1890. Las necesidades y el buen gusto han hecho desaparecer los edificios dejados por la dominación española.

Monumentos. - Los más importantes son: el Patacio Nacional, considerado como uno de los mejores de Sud América, sobre la 


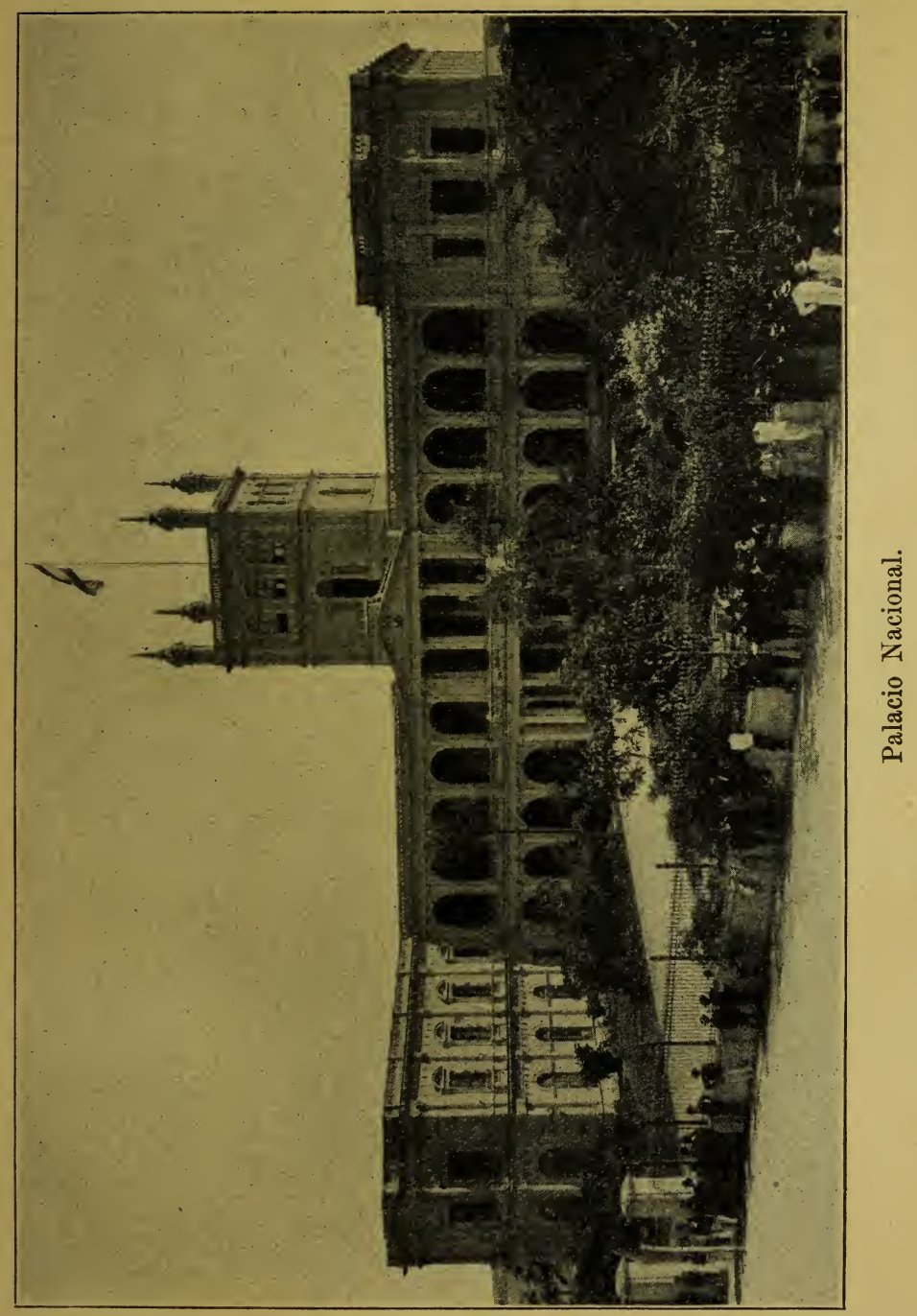


barranquera del río Paraguay, mandado construir por el gobierno de Francisco S. López; el Cabildo, en la Plaza de Armas, tam-

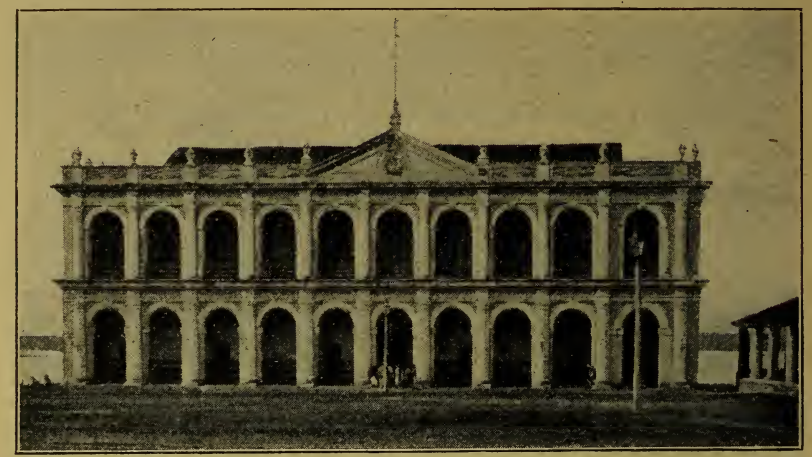

Ell Cabildo.

bién sobre la barranquera del mismo río; el Oratorio DE LA VIRgen De LA Asunción en la esquina de la Palma y 25 de Diciembre; la estatua de "La Libertad» en la Plaza Constitución; el teatro

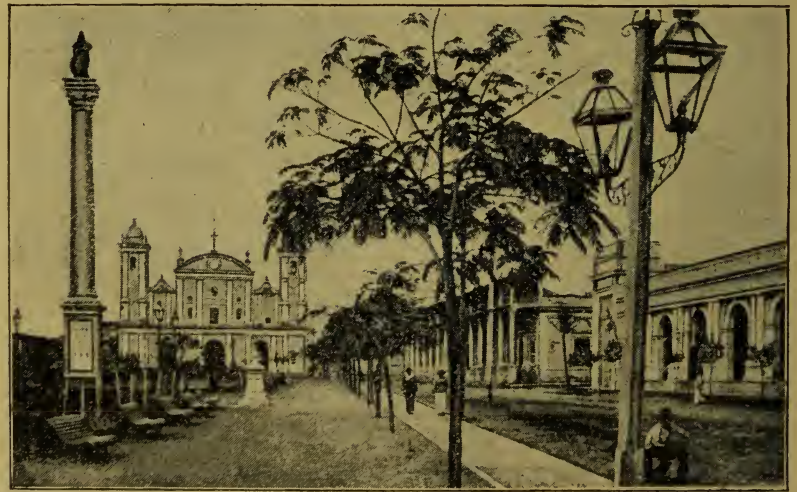

Plaza Constitución. - Estatua de la Libertad. - Catedral.

en construcción que ocupa la manzana formada por las calles 
Libertad, Iturbe, Asunción y Yegros; la Estación DeL FERRo-

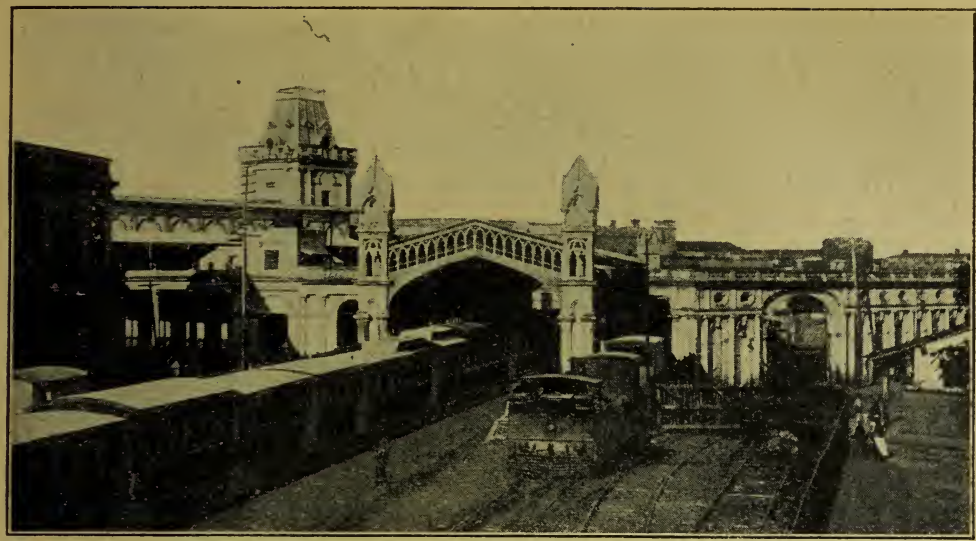

Estación del Ferro Carril.

CARRIL, en la manzana formada por las calles Libertad, Paraguarí, Asunción y Escalada; el Departamento General de Policía, en

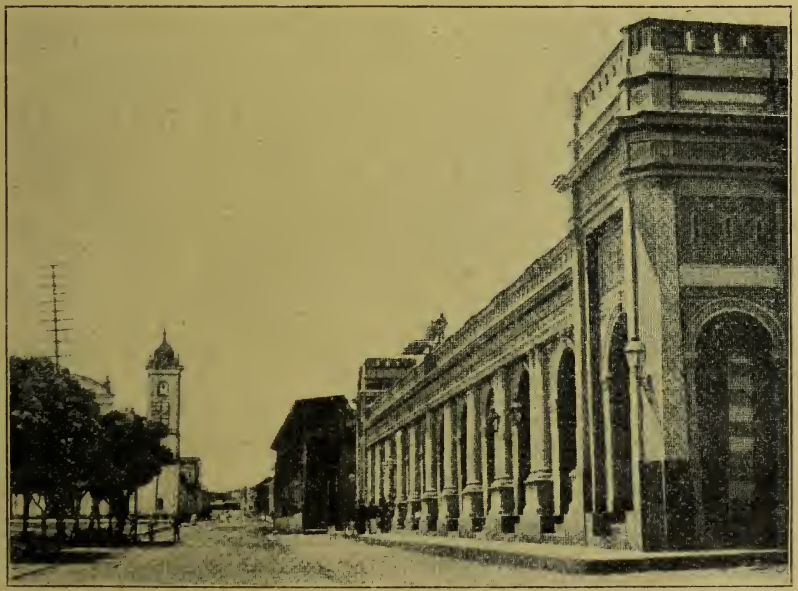

Departamento General de Policía.

toda la manzana formada por las calles Buenos Aires, 25 de Diciembre, Villa Rica y 25 de Noviembre. 
Plazas. - La Asunción cuenta con tres plazas de recreo: la URUGUAÝ, compuesta de cuatro manzanas, formada por las calles Libertad, Escalada, Igualdad y Antequera; INDEPENDENCIA, de una manzana, entre la calle Estrella, 25 de Diciembre, Oliva y 25 de Noviembre; y Constituciós, en otra manzana, comprendida entre las calles Buenos Aires, 25 de Noviembre, Comuneros y 25 de Diciembre. Las tres plazas están adornadas con hermosas arboledas.

Tramways. - Tres empresas de tramways, tienen establecidas sus líneas que recorren la ciudad en distintas direcciones, uniéndola con la Ciudad Nueva, á 1.500 metros; Colina de Tacumbú, á 1.900 metros; Tablada de la Santísima Trinidad, á 6.500 metros y San Lorenzo del Campo Grande á 14 kilómetros; siendo de mayor importancia estas dos últimas tanto por su extensión como por que los lugares recorridos son más poblados.

Hospitales.-Los hospitales que existen dentro del municipio de la capital son: el Hospital DE CARIDAD, atendido por Hermanas de esta órden y un médico, bajo la inmediata dirección de la "Sociedad de Beneficencia del Paraguay" que la componen las primeras matronas de la sociedad asuncena, y el Hospital Mritiar, atendido por un cirujano mayor, cuatro ayudantes y un boticario, bajo la dependencia del Ministerio de Guerra y Marina.

Asilos. - Un asilo de mendigos en la parroquia de la Trinidad, á 4 kilómetros de la capital, fundado y atendido por damas asuncenas, se encarga del cuidado de los pobres menesterosos.

Cementerios.--Existen el de la Recoleta, al lado Oeste de la iglesia de su nombre, erigido por decreto de los cónsules Carlos A. López y Mariano R. Alonzo en fecha 30 de Mayo de 1842 ; el del Mangrullo, al Oeste de la capital, en la parroquia de la Encarnación, construido en 1870 por las fuerzas brasileñas; el Españot, en la calle Igatimí, construido en 1875 por la Sociedad Española de Socorros Mutuos para los miembros de la misma; y el de Protestantes, inmediato al de la Recoleta. 
Alumbrado. - Las principales calles de la ciudad están iluminadas con luz eléctrica y á carburo.

Limpieza.-El servicio de limpieza general, se hace por medio de carros, que recorren diariamente toda la ciudad.

Aguas potables. - La población de la capital se provee de agua del pozo Artesiano de la calle Estrella, y de varios manantiales que se encuentran en sus alrededores, tales como el Icuá-Hospital, Icuá-Rejala, Icuá-Pacobá, que gozan de gran aceptación. Muchas familias se proveen también de algibes.

Orden público.-Está garantido por el servicio general de policía, compuesto de 3 Comisarías seccionales y 6 sub-comisarías, distribuidas en la ciudad y sus alrededores.

Cárcel. - Recientemente construida en la esquina de las calles Yegros y Comuneros está destinada á la reclusión de los delincuentes.

Teatro. - El Teatro Nacional, en la calle Villa Rica, abierto en el año 1889, es donde generalmente funcionan las compañías españolas.

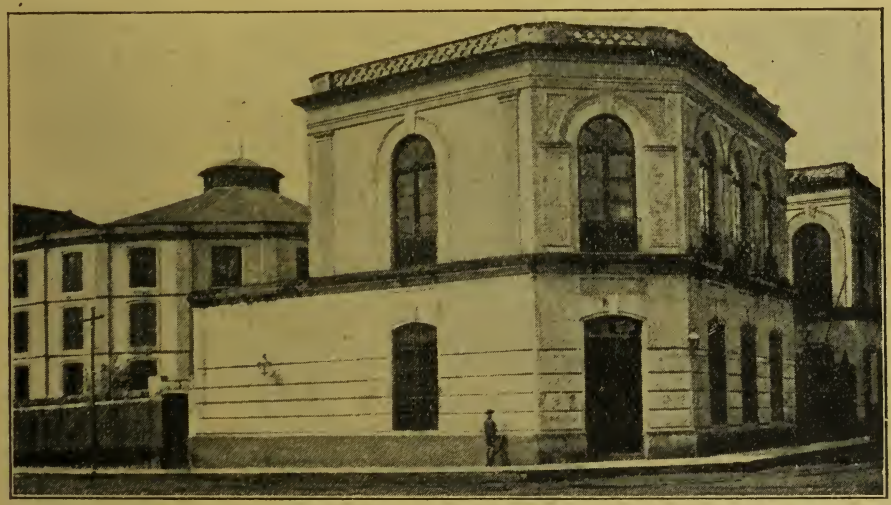

Teatro Nacional.

Sociedades. - Existen varias que persiguen propósitos de interés general, y entre ellas, la Sociedad de Beneficencia del 
Paraguay, de Beneficencia y Caridad, la de San Vicente de Paul y varias de Socorros Mutuos de diversas nacionalidades, habiendo algunas que tienen locales propios.

Clubs. - Hay varios formados con fines meramente recreativos.

Periódicos. - Existen en la ciudad diez, entre los cuales, seis aparecen diariamente.

Mercados. - Abastecen á la población tres mercados: el CENTRAL, que es el más concurrido y ocupa la manzana formada por las calles de la Palma, Independencia Nacional, Estrella y 25 de Noviembre; el Deu Puerto, en el local llamado "Arsenal-cué», en la calle Estero Bellaco; y el De Guerrero, en la esquina de Presidente Carnot y Brasil.

Matadero.-Existe en la parroquia de la Santísima Trinidad á 6.500 metros al Este de la capital.

Bancos. - La Asunción cuenta con seis Bancos: Mercantil del Paraguay, Paraguayo, Agrícola del Paraguay, Caja de Crédito Comercial, Territorial del Paraguay y Popular del Paraguay.

Teléfono. - Una empresa telefónica extiende sus redes por la ciudad y sus alrededores.

Correos. - El servicio postal se hace por una oficina central, dos sucursales y buzones repartidos en varios puntos de la capital.

Industrias. - Las principales son: molinos á vapor, fundiciones, talleres mecánicos, destilerías, fábrica de cerveza, de galletitas, de aceites, de jabón, hielo, de fósforos, de esencias, de baldosas, de ladrillos, aserraderos á vapor, astilleros etc.

II.

\section{Primer distrito.}

Situación, IMPORTANCIA, INDUSTRIA, ASPECTO, pOBlación.

El Primer Distrito es uno de los más importantes del Norte de la República, por que abraza los más ricos yerbales y preciados campos. 
Los caudalosos ríos que lo limitan y surcan con sus inumerables afluentes, las lluvias abundantes que lo riegan y un sol tropical esparciendo calor y vida, convierten esta región en una de las más fértiles y privilegiada del país. Desde el Aquidaban al Norte, presenta deliciosos valles formados por los ramales de las sierras de Amambay, que se ramifican en dirección al Oeste $y$ al Sur del Aquidaban, los terrenos son anegadizos, entrecortados de arroyos, bosques y campos. Tiene ricas producciones é industria, siendo las más importantes: ganado vacuno que no baja de 350.000 cabezas, yerba-mate, cuya elaboración asciende anualmente á 5.000.000 de kilógramos, dos importantes saladeros, preciosas maderas, excelentes pastos y agricultura en reducida escala. La población es de 34.580 habitantes.

División política; partidos; Capital. - Está dividido el distrito en 6 PARTIDOS.

Villa Concepción. - Capital del distrito y partido de su nombre, sobre la márgen izquierda del río Paraguay, fundada en 1773 por el Gobernador Agustin Fernando de Pinedo. Es la ciudad más importante de la República, despues de la Asunción. Es la $3^{a}$ aduana de la República. Tiene un Colegio Nacional, edificios importantes, entre los que descuellan el cuartel, la aduana, el templo, el mercado y muchas casas de construcción moderna para comercio y familias. Existen además, Bancos particulares y una agencia del Banco Agrícola y otra del Banco Mercantil, oficina de correos, tramway, telégrafo, teléfono, hoteles, clubs, etc., y varias casas de comercio, de las cuales la mayor parte se proveen directamente de los mercados del Plata. La población de todo el partido es de 12.600 habitantes y su industria principal es la ganadería, la saladería y la fabricación de cal.

Villa Concepción cuenta además con SAN CARLOS, sobre el río Apa, Paso Barreto sobre el río Aquidaban, que son poblaciones de gran porvenir, así como las colonias Risso y Puerto Max sobre el río Paraguay.

Horqueta. - Con 5.630 habitantes, al Noreste de Villa Concepción; es rico el partido en ganadería y agricultura. 
Belen.-Sobre el río Ipané, último pueblo fundado por los Jesuitas, con 4.350 habitantes; progresa considerablemente.

Bella Vista, Pedro Juan Caballero y Loreto. - Recientemente fundados con $3.700,2.900$ y 2.400 habitantes respectivamente, son pueblos de gran porvenir, particularmente los dos primeros que son fronterizos con el Brasil.

III.

\section{Segundo distrito.}

SitUACIÓN, IMPORTANCIA, ASPECTO, POBLACIÓN, INDUSTRIA.

Este distrito es el más importante de los del Norte, por su población y extensión territorial. Surcado de importantes ríos y arroyos, navegables la mayor parte, sirven para el transporte de la yerba-mate y otras producciones; cubierto de bosques yerbales y con una espléndida vegetación tropical. La población es de 37.429 habitantes y su industria se distingue especialmente en la cría de ganado vacuno que no baja de 400.000 cabezas, en la elaboración de la yerba-mate, en la fabricación de aguardiente, miel etc., y en la agricultura en general.

División política; partidos; Capital.-El Segundo Distrito comprende 9 PARTIDOS.

La capital del distrito y del partido, es la ciudad de la Villa de San Pedro, situada á inmediaciones del río Jejuí y á 12 kilómetros del Puerto Curuzú Chicá sobre el río Paraguay. Fué fundada en 1784 por José Ferreira y Pedro Gracía durante la gobernación de Pedro Melo de Portugal. Es la 8a aduana de la República; cuenta con una agencia del Banco Agrícola, telégrafo, correos y casas de comercio con fuertes capitales. La población de todo el partido es de 8.926 habitantes y su industria consiste en la ganadería, la elaboración de la yerba-mate y la agricultura.

Villa de San Pedro, cuenta además con la colonia Nueva Germania sobre el río Jejuí, poblada con alemanes, y la poblacion de Turin.

San Estanisla0.-Fundado por los Jesuitas en 1749 , se encuentra situado sobre una pequeña prominencia á inmediaciones del 
arroyo Tapiracuay. Cuenta con un lindo templo, agencia del Banco Agrícola, oficina de correos y muchas casas de comercio. Tiene todo el partido 12.521 habitantes, dedicándose ellos con especialidad á la elaboración de la yerba-mate, la agricultura y ganadería.

Villa del Rosario.-Situada sobre la márgen izquierda del río Cuarepotí, á 4 kilómetros del río Paraguay que le sirve de puerto. Fué fundada en 1783 por el Gobernador Pedro Melo de Portugal. Tiene agencia del Banco Agrícola, telégrafo, varias casas de comercio y 3.640 habitantes, en todo el partido. Sus campos son excelentes para la cría de ganado vacuno.

Villa del Rosario, tiene la importante colonia Trinacria fundada con colonos sicilianos.

Itacurubi del Rosario. - Distante de la Villa del Rosario 34 kilómetros al Este y todo el partido con 2.625 habitantes. Sus campos y tierras son aptas par la ganadería y la agricultura.

Lima.-Con 1.210 habitantes en todo el partido, está situado sobre la márgen izquierda del arroyo Aguaray. La ganadería y la agricultura constituyen su industria.

Unión. - A 12 kilómetros Sur de San Estanislao; tiene todo el partido 2.180 habitantes. La ganadería y la agricultura constituyen su industria.

Tacuaty. - Situado sobre la márgen izquierda del rio Ipané, con 1.450 habitantes en todo el partido. Su industria es la elaboración de la yerba-mate. Tiene hermosos bosques con una variedad de maderas.

Villa Igatimi y Villa Curuguaty. - Son dos partidos recien fundados, en las fronteras con el Brasil. El primero tiene 2.443 habitantes y el segundo 2.430. La yerba-mate es la principal industria de ambos.

\section{IV.}

\section{Tercer distrito.}

SitUACión, ASPECTO, POBLACión, indUUStRias.

El Tercer Distrito se encuentra situado al Norte de la Asunción. Atravesado en su parte central por la cordillera de Altos 
cuyo pié está regado en el Norte por el río Piribebuy, en el Sur por la laguna Ipacaraí y río Salado y por el Oeste por el río Paraguay; ofrece esta región magníficos campos, ricas selvas con abundantes maderas de todas clases y tierras propias para todos los cultivos y particularmente para el café que produce en abundancia. La población asciende á 36.195 habitantes. La ganadería, la agricultura, la extracción de la piedra-loza y la fabricación de sombreros, constituyen las industrias principales.

División política; partidos; Capital. — Se divide el distrito en 6 PARTIDOS.

Altos. - Sobre la cumbre de la cordillera de su nombre, es la capital del distrito, con 8.715 habitantes en todo el partido. Tiene el mérito de su antigüedad, por haber sido uno de los primeros que fundó el Gobernador Domingo Martínez de Irala, en 1538. Altos, cuenta con edificios de construcción moderna, telégrafo, etc., y las industrias del partido consisten en la ganadería, agricultura, explotación de almendras de coco, alfarería, fabricación de miel, etc.

Arroyos y Esteros. - Con 6.120 inclusive los habitantes de todo el partido, está situado al Norte de Altos. La ganadería, la extracción de fibras de plantas textiles y la explotación de maderas y la agricultura, constituye su industria.

Caacupé. - Sobre la cumbre de la cordillera de los Altos, muy conocido por existir allí el santuario de la Vírgen de la Concepción de los Milagros, cuya peregrinación anual se efectúa el 8 de Diciembre. Caacupé ha progresado notablemente. Cuenta con centros sociales, tranvías, diligencias, telégrafo, teléfono, edificios de construcción moderna, un gran comercio, industrias importantes y una población que no baja de 6.080 habitantes.

Tobati._También sobre la cordillera de los Altos tiene la importancia de su antigüedad. Fué fundado en 1538 por Domingo Nartínez de Irala. Cuenta con telégrafo, algunas industrias; posee el kaolín y tiene 5.054 habitantes en todo el partido. 
Emboscada. - Con 4.640 habitantes, situado sobre la misma cordillera de los Altos á 9 kilómetros del Puerto Arecutacuá sobre el río Paraguay, con estación telegráfica. Las mejores piedras de construcción se extraen de sus canteras y en sus exhuberantes campos pastan ganados de todas clases, para cuya mejora se han introducido padrillos pura sangre de carrera y toros Durhain y Holstein. Los grandes cafetales que existen en el partido y la explotación de almendra de coco, le auguran un brillante porvenir.

La penitenciaria destinada para la reclusión de los presos, se encuentra en este partido.

Atyrá. - Situado como los anteriores, sobre la cordillera de los Altos, con 4.274 habitantes en todo el partido. Sus principales industrias son la agricultura en general, la fabricación de recados, sillas de cuero y jergas de lana. Tiene telégrafo.

San Bernardino. - Sobre la laguna Ipacaraí con 1.312 habitantes, fundado en la colonia de su nombre por alemanes. Su pintoresca situación y hermosos paisajes, lo hạn convertido en un delicioso lugar de recreo. Todos los años inumerables familias

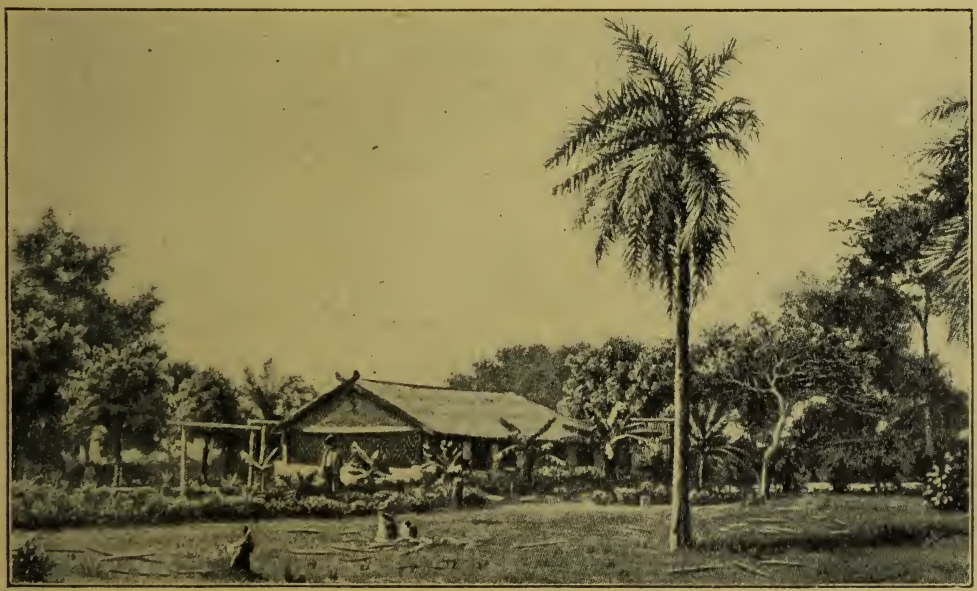

San Bernardino (Colonía alemana). 


\section{$-72-$}

extranjeras y nacionales, atraídas por su benigno clima y saludables baños, afluyen á aquel pueblo que día á día aumenta el bienestar de la vida con sus hermosos chalets, espléndidos hoteles y fáciles comunicaciones con la Asunción.

\section{V.}

\section{Cuarto distrito.}

SITUACIÓN, ASPECTO, POBLACIÓN, INDUSTRIA, RIQUEZA.

Situado este distrito al Norte de las últimas ramificaciones de la cordillera de los Altos, ofrece en general un terreno llano, cubierto de bosques vírgenes con maderas de todas clases, de hermosos pastos, propios para alimentar inmensos rebaños de ganados. Tiene 30.262 habitantes y su industria consiste en la ganadería que es su principal riqueza y en la agricultura en general.

División política; Partidos; Capital._-El distrito comprende 3 PARTIDOS.

Barrero Grande.-Sobre el río Piribebuy, con 9.143 habitantes, es la capital del distrito y del partido de su nombre. Tiene telégrafo y producciones importantes como el tabaco, para cuya preparación el Banco Agrícola ha establecido un secadero sistema cubano, pero su principal industria es la ganadería y la explotación de maderas.

Fué fundado en 1770 por el Gobernador Carlos Morfi, con el nombre de San Roque, que más tarde se cambió por el actual.

Caraguatay.-Situado á inmediaciones del arroyo Ihagüy, al Norte del anterior con 11.000 habitantes. Sus principales industrias consisten en la ganadería, la explotación de las ricas y variadas maderas y la agricultura en general. Posee un ingenio de azúcar que no basta para elaborar las grandes plantaciones de caña de azúcar que produce. Tiene telégrafo.

Caraguatay, cuenta además con las importantes poblaciones de Alfonzo Tranquera y San Rafael que van en aumento. 
Piribebuy. - También sobre el río de su nombre, con 10.121 habitantes en todo el partido y telégrafo. Su industria consiste en la agricultura en general y la fabricación de tejidos con especialidad el nombrado poncho PARA-í. Piribebuy fué la tercera capital de la República durante la guerra con la Triple Alianza.

\section{VI.}

\section{Quinto distrito.}

SITUACIÓN, POBLACIÓN, ASPECTO, INDUSTRIA.

El Quinto Distrito pertenece al grupo de los del Norte de la República y aún cuando es el más pequeño en extensión, tiene 31.182 habitantes. Atravesado en su centro de Este á Oeste por la cordillera de los Altos y circunscrito al Sur por la cordillera de Ibicuí y cerros de Ibitimí y Chircal; en su interior se encuentra cubierto de espesos bosques con vegetación exuberante, donde existen diversidad de maderas, especialmente cedros, urundey, lapacho y quebracho, prodigiosos por sus corpulencias; en lo demás son campos, esteros y lomas cubiertas de gramíneas que mantienen gran número de ganados. La industria consiste en la ganadería, la explotación de las maderas y en la agricultura relativa.

División política; partidos; Capital. - Tiene el distrito 5 PARTIDOS.

La capital del distrito y del partido de su nombre es San José, fundado en 1781, por el Gobernador Pedro Melo de Portugal, con el nombre de Dos Arroyos. Tiene telégrafo, productos importantes y una población en todo el partido que no baja de 9.120 habitantes.

Ibitimí.-Situado al pié de los cerros de su nombre y unido á la Asunción por ferro-carril que emplea en el viaje 3 horas y 40 minutos. Tiene una población que no baja de 9.920 habitantes y su principal riqueza es la ganadería, las maderas y el ingenio de azúcar establecido sobre el río Tebicuary-Mí. 
Ibitimí, cuenta además con las poblaciones de Potrero Rojas y el Ingenio "La Azucarera" que van en aumento.

Valenzuela, con 6.140 habitantes y un hermoso templo; Itacurubi de la Cordillera, con 3.019 y telégrafo, y Caballero, con 2.983 y unido á la Asunción por ferro-carril, son partidos de mucho porvenir.

\section{VII. \\ Sexto distrito.}

Situación, población, aspecto, industria.

El Sexto Distrito pertenece al grupo de los anteriores y es el que tiene sólo 19.274 de habitantes, pero en cambio mayor extensión territorial que el tercero y cuarto distrito. Cruzado al Norte por un ramal de la Cordillera de Caaguazú que se dirige hácia el río Paraná, y otro que desprendiendose de la misma, cerca del pueblo de Carayaó, cruza por su centro de Norte á Sur y dá orígen á multitud de vertientes, entre las cuales figuran las del Monday y Tebicuary-Guazú. La parte Este está poblada de espesos bosques, en que abundan árboles de yerba-mate; y la del Oeste se compone de excelentes campos de pastoreo. La ganadería y la elaboración de la yerba-mate son las principales industrias.

División politíca; partidos; Capital. - Comprende 5 parTIDOS.

Ajos. - Situado sobre una hermosa colina que domina sus alrededores, es la capital del distrito y del partido con una población de 6.283 habitantes. Su principal industria consiste en la ganadería.

Ajos, cuenta además con las florecientes colonias Nueva Acstralia, poblada por australianos y 25 DE Noviembre, por nacionales.

Caaguazú. - Con 5.665 habitantes, es uno de los pueblos importantes por su comercio yerbatero, así como San Joaquin, con 2.584, Carayaó, con 2.511 é Ihú, con 2.231. 


\section{-75
VIII.}

\section{Séptimo distrito.}

Situación, población, aspecto, producciones, industria.

El distrito que comprende sólo el partido de Villa Rica se halla situado al Este de la Asunción. En una superficie menor que todos los partidos descritos, contiene 32.297 habitantes. Casi la totalidad de este distrito está cubierto de bosques de ricas maderas, siendo por este motivo exclusivamente agrícola; no tiene sino muy pocos campos de pastoreo, destinados á los animales propios para la labranza. Gran parte de los frutos de la República se producen en su rico suelo, y con especialidad y abundancia el tabaco que es reputado el más excelente. Las producciones son: tabaco, como queda dicho, caña de azúcar, maderas de todas clases, plantas textiles, naranjas, agricultura en general y la mayor parte de los frutos silvestres de la República. La industria consiste en la fabricación de cigarros, vino de naranjas, destilerías de aguardiente, maderas, suelas, recados, tejidos de algodón etc.

Capital. - Villa Rica, situada sobre una colina y rodeada de bosques de naranjos y frescas y exquisitas aguas; es la capital del partido que comprende el Séptimo Distrito. Tiene una hermosa iglesia, un Colegio Nacional, muchos edificios de arquitectura moderna, un buen mercado, importantes casas de comercio, agencia de los Bancos Agrícola y Mercantil. El ferro-carril la une con la Asunción y sólo dista 5 horas.

La hermosa posición en que se encuentra Villa Rica, rodeada de colinas,

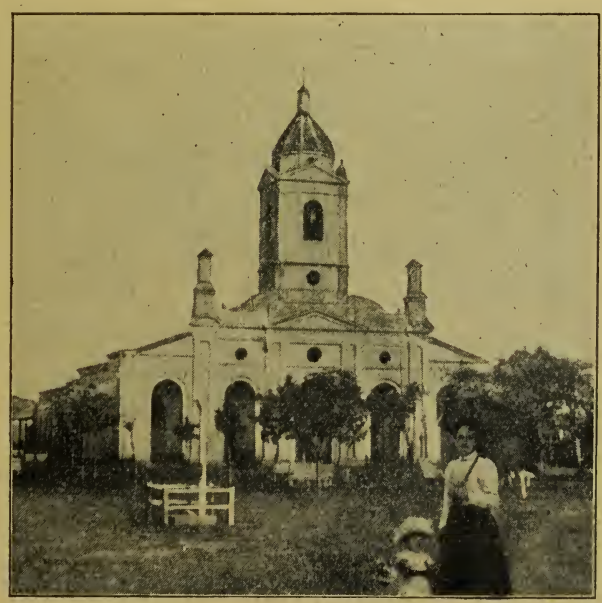

Iglesia de Villa Rica. 
bosques de naranjos y frescos manantiales, hace que su clima sea muy saludable, habiéndose convertido en centro de recreo y lugar de residencia para los que buscan salud ó descanso á sus tareas.

\section{IX.}

\section{Octavo distrito.}

SITUACIÓN, POBLACión, RIQUEZA.

El Octavo Distrito se encuentra al Este de la Asunción con 25.886 habitantes. Sus tierras son bajas hácia el Oeste y Sur, en que predominan los esteros; pero en cambio al Este y Norte, hay grandes bosques que sus laboriosos habitantes lo han convertido en tierras de cultivo. El río Tebicuary-Mí, que limita este distrito, fertiliza admirablemente su suelo. La ganadería y el tabaco constituyen la principal riqueza del partido.

División política; partidos; Capital. - Se encuentra dividido en 4 PaRtidos.

Hiaty.-Con 7.096 habitantes es la capital del distrito y del partido de su nombre. Fué fundado en 1773 por el Gobernador Agustin Fernando de Pinedo. El ferro-carril que la une á la Asunción emplea 4 horas y 40 minutos.

Itapé. - Con 7.830 habitantes, Mbocayaty, con 6.620 y Yataity, con 4.340, son poblaciones importantes por su industria y comercio.

Itapé, tiene también á la población de la Estación de ITApÉ cuyo porvenir de prosperidad no está lejano por la via férrea con que cuenta.

\section{X.}

\section{Noveno distrito.}

SITUACIÓN, ASPECTO, vías DE COMUNiCACIÓN, POBLACIÓN, RiqUEZa.

El Noveno Distrito pertenece al grupo de los del Sur. Su territorio es húmedo y bajo hácia el Sureste, destacándose sin embargo, las importantes colinas de San Juan, Nacaguá, Costa 
Dulce, San Francisco, Santa Ana, Acutí y San Solano; llano y arenoso en el centro y montuoso al Noreste.

La parte Sur que comprende el partido de Caazapá, es uno de los puntos de la República que ofrece los más hermosos campos, profusamente regados por importantes ríos y arroyos, y donde procrean con facilidad toda especie de ganado.

Con excepción de San Juan Nepomuceno, todos los partidos de este distrito, se hallan ligados por ferro-carril. Su población no baja de 28.531 habitantes y la mayor parte del territorio se destina al pastoreo.

División política; partidos; Capital. - El distrito se divide en 4 PARTIDOS.

Tiene por capital á la importante población de Caazapá, con 16.341 habitantes en todo el partido, que fué el primer pueblo fundado por los Jesuitas en 1607, y el templo construido por los mismos, aún existe. La ganadería y la explotación dn sus ricas maderas y el cultivo del tabaco constituyen su riqueza.

Caazapá, tiene además otros centros de poblaciones importantes como Caracará-I, Estación Maciel, Santa Tereza y Estacióx Sosa que por contar con la via férrea, están llamados á ser pueblos florecientes, así como la colonia Cosme.

Ihacanguazú.-Con 5.700 habitantes; Iturbe, recientemente fundado en la Colonia Nacional, con 4.180, y San Juan Nepomuceno, con 2.310, son poblaciones que se dedican á la ganadería, la explotación de maderas y la agricultura.

Ihacanguazú, cuenta además con la población de la Estación BoRJA que está llamado á ser un gran centro por las ventajas del ferro-carril.

\section{$\mathrm{XI}$}

\section{Décimo distrito.}

SITUACIÓN, ASPECTO, PRODUCCIONES, RIQUEZA, POBLACIÓN.

Pertenece al grupo de los distritos del Sureste, sobre el río Paraná. Su suelo presenta en la parte central, y particularmente 
en la confluencia de los ríos Tebicuary-Guazú y Pirapó, grandes pantanos, pero en lo demás está cubierto de abundantes y ricos pastos. Al Norte, Este y Oeste lo bañan ríos y arroyos permanentes; contiene hermosos campos, florecientes colinas que mantienen toda clase de ganados; grandes serranías y ricos bosques de vegetación exuberante, donde existen valiosos yerbales, diversidad de maderas, especialmente cedros prodigiosos por su tamaño, y variedad de animales montaraces, como el anta (mboreví), el jabalí etc. Tiene todo el distrito 28.418 habitantes.

División política; partidos; Capital. - El Décimo Distrito comprende 4 PARTIDos.

La capital del distrito y del partido de su nombre es Yutí, á poca distancia del ferro-carril á Pirapó. Fué el segundo pueblo fundado por los Jesuitas en 1610. Tiene 10.953 habitantes en toda la circunscripción del partido y sus industrias principales son: la ganadería, la yerba-mate y las maderas.

Yutí, tiene otros centros de poblaciones importantes como la Estación Pirapó, Taba-í, Nu Piajhú, Abay y Santa que son de gran porvenir.

Bobi, San Pedro del Paraná y Yegros.-De reciente fundación este último, con $7.974,5.722$ y 3.769 habitantes, respectivamente, son importantes poblaciones que mantienen un activo comercio con Villa Encarnación.

XII.

\section{Undécimo distrito.}

Situación, población, comercio, aspecto, producción, industrias.

Situado este distrito sobre el río Paraná, es el menos poblado de los de este grupo, pues sólo cuenta con 22.978 habitantes; pero en cambio es el más comercial.

El aspecto físico de esta región es muy variado, al Oeste se bifurca en varios ramales la cadena de montañas que más al Norte tiene el nombre de Caaguazí; al Este, el terreno es poco 
accidentado y presenta ricos yerbales explotados desde la época de la conquista, y en su interior está regado por inumerables arroyos que vierten sus aguas en el Paraná.

La industria de este distrito consiste en la yerba-mate, la explotación de maderas y la ganadería.

División política; partidos; Capital. - Está dividido en 4 PARTIDOS.

La capital es Villa Encarnación, que es á la vez del partido de su nombre con 12.496 habitantes. Se encuentra situada sobre el río Paraná frente á la ciudad argentina de Posadas. Es la $2^{a}$ aduana de la República. Tiene un Colegio Nacional.

Villa Encarnación, tiene además otros centros de poblaciones importantes, como Puerto Alegre, Tacurú-pucú y Villa Azara, que por encontrarse todos ellos sobre el río Paraná, están llamados á prosperar rápidamente.

San Cosme.-También sobre el río Paraná con 6.118 habitantes, es una población importante por su riqueza ganadera.

San Cosme, cuenta además con la población de Cai Puente, que prospera diariamente.

Jesús y Trinidad y Cármen del Paraná- - Son poblaciones que van prosperando. El primero tiene 2.833 habitantes y el segundo, 1.531.

Jesús y Trinidad, cuenta también con la colonia Hohenau.

XIII.

\section{Duodécimo distrito.}

SitUACIÓN, INDUSTRIAS, PRODUCCIÓN, ASPECTO, POBLACIÓN.

Esste distrito, situado al Sur de la República y conocido pol Misiones, es eminentemente pastoril y los productos de sus grandes rebaños de ganado vacuno, caballar y lanar, constituyen su principal riqueza. Su suelo, de Norte á Sur, está cruzado por las ramificaciones de la cordillera de Caaguazú y en el Este y Oeste, 


\section{$-80-$}

en general, ofrece un aspecto llano, cubierto de excelentes pastos, multitud de arroyos y grandes esteros.

\section{El Duodécimo Distrito tiene 30.365 habitantes.}

División política; partidos; Capital. - Se divide el distrito en 7 PARTIDOS.

San Ignacio. - Capital del distrito y del partido de su nombre, con 5.121 habitantes. Fué la antigua capital de las Misiones Jesuíticas; posée un hermoso templo de tres naves con cinco altares tallados y dorados; sus pinturas datan del año 1683 y como obra de arte son dignas de ser vistos.

San Juan Bautista. - Sobre una colina presentando un risueño panorama, es un pueblo importante. Posée todo el partido 7.224 habitantes.

Santiago. - Con 6.281 habitantes en todo el partido. Su templo, hoy en estado ruinoso, fué también obra de los Jesuitas y semejante al de San Ignacio.

San Miguel.-Con 3.801 habitantes; Santa Rosa, con 3.065, fué la primitiva capital de las Misiones Jesuíticas, llegando entónces á ser una de las poblaciones más florecientes; Santa Maria, con 2.848 habitantes, posée un templo de construcción antigua y un pozo de agua, notables obras de los Jesuitas, y finalmente Villa Florida sobre la margen izquierda del río Tebicuarí con 2.025 habitantes, fundada en 1880 , es un pueblo que prospera rápidamente.

\section{XIV. \\ Décimotercio distrito.}

Situación, POBlación, aSPECTO, PRODUCCIONES, RIQUEZa.

Situado este distrito, también al Sur de la República, con una población que no baja de 22.535 habitantes; el suelo se extiende en un valle formado por los ramales de la cordillera de los Altos, presentando vastas llanuras regadas por los ríos Tebicury-Mi y Tebicury-Guazú. Sus producciones consisten en 
ganados, buenos pastos, particularmente en la Cordillerita de Ibicuí, maderas, hierro, kaolin y manganeso.

División polí́tica; partidos; Capital. - El distrito comprende 3 PARTIDOS.

La capital es Ibicui, fundada en 1766 . Tiene un fuerte comercio con la Asunción y 10.253 habitantes en todo el partido.

Mbuyapey.-Con 5.912 habitantes y Quiquió, con 5.820, son poblaciones que se dedican exclusivamente á la ganadería.

\section{$\mathrm{XV}$.}

\section{Décimocuarto distrito.}

SiTUaCión, POBLaCión, ASPECTO, VÍAS DE COMUNICACión.

El Décimocuarto Distrito que forma parte del grupo de los del sur, tiene 30.454 habitantes. Su suelo es parecido al anterior, con hermosos campos que mantienen muchos ganados, y grandes bosques que proporcionan buenas maderas y gran variedad de árboles frutales.

El rio Tebicuary-Mi que lo limita, es navegable.

División política; partidos; CaptTal. - Tiene el distrito 3 PARTIDOS.

La capital es Quindy, con 11.943 habitantes, fundada en 1733. Tiene télegrafo y muchas casas de comercio de relativa importancia.

Acahay. - Con 11.798 habitantes y Caapucú con 6.713 , son poblaciones ricas en ganadería.

\section{XVI.}

Décimoquinto distrito.

situactón, aspecto, producciones, RiqueZa, poblactón.

También este distrito pertenece al grupo de los del Sur. Su suelo, particularmente el que comprende Paraguarí, goza de justa fama como pintoresco por la variedad de sus panoramas. Al 


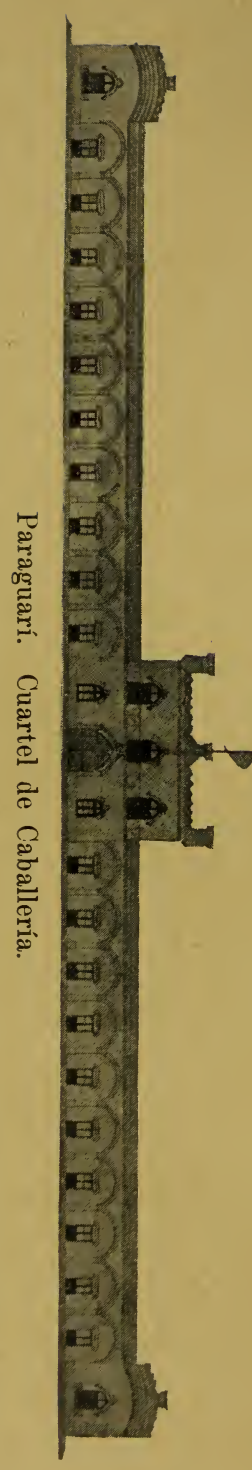

Noreste se destaca la faja obscura de la cordillera de los Altos, de donde se desprenden tres ramales que terminan aquí: son los cerros de Santo Tomás, Ihú y Mbatoví; al Noreste, una parte del valle de Pirayú que termina en el cerro de Paraguarí y al Sureste y Sur inmensas llanuras regadas de importantes arroyos. Tiene ricas producciones como piedras de construcción, maderas de todas clases y tabaco, pero la ganadería es su principal riqueza.

La población es de 38.822 habitantes.

División política; partidos; Capital. Comprende 4 PARTIDOS.

Tiene por capital á Paraguari situado en el extremo Este del delicioso valle de Pirayú con unos 10.328 habitantes en todo el partido. Posee buenos edificios y el hermoso Cuartel de Caballería que pronto habrá terminado. A pocos kilómetros se encuentra el cerro Porteño, llamado así por que allí acampó el ejército argentino al mando del General Belgrano, en 1811. Está unido á la Asunción por ferro-carril que sólo dista 2 horas y $25^{\prime}$.

Paraguarí fué el sitio donde los Jesuitas tenían establecida una gran estancia con ganados.

Carapeguá. - Con 15.334 habitantes en todo el partido; no tan sólo es más importante en población que el antérior, sino que la feracidad de sus tierras y lo fertilísimas de sus llanuras, colocan á este partido como uno de los primeros en agricultura y ganadería; siendo el tabaco su principal producción.

Tabapy.-Con 8.820 habitantes á 16 kilómetros Sur del anterior y Escobar con 4.140 recientemente fundado, con ferro-carril que cruza el partido, son poblaciones agrícolas. 


\section{$-83-$
XVII.
osexto distrito.}

SITUACIÓN, POBLACIÓN, VIABILIDAD, ASPECTO, PRODUCCIONES, RIQUEZAS.

Fste distrito por su población, que no pasa de 28.608 habitantes, es el menos importante de los tres distritos que constituyen el grupo de los centrales, pero en cambio aventaja á todos los demás por ser el único que tiene todos sus partidos cruzados por el ferro-carril y hallarse más cerca de la capital. Su suelo es en general fértil, produciendo mejor que en otros, el tabaco, caña de azúcar, mandioca, etc. Hacia el Este, se extiende una llanura formada por el valle de Pirayú, cubierta de pastos donde se alimentan todas clases de ganados. Sus cerros y colinas encierran valiosas piedras de construcción.

División política; PARtidos; Capital. - Se encuentra dividido en 4 PARTIDOs.

Itauguá. - Con 8.820 habitantes, es la capital del distrito y del partido de su nombre; tiene casas comerciales importantes, producciones é industrias de mucho valor, como el tabaco y la fabricación de tejidos de algodón. El ferro-carril lo une con la Asunción.

Pirayú.-Situado en el valle de su nombre, con 8.620 habitantes en todo el partido, siendo su riqueza principal la agricultura y la fabricación de ladrillos y tejas. En el paraje "Ascurra" subsiste aún una gran parte de las trincheras de piedras construidas durante la guerra con la Triple Alianza. Está unido á la Asunción por ferro-carril que dista 1 hora y 45'.

Areguá. - Sobre una pintoresca colina, llamado el jardín de los asuncenos, por la incomparable hermosura de sus aspectos naturales y la fecundidad de su privilegiado suelo. La riqueza de este partido constituye sus puras y saludables aguas, sus tierras aptas para la fabricación de ladrillos y tejas y más que todo, para la agricultura. Areguá fué fundado en 1538 por Domingo Martínez de Irala; tiene 6.617 habitantes en todo el partido y dista 1 hora de la Asunción por ferro-carril.

Ipacarai. - Con 4.663 habitantes, es uno de los pueblos que se encuentran sobre la vía férrea de más porvenir. Es el emporio del comercio de los pueblos de la cordillera. 


\section{$-84-$}

\section{XVIII.}

\section{Decimoséptimo distrito.}

Situación, IMPORTANCIA, POBLACIÓN, ASPECTO, PRODUCCIONES.

El Decimoséptimo distrito, cuyos partidos circundan á la Asunción, es uno de los más importantes de la República, porque en una extensión veinte veces menor que el segundo distrito, tiene igual población ó sea 37.435 habitantes.

Su suelo está cubierto de bosques surcados por arroyos y arroyuelos que dan vida á todas las grandes plantaciones de cereales, caña de azúcar, tabaco, arroz, maiz, mandioca, limones, guayabos, etc.

División política; Partidos; Capital. - El distrito se divide en 6 PARTIDOS.

La capital es Luque, con 16.501 habitantes en todo el partido; tiene un ingenio de azúcar é industrias importantes. Está unido á la Asunción por ferro-carril, por telégrafo y por teléfono. Luque fué la segunda capital de la República durante la guerra con la Triple Alianza.

San Lorenzo del Campo Grande.-Con 9.208 habitantes, unido á la Asunción por tramway á vapor y teléfono. La agricultura es su principal industria.

San Lorenzo de la Frontera.-Con 5.419 habitantes, Limpio con 5.812 y San Antonio con 1.600 y telégrafos, son poblaciones industriosas de gran porvenir por hallarse en los alrededores de la Asunción.

San Lorenzo de la Frontera, tiene también á la población de Arroyo Seco que prospera.

Villa Hayes que comprende este distrito, se describe al tratar de la Región Occidental.

\section{XIX.}

\section{Décimooctavo distrito.}

SitUACIÓN, IMPORTANCIA, POBLACIÓN, ASPECTO, PRODUCCIONES.

Es el tercero de los que componen el grupo de los centrales y el más importante por su población que no baja de 38.633 habitantes. 
El suelo es, en gran parte, análogo al anterior, con ricos bosques de naranja agria.

División política; partidos; Capital. - Está dividido en 5 PARTIDOS.

Tiene por capital á Itá, el segundo pueblo establecido por Juan de Ayolas en 1536, con los indios guaraníes llamados antiguamente Carios que fueron vencidos en la memorable batalla de Guarnipitán. Posee un templo tan antiguo como su fundación, con pinturas notables de los Jesuitas, telégrafo y 12.329 habitantes, que se dedican á la agricultura y á los trabajos de alfarería y fabricación de hamacas.

Capiatá.-Con 11.395 habitantes, es una de las poblaciones de la República más ricas en la agricultura.

Yaguarón.-Con 7.713 habitantes, es también uno de los pueblos fundados por Juan de Ayolas en 1536. Sus tierras, sumamente feraces, son aptas para el desarrollo de toda clase de cultivos y de la ganadería. La fabricación de esencias de hojas de naranja agria y la agricultura constituyen su industria. Tiene Yaguarón telégrafo y un templo construido por los Jesuitas, notable por sus pinturas artísticas.

Guarambaré.-Con 3.615 habitantes, posée telégrafo é Ipané con 3.481, son poblaciones que se dedican con especialidad al cultivo del arroz.

XX.

\section{Décimonono distrito.}

SituACIÓN, POBLACIÓN, ASPECTO, PRODUCCIONES, RIQUEZA.

El Distrito Décimonono, es el menos poblado de los fluviales del Sur de la Asunción.

En una superficie diez veces mayor que el anterior distrito, contiene 16.563 habitantes.

Su suelo, desde el Pikisiry al Norte ofrece hacia el interior una serie de ondulaciones formadas de pequeñas colinas muy pin- 
torescas, cubiertas de pastos; sobresaliendo entre ellas las Lomas Valentinas, célebres por sus recuerdos históricos en la guerra pasada; al Sur desde el Pikisiry, presenta al Este grandes bañados, hasta confundirse con el lago Ipoá, y al Suroeste y Oeste extensos palmares y bosques en los cuales abundan ciervos, venados, avestruces, tigres, leones, etc. Su principal riqueza es el ganado vacuno que no baja de 125.000 cabezas.

División política; paRtidos; Capital.-El Décimonono Distrito comprende 4 PARTIDOS.

Villa Oliva_-Con 3.504 habitantes sobre la márgen izquierda del río Paraguay, es la capital del distrito. Fué fundado en 1845 por el gobierno de Carlos A. López. La cria de ganado vacuno es su principal industria. Tiene telégrafo.

Villeta.-También sobre el río Paraguay, con 9.518 habitantes en todo el partido. Es la $5^{a}$ aduana de la República. Villeta progresa de día en día.

En su puerto se embarcan anualmente millares de naranjas para el Plata.

Villa Franca.-Con 1.941 habitantes se encuentra sobre el río Paraguay. Tiene telégrafo, siendo la ganadería su principal industria.

Villa Franca tiene también á Vilua Fravca Nueva que es una población importante, por encontrarse sobre el río Paraguay y frente á la ciudad argentina de Formosa; así como la colonia Sebastian Gaboto sobre el mismo río.

XXI.

\section{Vigésimo distrito.}

SITUACIÓN, IMPORTANCIA, POBLACIÓN，ASPECTO, INDUSTRIA, RIQUEZA.

Este distrito es el último de los fluviales del Sur y tan importante como el segundo distrito en población, que asciende á 
37.193 habitantes. Su suelo ofrece terrenos llanos, fertilizados por abundantes arroyos; hermosos bosques que dan á la industria variadas maderas de ebanistería y ricos campos en que pastan más de 240.000 cabezas de ganado vacuno.

División política; partidos; Capital. - Se divide el distrito en 11 PARTIDOS.

La capital es Villa del Pilar con 6.697 habitantes en todo el partido, pueblo hermoso situado sobre el río Paraguay y rodeado de árboles de naranjos. Es la $4^{a}$ aduana de la República. Durante los primeros años de la dictadura de Francia, Villa del Pilar tuvo el privilegio de ser el único puerto de la República habilitado para el comercio del exterior.

Villa de Humaitá. - También sobre el río Paraguay con 5.820 habitantes en todo el partido. Es la $7^{\text {a }}$ aduana de la República, con gran actividad comercial. Fué la antigua fortificación que sirvió de barrera tenaz contra las fuerzas aliadas.

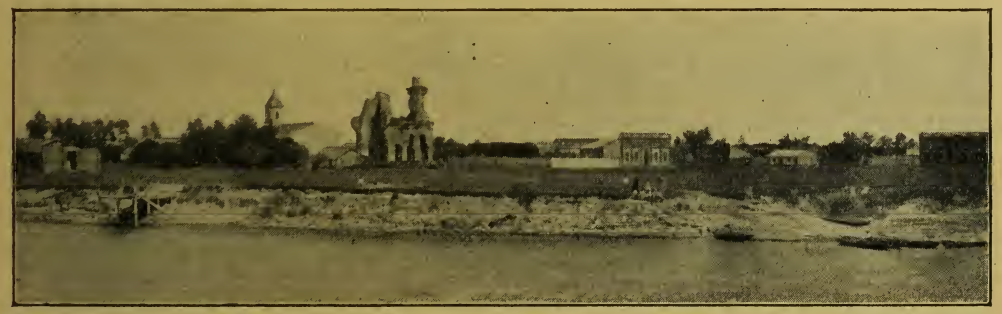

Villa de Humaitá.

Paso de Patria. - Con 1.745 habitantes y Yabebiry con 2.322 y puertos sobre el río Paraná, son centros de población que prosperan, lo mismo que Isla Umbú con 3.445 habitantes, Laureles con 2.819, Tacuaras con 2.614, Desmochados con 3.225, Pedro González con 3.516, San Juan Bautista de Ñembucú con 2.441 y Guazucuá con 2.517, situados en el interior y ricos en ganados. 


\section{TERCERA PARTE.}

\section{REGIÓN OCCIDENTAL ${ }^{(1)}$ ó GRAN CHACO.}

\section{Orígen del nombre Chaco.}

La región que describimos era conocida, antes de la conquista española, con el nombre de Yacú que le dieron los guaraníes por la abundancia de las pavas del monte conocidas con aquel nombre y que habitan esta región.

Posteriormente fué modificada en su pronunciación por los españoles llamandóle Chacú y hoy Chaco como acontece con muchos términos del idioma guaraní.

\section{Caracteres generales.}

Límites. - Al Norte, el curso del río Negro que desemboca en el río Paraguay á 5 kilómetros Norte de Bahía Negra, sigue el curso del río Negro y Otuquis, pasa por la cumbre de la cordillera del Chochis hasta la naciente del río Parapití, que lo separa de Bolivia; al Sur y Suroeste, el río Pilcomayo, que lo limita de la Argentina y Bolivia respectivamente; al Oeste, el curso del mismo río Parapití hasta el paralelo $19^{\circ} 30^{\prime}$ y de aquí una línea terrestre que de Norte á Sur termina en el río Pilcomayo, que lo separa también de Bolivia; al Este, el río Para-

(1) Apéndice 24 . 


\section{$-89$}

guay que lo divide primeramente del Estado brasileño de MattoGrosso y luego de la Región Oriental del Paraguay.

Perimetro. - Su perímetro es de 2.425 kilómetros, de los cuales unos 1.980 son de costas fluviales y los 445 restantes, de línea terrestre.

SUPERFICIE. - 277.000 kilómetros cuadrados aproximadamente.

Costas. - Las más extensas son las del río Pilcomayo que no bajan de 800 kilómetros; sobre el río Paraguay 730; las del río Parapití 250; y 200 en los ríos Negro y Otuquis: total 1.980 kilómetros.

Población.-25.000 habitantes y unos 100.000 indios salvajes, divididos en distintas tribus de las cuales son las principales: los tobas, lenguas, pilagáes, angaistés, sanapanás, sapuchís, tumanahás, chamacocos y guanáes.

Aspecto general. - La inmensa Región Occidental ó Gran Chaco descubierta en la parte Septentrional por Juan de Ayolas en 1536-1538 y por Domingo Martínez de Irala en 1548, presenta una llanura cálida y húmeda, levemente inclinada de Noroeste á Sureste, cubierta de GRAmíneas, espesos bosques regados por ríos y grandes extensiones de anegadisos, de los cuales algunos son potables y otros nó. Las mayores elevaciones se encuentran sobre las márgenes del río Paraguay en donde se hallan establecidas las poblaciones de Bahía Negra, Fuerte Olimpo, Puerto Casado, Puerto Stanley, Villa Hayes y otros.

Orografía.-El sistema orográfico de la Región Occidental ó Gran Chaco puede considerarse formado por la cadena de montañas que se conoce con el nombre de Cerro Deu Chochís y por las últimas ramificaciones de los sistemas de Aunumay y MbaraCAYú de la Región Oriental. La primera procede de Bolivia.

La cadena del Cноснís, que forma el límite Septentrional de una parte de esta región, se extiende unos 260 kilómetros bifurcando barras aisladas entre ellas, al Sur, el grupo de cerros llamados Carandaytr, Tamané y Observación. Otro grupo de 
colinas, al Este de estos, son conocidos por Cerro Irala, Cerro San Miguel y Cerro Miguelito.

De las r:amificaciones de Amambay, se encuentra un pequeño grupo de colinas llamado Cerros de Galván, como á 17 kilómetros al Oeste de Puerto Casado. A menos de 4 kilómetros Oeste de Puerto Celina, se levanta otro grupo conocido por LaS Siete Cabezas. Al Suroeste, inmediato á Fuerte Olimpo, están las Tres Hermanas y un poco más al Norte como á 3 kilómetros, terminan todos estos grupos con dos pequeñas elevaciones, de las cuales la más alejada, que es la mayor, se conoce por Cerro DEL Norte. Todas estas colinas se encuentran sobre la márgen derecha del río Paraguay y sin conexión aparente con las de la Región Oriental.

La cordillera de los Altos, que es una de las subramificaciones del sistema de Mbaracayú termina en Villa Hayes con las colinas de su nombre y con el cerro conocido por Confuso.

Hidrografía. - Los principales ríos de esta región, son: el Pilcomayo, el Parapití, el Otuquis, el Negro y el Galván.

El Pilcomayo, nace con dos brazos principales, el río Surpacha y el río Pilayá que tienen sus fuentes en Tarija (Bolivia). Desde la confluencia de ambos ríos en las cercanías del pueblecito Juntas, toma el río resultante el nombre de Pilcomayo; corre describiendo un gran arco hacia el Sureste por terrenos llanos y hundidos, y, ora se convierte en grandes bañados y lagunas ó penetra en extensas selvas, sin que sea posible determinar fijamente su curso, hasta desembocar en el río Paraguay frente al cerro de Lambaré. Su extensión es de 2.000 kilómetros, de los cuales unos 800 kilómetros riegan esta región.

El río Pilcomayo se ha hecho notable desde mucho tiempo atrás, y sobre todo en la época actual, por los repetidos esfuerzos de audaces exploradores que han intentado su navegación para hacerlo servir á la comunicación con Bolivia por el río Paraguay, atrayendo así las ricas y rariadas producciones de aquella región. Pero los trabajos en pro de esta idea, cuya realización habría cambiado en poco tiempo la faz económica de ambos pueblos, no han dado hasta hoy resultados satisfactorios. 
La primera y única exploración del Pilcomayo, llevada á cabo con éxito completo, es la del capitán Nuflo de Chaves que con treinta compañeros, remontó en Mayo de 1546, en canoas hasta descubrir las tierras del Perú.

El Parapití, tiene su orígen en la Serranía de Chimbé de Bolivia, corre generalmente al Norte, sirve también de frontera á esta región en una extensión de 250 kilómetros y luego penetra en el territorio de su nacimiento.

El río Otuquis, tiene sus fuentes en las faldas meridionales de la cadena de montaña del Chochís, se dirije al Este y luego al Sureste hasta perderse en la gran rebalza de Bahía Negra alimentando una serie de pequeñas lagunas.

El río Negro que puede considerarse como la continuación del Otuquis, nace de las mismas lagunas y se dirije al Sureste recibiendo en su curso el río VERDE, en cuya orilla se encuentra situado el fortín "Galpón».

El río NEGRo fué explorado en 1853 por el comandante Th. Page, quien con el vapor WATER-WITch de 150 caballos de fuerza y mediante la autorización del gobierno de Carlos A. López, logró remontar hasta una distancia de 36 millas, siéndole imposible seguir adelante, no por falta de agua, sino por hallarse el cauce del río interrumpido por camalotes.

El comandante Page traía la misión del gobierno de los Estados Unidos, de estudiar los ríos del Chaco, tarea que no pudo realizar por los inconvenientes que aquellos ofrecian dadas las condiciones del WATER-W

Los ríos Galván, Seco, Michi, Aguaray, Verde y Confuso, afluentes todos del río Paraguay, se forman de las vertientes interiores y corren generalmente al Este, siendo la mayor parte de ellos navegables hasta ciertas distancias, particularmente en la época de las lluvias.

Clima.-El clima está determinado por dos estaciones, la seca y la lluviosa. Las lluvias se producen generalmente desde Octubre hasta Mayo. El invierno que dura los 4 meses restantes, es seco. Los rocíos son abundantes. La temperatura media del litoral del río Paraguay, es aproximadamente de $24^{\circ}$ centígrados, estando sujeta á la influencia de los vientos Norte y Sur, como en la región Oriental.

El calor y la humedad la hace más fértil á esta región. 
Producciones. - Las producciones son análogas á las de la región Oriental, debiendo agregarse el gran desarrollo y abundancia de las palmeras, del quebracho, del algarrobo, del sauce, del palo santo, del palo de rosa, del algodón y la uva silvestre. En cambio escasean los árboles de los terrenos altos y sedimentados.

De los anivales puede decirse que son también análogos, abundando el monito ó miriquiná, el jaguar ó tigre, los jabalíes, los ciervos, las víboras, el avestruz, los yacús y los insectos de todas clases.

De los Minerales, sólo se sabe que existen grandes salinas en el interior.

Industrias. - La explotación de extracto de quebracho que está despertando un gran interés en el Río de la Plata, obrajes de maderas diversas y palmas y la agricultura en los centros de poblaciones, pero la ganadería es la principal riqueza de la región Occidental.

Fuertes militares. - Villa Hayes, Fuerte Olimpo y Bahía Negra, sobre el río Paraguay y muchos fortines diseminados en distintos puntos, entre ellos: el Patria y GaLpón sobre el río Negro y río Verde y el Ferreira, de Oro y otros en las cercanias de Villa Hayes.

El Fuerte Olimpo, antiguamente llamado Borbón, por la dinastia reinante en España cuando se creó, es uno de los fuertes más importantes con que cuenta la región Occidental. Se encuentra emplazado sobre un cerro, inferior en elevación á otro que se halla próximo al Suroeste. Fué fundado por real órden de Carlos III de España á fines del siglo XVIII con el objeto de protejer la frontera Norte del virreinato del Río de la Plata contra los ataques de los portugueses de Matto-Grosso y las invasiones de los indios del Chaco.

La fortaleza está formada por un cuadrilátero de modesta arquitectura y poca elevación, cuyos ángulos se hallan defendidos por un bastión semicircular con varias troneras y su correspondiente garita.

Un murallón, como de 4 kilómetros de extensión, defiende la fortaleza por la parte del interior.

En la Plaza de Armas de la fortaleza existe grabada una piedra granítica con la siguiente inscripción: 
“Restablecióse este Fuerte Olintro el 21 de Agosto de 1856 bajo el comando de los ciudadanos Marcelino Antonio Coronel y José Manuel GMḾ́xez. 》

Poblaciones importantes. - Villa Hayes sobre el río Paraguay á 35 kilómetros Norte de la Asunción, es uno de los pueblos de esta región que prospera rápidamente. Tiene un sólido cuartel, edificios de construcción moderna, calles anchas y casas de comercio regularmente surtidas.

En sus alrededores existen lindas quintas y chacras formadas por los colonos franceses y alemanes que la poblaron. La ganadería y la agricultura son la riqueza de Vimia Hayes.

Villa Hayes fué fundada en 1855 por el gobierno de Carlos A. López, bajo el nombre de Villa Burdeos, con colonos franceses que se dispersaron. Terminada la guerra, fuerzas argentinas la ocuparon y le dieron el nombre de Villa Occidental. Más tarde, habiendo sido reconocido á favor del Paraguay el derecho á este territorio por el fallo arbitral del Presidente de los Estados Unidos de Norte América, Rutherford V. Hayes se le dió la denominación actual de Villa Hayes, por ley del 13 de Mayo de 1879.

Fuerte Olimpo.-A 465 kilómetros Norte de la anterior, se encuentra rodeado de una población que va en aumento por los importantes establecimientos industriales y ganaderos que le circundan.

Bahía Negra.-A 135 kilómetros Norte del anterior, sobre una de las barrancas más elevadas del río Paraguay, también progresa día á día por los establecimientos industriales y ganaderos que le rodean.

Vienen después un sin número de poblaciones sobre el mismo río Paraguay desde la desembocadura del río Pilcomayo hasta Bahía Negra, que unos son establecimientos ganaderos y otros los llamados oBRaJes ó grandes depósitos de maderas y palmas extraidas de los montes para la exportación, así como muchas fábricas de ladrillos y tejas, pero los más importantes son las fábricas de extracto de quebracho en Puerto Casado y Puerto Sastre, que están llamados á ser los primeros pueblos de la región Occidental. 
Finalmente, merece mencionarse las Misiones Evangélicas establecidas bajo el Patronato del Gobierno Nacional en el año 1892.

En una extensión que no baja de 300 kilómetros cuadrados, los misioneros han establecido en poco tiempo, colonias, estancias, reducciones y muchos pozos de agua dulce, llegando al presente á comunicarse con más de 3.000 indios, de los cuales han sido convertidos y catequizados más de la mitad.

La primera reducción á 150 kilómetros Oeste de Villa Concepción en las tierras del cacique Mechí, y la más avanzada á 220 kilómetros, en las tierras de Suhin, son las más importantes poblaciones de las misiones.

Estas reducciones cuentan con dos iglesias, una escuela de niños con 100 alumnos y las estancias "Waikyathlatamyalwa» y "El Pozo».

Tienen además establecida una colonia de indios completamente reducidos y muchas otras estancias de particulares bajo el cuidado y vigilancia de los misioneros. 


\section{CUARTA PARTE.}

\section{DESCRIPCIÓN POLÍTICA.}

I.

\section{Razas.}

Como todas las naciones de la América Española, el Paraguay fué poblado por los descendientes de los conquistadores íberos y por los naturales ó aborígenes que habitaban sus selvas primitivas.

Del cruzamiento de estas razas se formaron los elementos étnicos de la población que han producido los tipos de mestizos y mulatos. Aquellos proceden de la mezcla de los blancos con los naturales; éstos, de la unión de los blancos ó de los naturales aborígenes con los negros.

El orígen de la raza paraguaya, puede decirse que data de 1540 , y se produce con la histórica conspiración de los indios guaraníes contra el gobernador Irala, el juéves santo de aquel año.

Los españoles trataban de celebrar una procesión de flagelantes con solemnidad y pompa para infundir la obediencia por medio de las prácticas religiosas.

Los guaraníes eligieron esta oportunidad para intentar el exterminio de los conquistadores, cuya tiranía empezaba á despertarles deseos de venganza, librándose de la esclavitud que les enrostraban las otras tribus no sometidas, y que disputaban y combatían en defensa de su hogar, su suelo é independencia á los conquistadores. Extraña casualidad libró á los españoles de-una muerte cierta: una jóven india, hija de uno de los caciques 
más renombrados, mantenía relaciones amorosas con el capitán español Juan de Salazar, y viendo el peligro que corría, no solamente su amante sino ella misma, corrió á informarle de la conspiración. Los españoles simularon en el acto, que una partida de indios del Chaco venía á atacarlos y convocaron á los caciques principales, con el pretexto de consultarles las medidas que debían tomarse.

Estos concurrieron al punto, entraron al Fuerte y obligados á confesar sus intenciones, fueron sacrificados. Aquella represión vigorosa y atrevida, quiso Irala dulcificarla con un acto de mansedumbre y prudencia, y fué entónces que para sellar la conciliación con los vencidos, decretó la unión de los principales españoles con las indias.

El historiador Funes comentando aquel suceso se expresa en estos términos :

«El gobernador Irala hizo admirar en esta ocasión para los incautos su humanidad. Arrodillados los indios á sus pies, obtuvieron toda misericordia. Esta reconciliación fué sellada por el matrimonio de algunas indias con los españoles. De la unión de estos pueblos derivan los mestizos; unión que debe ser ventajosa, si es verdad que los hombres ganan como los animales, atravesando sus razas; pero siempre era de desear, que así como los hombres tienen un solo orígen, tuviesen también, si fuese posible, una sola patria, para que no se conservase ninguna semilla de esas antipatías nacionales que eternizan las guerras y las pasiones destructoras.»

El núcleo de los habitantes de las principales ciudades, como Asunción, Villa Rica, San Pedro, Paraguarí, Villa del Pilar, Luque, Itauguá, Limpio, Villeta, Villa Olivia, Humaitá, Villa Concepción, etc., etc., está formado por los descendientes de los conquistadores que mantienen más ó menos pura ó mezclada la sangre española.

La raza paraguaya, obedeciendo á las diversas influencias de la naturaleza y al concurso de la inmigración europea ha ido modificándose. Leyes benéficas de estímulo y protección al extranjero, facilitan su entrada al país y llega á radicarse ventajosamente. La raza blanca señala su predominio sobre las demás; y en todas partes puede verse confundido y asimilado á la población nacional, el italiano, francés, español, alemán, inglés, suizo, austríaco, etc.

Los naturales habitan los pueblos de Ipané, Guarambaré, Itá, Yaguarón, Atirá, Altos, Tobatí, Belén, San Estanislao, San Joaquín, Itapé, Caazapá, Yutí, Santa María, Santa Rosa, San Ignacio, Santiago, San Cosme, Jesús y el Carmen, que de la antigua Comunidad de Itapuá, hoy Villa de la Encarnación, se ha formado y establecido entre el Caraguatá y el`Tacuarí. 
Estas poblaciones son las que bajo el nombre de REDUCciones fundaron los Jesuitas con los naturales, y es de notar que en algunas, como Itá, Itapé, Yaguarón, Guarambaré, Atirá, Tobatí é Ipané conservan todavía los rasgos de los primitivos habitantes, que en otras van desapareciendo paulatinamente por la absorción de la población blanca ó criolla.

Los indios naturales que habitaban los veinte y un pueblos citados, vivieron desde el principio humillados y abatidos, víctimas de abusos, privaciones y arbitrariedades, bajo la dura servidumbre constituida por el régimen de la conquista, hasta que por decreto del gobierno de Carlos A. López de fecha 7 de Octubre de 1848, fueron declarados ciudadanos.

Los indios ó naturales que habitaban el país que hoy forma la República del Paraguay, eran los guaraníes. Se extendían sobre un vasto territorio, divididos en numerosas tribus, entre las cuales, los payaguaes dominaban con su flotilla de canoas el río Paraguay desde la laguna de los Xarayes hasta más abajo de su unión con el Paraná.

Las principales tribus de la nación guaraní que habitaban el territorio comprendido entre los ríos Paraná y Paraguay eran los Imbeguaes, Corondaes, Calchaquíes, Caracaraes, Tucaes, Timbúes, Curupaitíes, Tarumaes y Caiguaes; y los de la nación payaguá, los Cadiques y Stacuaes, conocidos también los primeros con el nombre de Sariguaces, y los segundos, con el de Agaces ó taCUMBUes.

Los guaraníes, debido á la docilidad de su carácter, fueron en gran parte sometidos por los conquistadores, á diferencia de otras naciones indígenas que se mostraron refractarias á la conquista, siendo esta la causa de su casi total destrucción.

La única tribu de la nación guaraní que subsiste aún en estado salvaje, es la de los caiguáes, que habita el Noreste de la parte oriental de la República y vive pacíficamente, manteniéndose de la caza y del cultivo de los frutos más indispensables para la vida, tales como el maíz, la mandioca, etc.

También algunos indios trabajan con los yerbateros en la elaboración de la yerba-mate.

Decoud, Geografía. 
Los Tobas, Lenguas, Pilagáes, Angaistés, Sanapanás, Sapuchís, Tumanahás, Chamacocos y Guanaes, vagan por los inmensos desiertos del Departamento Occidental ó Gran Chaco.

Los negros y mulatos componían los pueblos de Emboscada, Tabapy y Areguá.

La población negra sometida á la esclavitud, era reducidísima en comparación con la de otras regiones de orígen español, y estaba circunscrita antes de la guerra á los citados pueblos. Hoy ha desaparecido casi completamente.

La poca extensión é importancia de la raza negra, es debido á que el Paraguay ha sido quizás uno de los pocos países de América que no contaba con la explotación de minas ó ingenios, donde la necesidad de abundantes brazos motivara un numeroso comercio de negros africanos, orígen de la densidad de aquella raza en casi todos los países del nuevo mundo. En el Paraguay sólo fueron introducidos para el servicio doméstico.

Aquí empezó la esclavitud propiamente dicha, con la introducción de los pocos negros africanos durante la conquista. El $1^{\circ}$ de Enero de 1843 , el gobierno de Carlos A. López declaró libre los vientres de las esclavas, y sus hijos que nacieren en adelante, debían de llamarse "Libertos de la República del Paraguay». Posteriormente, la esclavitud fué abolida para siempre por decreto del gobierno provisorio de la República de fecho 2 de Octubre de 1869, ratificado por el artículo 25 de la Constitución Nacional.

II.

\section{Lenguaje.}

El idioma oficial de la República es el español.

El guaraní (1), idioma de los primitivos habitantes de esta región, es muy general aún, especialmente en las poblaciones del interior, reconociendo por causa el sistema despótico de gobierno á que estuvo sujeto el Paraguay durante el largo período de Francia y los López.

Los indios todavía en estado salvaje, esparcidos tanto en la parte oriental como en la occidental de la República, hablan sus idiomas propios, que por lo general llevan el mismo nombre de las respectivas tribus.

(1) Apéndice 25. 


\section{$-99-$ \\ III. \\ Religión.}

La religión del Estado es la católica, apostólica, romana con tolerancia de los demás cultos.

\section{IV.}

\section{Población.}

Según los datos estadísticos de 1899, se ha calculado la población del Paraguay en 635.571 habitantes, pero admitiendo omisiones probables en los trabajos censales que pueden computarse en un $5 \%$ á que se agrega el crecimiento vegetativo, puede calcularse aproximadamente en 667.349.

Comparando el aumento de población de 1899, con la que contaba en 1887, se obtiene aproximadamente, para fines del año 1905, unos 700.000 habitantes, sin comprender los indios salvajes de la región Occidental ó Gran Chaco y los caiguáes de la Oriental.

Durante la guerra con la triple alianza, el Paraguay perdió más de 500.000 habitantes, de los cuales se calculan 160.000 muertos en los campos de batallas; 40.000 lanceados, fusilados y sacrificados en el terrible tormento del Cepo uRuguayano que tuvo su mayor aplicación en San Fernando y Lomas Valentinas; 200.000 sucumbieron de las diferentes epidemias de sarampión, neumonia, viruela y cólera asiático, que comenzaron á azotar la población desde Humaitá. Antes de haber corrido sangre en las batallas, la República había perdido 50.000 hombres en los hospitales. Posteriormente, la mayor parte murieron de hambre, desde el campamento de Ascurra hasta Cerro-Corá.

El cuadro siguiente demuestra el movimiento de población de la República, desde su fundación.

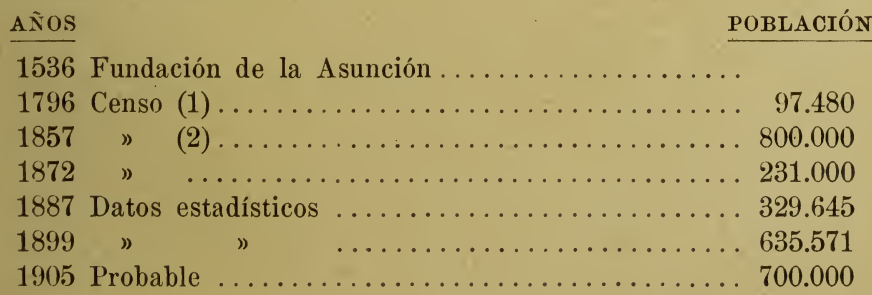

(1) Apéndice 26.

(2) Apéndice 27. 
V.

\section{Instrucción Pública.}

La INSTRUCCión PÚBLICA es gratuita y constituye uno de los deberes primordiales del gobierno y ella está al alcance de todas las clases sociales. Se divide en instrucción primaria, secundaria y universitaria.

La instrucción PRIMARIA ó educación común, es obligatoria, y el Estado sostiene actualmente 354 escuelas de uno y otro sexo, que comprenden escuelas graduadas, rurales inferiores, rurales superiores y elementales. A estas escuelas concurren más de 30.000 alumnos.

La instrucción SECUNDARIA para los cursos universitarios, se dan en cinco Colegios Nacionales establecidos, uno en la capital y los demás en Villa Concepción, Villa Rica, Villa Encarnación y Villa del Pilar.

La enseñanza universitaria se dá en la Universidad Nacional de la República que abraza las facultades de derecho y ciencias sociales, medicina, matemáticas y notariado.

La Universidad fué creada por ley de 1889 y su instalación tuvo lugar en 1890 (1).

Existen además, dos Escuelas Normales donde se preparan para ejercer el magisterio; una Escuela de Agricultura en la Santísima Trinidad en donde se preparan para ejercer la agronomía; y una Escuela Militar, recientemente creada, en donde se preparan para la carrera militar.

Seminario Conciliar.-Fundado en 1881, con el propósito de instruir y preparar á los jóvenes dedicados á la carrera eclesiástica (2). 
VI.

\section{Industria.}

La industria paraguaya es rudimentaria aún, por la carencia de brazos y capitales que exploten las variadas y ricas producciones del país.

Las más importantes son:

La GANADERía, que de día en día va tomando mayor desarrollo, merced á los vastos y ricos campos con que cuenta. Los

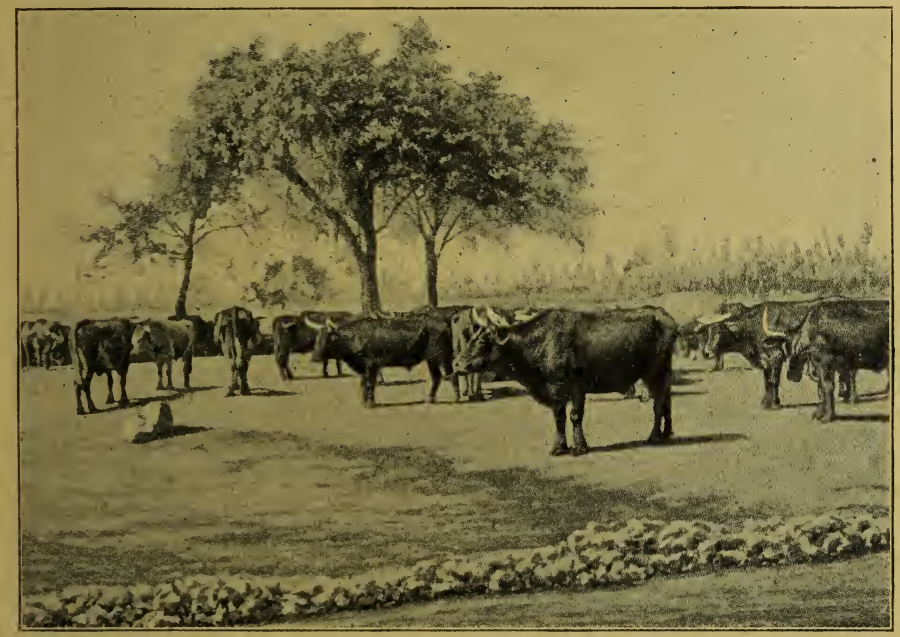

Rodeo de vacas en la Cabaña La Concepción de Emboscada.

animales vacunos, caballares, y ovinos comienzan á mejorar con la cruza de mejores razas que se introducen.

Viene en seguida la elaboración de la Yerba-mate (1) (ILEX PARAGUAYENSIS), molida y en hojas media tostadas, que no baja de 8.000.000 de kilógramos al año, empleándose en ella más de 25.000 brazos.

La yerba mate, cuyas propiedades tónicas y digestivas son bien conocidas, ha sido considerada como el té americano por excelencia.

(1) Apéndice 30 . 
Después de la ganadería y la elaboración de la yerba-mate, la principal industria consiste en la explotación de los inmensos Bosques, tanto de la región Oriental cuanto de la Occidental, que constituyen la gran riqueza forestal paraguaya.

La AGRICULtura en general, que consiste especialmente en el cultivo del tabaco, producto agrícola más importante del Paraguay; la caña de azúcar, á la que se han consagrado con tesón y fé numerosas personas; del café, que está tomando gran incremento su plantación, en vista de los resultades satisfactorios obtenidos; del algodón, que también esta tomando gran interés su plantación en atención al rendimiento que produce; del arroz, la mandioca, la papa, la batata, los porotos, del maní, el maiz y de una gran diversidad de legumbres.

De la industria SALADERIL, establecidas dos en el partido de Villa Concepción, preparan extracto de carne, lenguas conservadas y tasajo.

La producción de AzúCAR que en tres ingenios se elabora lo necesario para el consumo del país: uno en el Tebicuary, (Ibitimi) y los otros dos en Caraguatay y Luque.

La producción de suelas y toda clase de cueros curtidos se efectuan en muchas curtiembres.

La explotación de las PIEDRAs para enlozado y construcción, de la CAL en Villa Concepción, de la saL en Lambaré y por último del tanino para curtir, en la región Occidental.

Las fábricas de AGUARDIENTE DE CAÑA DE AZÚCAR, CIGARROS, habiendo adquirido reputación los de Villa Rica; de LADRILLOS y TEJaS, casi en toda la República; de alfarería. á que se dedican con preferencia los naturales de Itá y Yaguarón; de IICOREs, de aguas gaseosas, hielo, Fósforos y velas de estearina, son muchas.

Existen además varias de nuebles, de calzados y de ALPARGATAS.

Las industrias manuales tienen todas numerosos representantes en el país, figurando entre ellos, el PONCHO-PARÁ, la JERGA-PARAI y las HAMACAS. 
Y por último, el bordado llamado Ñandutí (tela de araña) que constituye una industria casera de mucha aceptación en el país y fuera de él por lo delicado y caprichoso de sus dibujos, lo ténue del tejido y por el tiempo y paciencia que exije su confección.

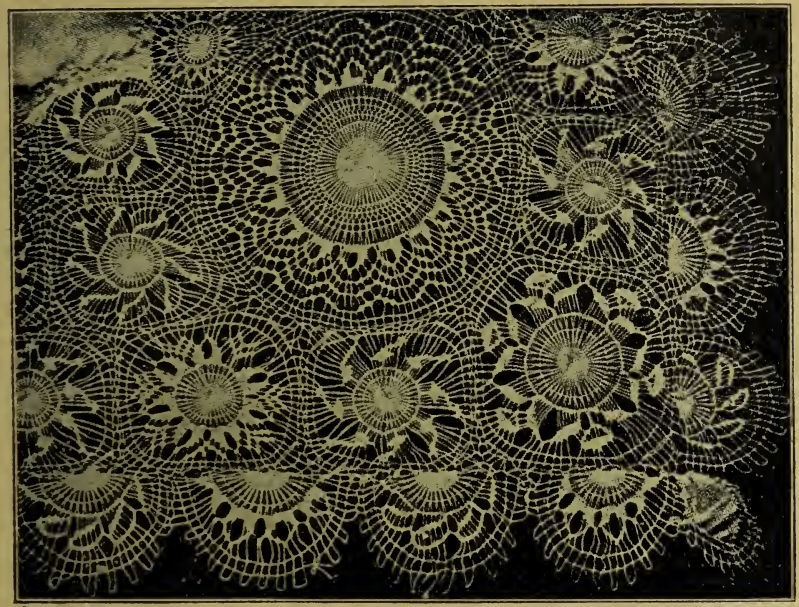

Ñandutí.

En la capital existen tres MoLINos HaRINERos á vapor; en dos de ellos se fabrican también fideos, con materias primas importadas de los mercados del Plata.

VII.

\section{Comercio.}

La República del Paraguay, favorecida por dos caudalosos ríos que la ponen en fácil comunicación con los mercados del Plata y los de Europa, puede exportar directamente sus productos á los de estos últimos; pero hasta hoy su comercio principal está limitado á las plazas comerciales de la Argentina y Uruguay.

El comercio de importación es de 3.500 .000 pesos oro al año.

En cambio de los artículos manufacturados, comestibles, bebi- 
das, artefactos, materias primas para diferentes clases de fábricas, máquinas y otra multitud de artículos introducidos en la República, se exporta yerba-mate molida y en hojas media tostadas (mboroviré), maderas, carne salada, extracto de carne, lenguas conservadas, cueros, astas, huesos, cerda, plumas de avestruz y de garza, cigarros, aguardiente, lícores, naranjas, ananás, variedad de plantas, cera, etcetera.

La exportación no baja de 4.000 .000 de pesos oro, con lo que se tiene un beneficio de 1.000 .000 aproximadamente.

También se sostiene un activo y valioso comercio entre unos y otros pueblos de la República, así como con el Estado de MattoGrosso (Brasil).

\section{VIII.}

\section{Vías de comunicación.}

La naturaleza ha provisto al país de importantes ríos navegables que constituyen hasta hoy, sus principales vías de comunicación fluviales.

Varias compañías de vapores establecen la comunicación fluvial entre la Asunción y los diversos puertos de la República con los del extranjero.

Cuatro vapores semanales hacen la carrera de Montevideo y Buenos Aires hasta el puerto de Asunción, con escala en todos los puertos argentinos y de la República; dos mensuales en la carrera de Río de Janeiro á Matto-Grosso, haciendo las mismas escalas que los anteriores; cinco semanales que hacen la carrera de Asunción á Villa Concepción con escala en todos los puertos de su tránsito; tres mensuales, en la carrera de Corrientes hasta Posadas, tocando en los puertos argentinos y paraguayos de las márgenes del río Paraná: uno que hace la carrera de Villa Encarnación hasta TacurúPucú, y finalmente un sin número de vapores de carga, buques de vela y chatas que recorren incesantemente los ríos de la República.

Todas las poblaciones de la República están en comunicación directa entre sí por medio de caminos ámplios que se procuran mantener en buen estado, para que el tráfico sea expedito.

Desde el 14 de Mayo de 1861 contaba la República con una vía férrea que unía la capital con Paraguarí, distante 72 kilómetros. 
En el día esta vía se ha prolongado hasta cerca del río Pirapó, 178 kilómetros más, y debe construirse hasta Villa Encarnación, distante 370 kilómetros de Asunción.

Las estaciones intermedias desde Asunción hasta Paraguarí, son: Trinidad, Luque, Areguá, Patiño-cué, Tacuaral, Pirayú y Cerro León; y de Paraguarí á Pirapó las que siguen: General Escobar, Sapucai, General Caballero, Ibitimí, Itapé, Hiati, Villa Rica, Borja, Santa Clara, Maciel, Sosa, González y Pirapó.

Existen varias leyes autorizando la construcción de nuevas vías férreas con la garantía del gobierno y entre ellas, una que partiendo de frente á Formosa, punto de empalme con el Ferrocarril Argentino, pase por Villa Oliva, Palmas, Angostura, Carapeguá, Ibitimí, San José, Ajos, Carayaó, Unión, San Estanislao y termine en Bella Vista. Habrá además un ramal que partirá de Angostura, pasando por los puertos de Villeta, Ipané, San Lorenzo, Lambaré y Asunción. Otro proyecto de ferrocarril, se refiere á una línea que partiendo de este último punto, pase por Emboscada, Arroyos y Esteros, San Estanislao y termine en la frontera brasileña de Igatimí.

Muchas mensajerias recorren los principales pueblos del interior de la República, auxiliando al ferrocarril y á los vapores para el transporte de pasajeros.

\section{IX.}

\section{Telégrafos.}

De Asunción salen tres líneas telegráficas que miden más de 2.000 kilómetros y la ponen en comunicación con la mayor parte de los pueblos importantes de la República y con el exterior. Una nacional vá al Paso de la Patria, cruza el rín Paraná por un cable y unida á la argentina nos comunica con las Repúblicas del Plata y de consiguiente con el antiguo y nuevo continente. Otra que vá á Bahía Negra, que en breve quedará terminada y que será unida con la brasileña, la pondrá en comunicación con el Estado de Matto-Grosso y por ende con todo el Brasil, y finalmente, otra que pertenece á la empresa del ferro-carril que recorre todas las estaciones de esta vía. 
$\mathrm{X}$.

\section{Renta y presupuesto.}

Las fUentes de Recursos con que hasta hoy cuenta la Nación, son los impuestos aduaneros, el producto de la venta de tierras públicas y yerbales, la contribución territorial, etc., cuyo monto se calcula en unos 21.000 .000 de pesos fuertes, anuales.

El presupuesto está calculado en unos 20.000.000 de pesos fuertes, anuales.

\section{$\mathrm{XI}$. \\ Pesas y medidas.}

El sistema métrico-decimal fué adoptado en el Paraguay para los usos oficiales desde el año 1901 y hoy se encuentra ya muy generalizado.

\section{XII.}

\section{Inmigración y colonización.}

Después de la guerra pasada se ha sentido una notable escasez de brazos, y el gobierno, comprendiendo la necesidad de la población, ha dictado leyes oportunas para atraer á los inmigrantes.

El país ofrece en propiedad á todo inmigrante con familia un lote de tierra de 20 hectáreas en las colonias agrícolas, pagadero su importe á precio de costo, por anualidades en cinco años; facilitándole también, un pasaje de segunda clase para su trasporte desde cualquier punto del río de la Plata; desembarco, alojamiento y mantención, y finalmente, introducción libre de toda clase de derechos á las prendas de uso personal, muebles y enseres de servicio doméstico.

Con el fin de hacer conocer estas disposiciones, se han establecido, una oficina de inmigraciones y canjes en la Asunción, cinco oficinas de propaganda en Europa, y una en la República Argentina.

Un hotel para los inmigrantes que lleguen, se costea también por la Nación. 
Las colonias establecidas en la República son:

\section{NACIONALES.}

Nueva Australia y 25 de Noviembre, en el partido de Ajos.

Trinacria, en el partido de Villa del Rosario.

Sebastian Gaboto, sobre el río Paraguay, en el partido de Villa Franca.

\section{PARTICULARES.}

Risso y Puerto Max, en el partido de Villa Concepción, sobre el río Paraguay.

Nueva Germania, sobre el río Jejuí, en el partido de Villa de San Pedro.

Elisa, en el partido de San Antonio, sobre el río Paraguay. Cosme, en Caazapá.

Hohenau, en Jesús y. Trinidad. 


\section{QUINTA PARTE.}

\section{ORGANIZACIÓN POLÍTICA.}

I.

\section{Poder Ejecutivo.}

Por la Constitución jurada el 25 de Noviembre de 1870 el Poder Ejecutivo de la República es desempeñado por un ciudadano paraguayo con el título de Presidente de la República del Paraguay, que dura en sus funciones el término de cuatro años.

La Vice-Presidencia de la República es igualmente desempeñado por un ciudadano paraguayo, que preside el Senado y dura el mismo tiempo que el Presidente. Tanto éste como aquél, no pueden ser reelejidos, sino despues de dos períodos de intérvalo.

En caso de enfermedad, ausencia de la capital, muerte, renuncia ó destitución det Presidente, el Poder Ejecutivo es ejercido por el Vice-Presidente de la República. En caso de destitución, muerte, dimisión ó inhabilidad del Presidente y Vice-Presidente, el Congreso designa el funcionario público que debe desempeñar la Presidencia, hasta que haya cesado la causa de inhabilidad ó un nuevo Presidente sea electo.

Para la elección de Presidente y Vice-Presidente se procede del modo siguiente: cada uno de los distritos electorales nombra por votación directa una Junta de Electores, igual al cuádruplo de Diputados y Senadores que envía al Congreso. 
Dos meses antes que termine el período del Presidente y VicePresidente cesantes, los electores reunidos en la capital de sus respectivos distritos, efectúan la elección, procediendo el Congreso al escrutinio y á la proclamación inmediata para Presidente y Vice-Presidente de los candidatos que hubiesen tenido la mayoría absoluta de votos.

El Presidente de la República es Jefe Supremo de la Nación y tiene á su cargo la administración general del país. Expide las instrucciones y reglamentos que son necesarios para la ejecución de las leyes; las sanciona y promulga; nombra los magistrados del Superior Tribunal de Justicia con acuerdo del Senado; puede indultar ó conmutar las penas; nombra y remueve los Agentes Diplomáticos, también con acuerdo del Senado, y por sí solo nombra y remueve á los Ministros del Despacho; ejerce el derecho del Patronato Nacional de la República en la presentación de los Obispos para la Diócesis de la Nación á propuesta del Senado, de acuerdo con el Senado eclesiástico ó en su defecto, del clero nacional reunido; concede el pase ó retiene los decretos de los concilios, las bulas, breves y rescriptos del Sumo Pontífice, con acuerdo del Senado; hace anualmente la apertura de las sesiones del Congreso; proroga las sesiones ordinarias y convoca á extraordinarias; hace recaudar las rentas de la Nación y decreta la inversión con arreglo á los presupuestos de gastos; concluye y firma tratados de paz, de comercio, de navegación, de alianza, etc., etc.

Además, es Comandante en Jefe de todas las fuerzas de la Nación; provee los grados militares hasta el de capitán y los superiores propone al Congreso, y por sí sólo en el campo de batalla; declara la guerra y restablece la paz con autorización y aprobación del Congreso; declara el estado de sitio, etc., etc.

Cinco Ministros Secretarios, á saber: del Interior, de Relaciones Exteriores, de Hacienda, de Justicia, Culto é Instrucción Pública y de Guerra y Marina refrendan y legalizan los actos del Presidente. 


\section{Ministerio del Interior.}

Las dependencias principales de este ministerio, son: la Dirección General de Correos y Telégrafos, la Jefatura Política de la capital y las de Campaña, la Oficina de Estadística, la Escribanía Mayor de Gobierno, el Departamento Nacional de Ingenieros y el Consejo Nacional de Higiene.

\section{Ministerio de Hacienda.}

La Tesorería y Contaduría General de la Nación, la Aduana de la capital y de todo el litoral de la República, el Banco Agrícola, la Oficina de Impuestos Internos y la Caja de Conversión.

\section{Ministerio de Relaciones Exteriores.}

Las legaciones en las Repúblicas Argentina, Oriental del Uruguay, Estados-Unidos del Brasil, Francia, Gran Bretaña y España, los Consulados, el Departamento General de Inmigración, las colonias en general, la Oficina de informaciones y canjes y las oficinas de propaganda en Europa.

\section{Ministerio de Justicia, Culto é Instrucción pública.}

El Registro General de la Propiedad, el Obispado y las Iglesias, el Consejo Superior de Educación (primaria) y el Consejo Secundario y Superior.

\section{Ministerio de Guerra y Marina.}

El Estado Mayor General, el Hospital Militar, la Capitanía de la capital y las de todo el litoral de la República, las Comisarías Marítimas, las Comandancias Militares de los partidos de campaña, los cuarteles en general y la Marina.

II.

\section{Poder Judicial.}

El Poder Judicial de la República es ejercido por un Superior Tribunal de Justicia, compuesto de tres miembros; dos Cámaras 
Superiores de Apelaciones y demás jugados inferiores. Los miembros del Superior Tribunal de las Cámaras de Apelaciones y los jueces que desempeñan sus funciones duran cuatro años.

Los miembros del Superior Tribunal de Justicia son nombrados por el Poder Ejecutivo de la Nación, con acuerdo del Senado.

Sólo el Poder Judicial puede conocer y decidir en asuntos de carácter contencioso; su potestad es exclusiva en ellos.

El Superior Tribunal es la Alta Cámara de Justicia en la República y en tal carácter ejerce una inspección de disciplina en todos los juzgados inferiores.

La defensa es libre para todos ante los Tribunales de la. República.

Las Cámaras de Apelaciones, juzgados y empleados inferiores se componen en la capital así: dos Cámaras, uno en lo Civil y otra en lo Comercial y Criminal, seis jueces de $1^{\text {a }}$ Instancia en lo Civil, tres en lo Criminal, uno en lo Comercial, un Presidente del Tribunal de Jurados, un Defensor General de Pobres, y otro de Menores y Ausentes, dos Procuradores de Pobres, tres Jueces Correccionales, un Juez de Paz en cada parroquia, etc., etc., y en la campaña, un Juez de $\operatorname{Paz}$ y otro Suplente en cada partido.

\section{III.}

\section{Poder Legislativo de la Nación.}

El Congreso se compone de dos Cámaras, una de Diputados y otra de Senadores, investidas del Poder Legislativo de la Nación.

La Cámara de Diputados se compone de veinte y seis miembros, elegidos, veinte por los distritos electorales de la República y seis por los de la capital.

A la Cámara de Diputados corresponde exclusivamente la iniciativa de las leyes sobre contribuciones y reclutamiento de tropas.

Sólo ella ejerce el derecho de acusar ante el Senado al Presidente, Vice-Presidente, sus ministros, á los miembros del Superior Tribunal de Justicia y á los Generales del Ejército ó Armada en las causas de responsabilidad que se intente contra ellos. 
El Senado se compone de trece miembros elegidos, tres por los distritos de la capital y los otros diez, uno por cada dos distritos electorales de la República. Tienen dos años más de duración que los Diputados.

Al Senado corresponde juzgar en juicio público á los acusados por la Cámara de Diputados. Cuando el acusado es el Presidente de la República ó Vice-Presidente en ejercicio del Poder Ejecutivo, el Senado es presidido por el Presidente del Superior Tribunal de Justicia.

Anualmente se reunen ambas Cámaras en sesiones ordinarias que duran desde el $1^{0}$ de Abril hasta el 30 de Septiembre.

El número de Diputados y Senadores señalados por la Constitución fué, para la primera Legislatura, el que hoy existe, debiendo para la segunda levantarse el censo general y arreglarse á él el número de diputados á razón de uno por cada seis mil habitantes ó una fracción que no baje de tres mil, y el de Senadores de uno por cada doce mil habitantes ó de una fracción que no baje de ocho mil. Sin embargo de haberse levantado el que señalaba la cifra de 329.645 habitantes, á que corresponderían cincuenta y cuatro Diputados y veintisiete Senadores, las cosas siguen hasta el presente en el mismo estado, manteniéndose el número de la primera Legislatura.

El Congreso legisla sobre aduanas y establece los derechos de importación y exportación; impone contribuciones directas por tiempo determinado, siempre que la defensa, y bienestar del Estado lo exijan; contrae empréstitos de dinero sobre créditos de la Nación; arregla el pago de la deuda interior y exterior; fija anualmente el presupuesto de gastos de la Administración de la Nación y aprueba ó desecha la cuenta de su inversión; reglamenta la libre navegación de los ríos; habilita los puertos que considere convenientes; crea ó suprime aduanas.

Además de estas atribuciones, hace sellar monedas; fija su valor y el de las extranjeras y adopta un sistema uniforme de pesas y medidas para toda la Nación; reglamenta el comercio marítimo y terrestre con las naciones extranjeras; dispone del uso y de la enajenación de las tierras; dicta códigos; arregla los límites del territorio nacional; provée á la seguridad de las fronteras; establece tribunales; declara en estado de sitio uno ó más 
puntos de la República; fija las fuerzas de línea de mar y tierra; aprueba ó desecha los tratados concluidos con las demás naciones y por último, dicta todas las leyes necesarias para poner en ejercicio los poderes que dispone la Constitución.

\section{IV.}

\section{Diócesis Episcopal.}

La República del Paraguay forma una sola Diócesis siendo Jefe de la Iglesia Nacional un Obispo, que es ciudadano paraguayo. Ejerce éste su jurisdicción sobre todos los curatos de la capital y campaña. Tiene todas las facultades conferidas á los Ordinarios por las leyes canónicas.

Depende del Obispo el Seminario Conciliar, y en los casos de vacantes, designa un Vicario interino y nombra vicarios foráneos para la campaña.

V.

\section{Municipalidad.}

Los intereses comunales de la Asunción están á cargo de la Municipalidad, compuesta de un Concejo Deliberante y de un Departamento Ejecutivo.

El primero está formado de doce concejales elegidos, cuatro para cada distrito electoral, renovados por mitad cada año, pudiendo ser reelectos.

El empleo de concejal es carga pública y nadie puede excusar su desempeño sino oponiendo justa causa.

Los extranjeros gozan de voto activo y pasivo en las elecciones municipales.

Los miembros del Concejo Deliberante son responsables ante los Tribunales por las faltas ó delitos cometidos en el desempeño de sus funciones.

La Municipalidad dicta todas las ordenanzas, medidas y disposiciones tendentes á la percepción, dirección y administración de las propiedades é intereses locales del municipio. 
Las cuestiones de competencia de jurisdicción entre la Municipalidad y cualquiera otra autoridad, son resueltas por el Superior Tribunal de Justicia, y los que se consideren perjudicados por sus resoluciones, pueden igualmente apelar ante el mismo Tribunal, cuya decisión es definitiva.

El Departamento Ejecutivo, lo desempeña un funcionario llamado Intendente Municipal, nombrado y removido por el Presidente de la República.

El Intendente promulga las ordenanzas y provée á su ejecución; hace recaudar los impuestos municipales; aplica en cada caso las multas que establecen las ordenanzas; observa en el término de diez días las ordenanzas del Concejo; pero si ésta insistiera en su resolución por simple mayoría de votos, deberá ejecutarlas. Además, ejerce la superintendencia y dirección inmediata de la Administración; representa á la Municipalidad en sus relaciones oficiales, y finalmente, nombra y remueve los empleados de la Intendencia, á excepción del Contador, Tesorero y Secretario, que son designados y removidos con acuerdo del Concejo Deliberante.

En los partidos de la República donde existen Municipalidades, ellas se componen de cuatro titulares y dos suplentes, que son renovados por mitad cada año, pudiendo ser reelectọs. Estas Municipalidades ejercen sus funciones sin intendencias, y se hallan todas sujetas á las mismas reglas y responsabilidades que la de la capital.

VI.

\section{Ejército y Marina.}

El ejército de la Nación, compuesto de las tres armas, infantería, caballería y artillería, monta á 3.200 plazas. Cada cuerpo tiene dos comandantes.

La marina cuenta en la actualidad con dos buques mercantes armados á guerra y de pequeños buques que se destinan al cuidado y vigilancia de las costas. 
VII.

\section{División Territorial. (1)}

La República se compone de la capital y ciento dos partidos divididos en veinte y tres distritos, en la forma siguiente:

La capital de la Asunción, comprende los tres distritos siguientes: Catedral con Recoleta. Encarnación con Lambaré y San Roque con Santísima Trinidad.

fer Distrito: Villa Concepción, Horqueta, Belen, Bella Vista, Pedro Juan Caballero y Loreto.

$2^{\circ}$ Distrito: Villa de San Pedro, San Estanislao, Villa del Rosario, Itacurubí del Rosario, Lima, Unión, Tacuaty, Villa Igatimí y Villa Curuguaty.

$3^{\text {er }}$ Distrito: Altos, Arroyos y Esteros, Caacupé, Tobatí, Emboscada, Atyrá y San Bernardino.

$4^{\circ}$ Distrito: Barrero Grande, Caraguatay y Piribebuy.

$5^{\circ}$ Distrito: Ibitimí, Valenzuela, Itacurubí de la Cordillera y Caballero.

6 Distrito: Ajos, Caaguazú, San Joaquin, Carayao é Ihú.

$7^{\circ}$ Distrito: Villa Rica.

$8^{\circ}$ Distrito: Hiaty, Itapé, Mbocayaty y Yataity.

9 Distrito: Caazapá, Ihacanguazú, Iturbe y San Juan Nepomuceno.

10 Distrito: Yutí, Bobí, San Pedro del Paraná y Yegros.

11 Distrito: Villa Encarnación, San Cosme, Jesús y Trinidad y Carmen del Paraná.

$12^{\circ}$ Distrito: San Ignacio, San Juan Bautista, Santiago, San Miguel, Santa Rosa, Santa María y Villa Florida.

$13^{\circ}$ Distrito: Ibicuí, Mbuyapey y Quiquió.

14 Distrito: Quiindy, Acahay y Caapucú.

15 Distrito: Paraguarí, Carapeguá, Tabapy y Escobar.

16 Distrito: Itauguá, Pirayú, Areguá é Ipacaraí.

$17^{\circ}$ Distrito: Luque, San Lorenzo del Campo Grande, San Lorenzo de la Frontera, Limpio y Villa Hayes.

(1) Apéndice 31 . 
$18^{\circ}$ Distrito: Itá, Capiatá, Yaguaron, Guarambaré é Ipané.

$19^{\circ}$ Distrito: Villa Oliva, Villeta, Villa Franca y San Antonio.

20 Distrito: Villa del Pilar, Villa de Humaitá, Paso de Patria, Yabebiry, Isla Umbú, Laureles, Tacuaras, Desmochados, Pedro González, San Juan Bautista de Ñeembucú y Guazucuá.

\section{VIII.}

\section{Pabellón y sello Nacional. (1)}

El pabellón nacional de la República del Paraguay con los colores y atributos que dispuso el Soberano Congreso General Extraordinario reunido el 25 de Noviembre de 1842, aparece en la lámina adjunta.

La bandera es de forma cuadrilonga $\mathrm{J}$ compuesta de tres fajas: colorada, blanca y azul, iguales y horizontales.

Aún cuando el Congreso no determinó las dimensiones de la bandera, el tamaño generalmente empleado es de 5 metros de largo, por 2.70 de ancho, teniendo 90 centímetros cada faja de los colores.

En el centro de la bandera figuran: de un lado el escudo nacional con una palma y una oliva entrelazadas en el vértice y abiertas en la superficie, resaltando en medio de ellas una estrella, y en la orla la inscripción República deL PARAGUAY, y en el lado opuesto, un círculo con la inscripción PAZ y Justicia y en el centro un león sentado en la base del símbolo de la libertad, ó sea al pié de una pica que sostiene en la extremidad superior el gorro frigio.

La bandera con su correspondiente escudo es la que se enarbola en las plazas, puertos, campamentos, fortalezas y buques de guerra de la República.

El sello nacional á tinta ó para lacre, es el mismo ya descrito del escudo del primer lado; y para sello de Hacienda, el del lado opuesto y República det Paraguay en la orla.

(1) Apéndice 32. 


\section{PABELLON Y E}

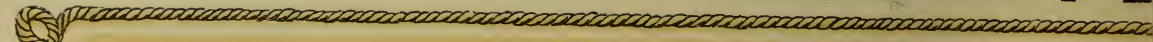

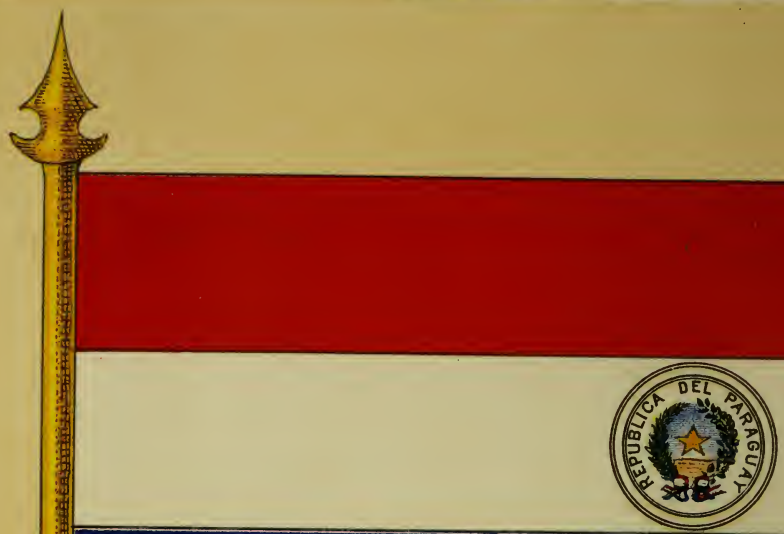

Sello de

Hacienda

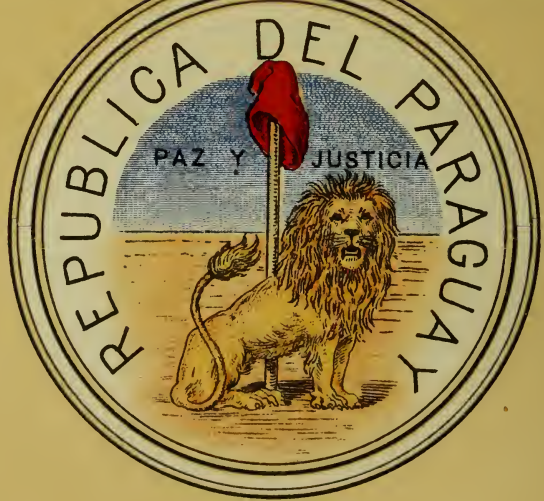

U. F. A. Brockhaus, Leipzig. 


\section{CUDO NACIONAL.}

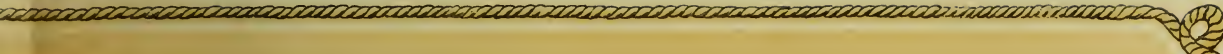
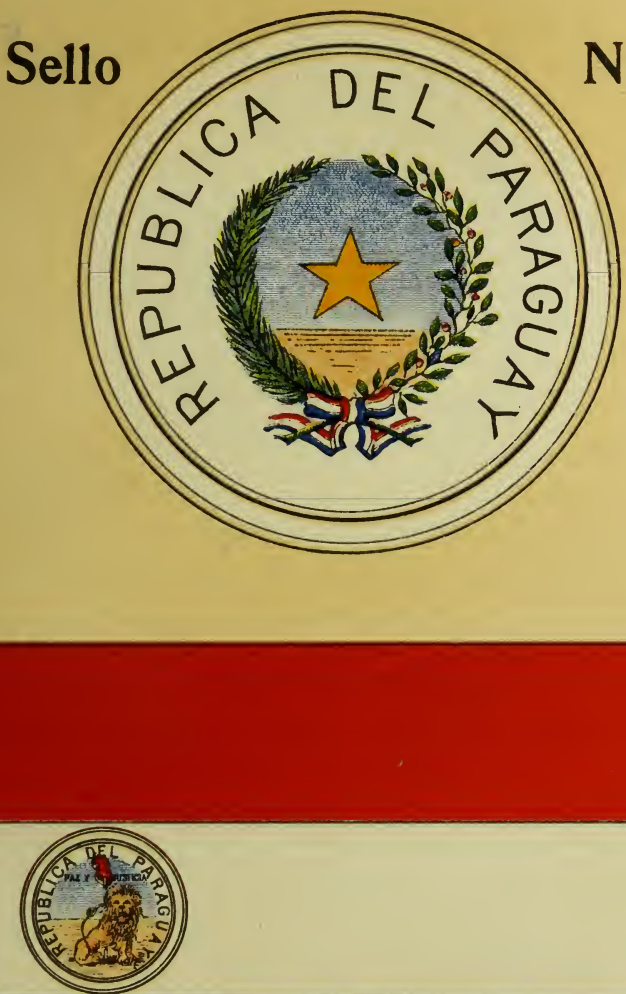

Nacional 



\section{Apéndice.}

1. Los límites con el Brasil y la Argentina, están ya definitivamente establecidos: los del primero, por el tratado de 9 de Enero de 1882, que establece lo siguiente:

"Artículo $1^{\circ}$. - La República del Paraguay, y Su Alteza la Princesa Imperial del Brasil, Regente en nombre del Emperador, el señor Don Pedro II, estando de acuerdo en señalar sus respectivos límites, convinieron en declararlos, definirlos y reconocerlos del modo siguiente:

(El territorio del Imperio del Brasil se divide con el de la República del Paraguay por el cauce ó canal del río Paraná, desde donde comienzan las posesiones brasileñas en la boca del Yguazú, hasta el Salto Grande de las siete caídas del mismo río Paraná.

"Del Salto Grande de las siete caídas, continua la línea divisoria por la cumbre de la sierra Mbaracayú, hasta donde ella concluye.

"De ahí, sigue en línea recta, ó que más se le aproxime, por los terrenos más elevados á encontrar la sierra de Amambay.

"Prosigue por lo más alto de esta sierra, hasta la naciente principal del río Apa, y baja por el canal de éste, hasta su boca en la margen oriental del río Paraguay.

"Todas las vertientes que corren para el Norte y Este, pertenecen al Brasil, y las que corren para el Sud y Oeste, pertenecen al Paraguay.»

Con la República Argentina, fueron determinados por el tratado de límites de 3 de Febrero de 1876 que en su parte pertinente establece:

"Artículo $1^{\circ}$. - La República del Paraguay se divide por la 
parte del Este y Sud de la República Argentina, por mitad de la corriente del canal principal del río Paraná, desde su confluencia con el río Paraguay, hasta encontrar por su margen izquierda los límites del Imperio del Brasil, pertenecienda la isla de Apipé á la República Argentina, y la isla de Yaciretá á la del Paraguay como se declaró en el tratado de 1856.

"Art. $2^{\circ}$. - Por la parte del Oeste, la República del Paraguay se divide de la República Argentina, por la mitad de la corriente del canal principal del río Paraguay, desde su confluencia con el río Paraná, quedando reconocido definitivamente como perteneciente á la República Argentina el territorio del Chaco, hasta el canal principal del río Pilcomayo, que desemboca en el río Paraguay en $\operatorname{los} 25^{\circ} 26^{\prime}$ de la latitud Sud, según el mapa de Mouchez, y $25^{\circ} 22^{\prime}$, según el de Brayer.

"Art. $4^{\circ}$. - El territorio comprendido entre el brazo principal del Pilcomayo y Bahía Negra se considerará dividido en dos secciones, siendo la primera la comprendida entre Bahía Negra y el río Verde que se halla en $\operatorname{los} 23^{\circ} 1^{\prime}$ de latitud Sud, según el mapa de Mouchez, y la segunda, la comprendida entre el mismo río Verde y el brazo principal del Pilcomayo, incluyéndose en esta sección la Villa Occidental.

"El gobierno argentino renuncia definitivamente á toda pretensión ó derecho sobre la primera sección.

"La propiedad ó derecho en el territorio de la segunda sección, incluso la Villa Occidental, queda sometido á la decisión de un fallo arbitral.»

El fallo arbitral del Presidente de los Estados Unidos de Norte América decidió la cuestión en la forma siguiente:

"Con ésta, se da ahora á conocer que yo:

"Rutherford V. Hayes, Presidente de los Estados Unidos de América despues de haber tomado en debida consideración las dichas exposiciones y documentos fehacientes, juzgo: que la dicha República del Paraguay tiene los títulos perfectos y legales á la posesión del dicho territorio discutido entre el Pilcomayo y río Verde y de la Villa Occidental situada entre ellos, y de con- 
siguiente concedo á la dicha República del Paraguay el territorio en la orilla occidental del río del mismo nombre, entre el río Verde y el brazo principal del Pilcomayo, incluyendo la Villa Occidental.

"Washington, el día doce de Noviembre, en el año de Nuestro Señor, mil ochocientos setenta y ocho.»

Los límites con Bolivia no están aún establecidos. El Paraguay alega, fundándose en documentos auténticos é indisputables, que sus líneas divisorias son las que se han mencionado, sobre las cuales no admite discusión alguna; dejando, sin embargo, imprejuzgados los derechos históricos que tiene sobre los territorios occidentales situados más al norte de sus límites, que ascienden á unos 100.000 kilómetros cuadrados.

2. La circunstancia de ser este ARROYo nuestro actual límite, en vez de todo el curso del río Apa, como lo dispone el anterior tratado, es debido á la generosidad del Gobierno de Salvador Jovellanos, que contrariando la opinión técnica del comisionado paraguayo Domingo A. Ortiz, fijó el arroyo Estrella como NACIENTE PRINCIPAL del río Apa.

3. Esta isla fué un sitio sagrado de los payaguaes y allí se encuentran los sepulcros de la valerosa raza hoy extinguida.

4. Nombre de un cacique que habitaba en la región del Salto en la época de la conquista y SALto DE Guatrá por la proximidad de la Provincia del guatrá.

5. Este lago, cuyo nombre significa «lago conjurado» se le denominó así porque en 1603 fué bautizado por el beato Luis Bolaños, con motivo de haberse desbordado.

Entre las varias leyendas que con respecto á este mismo lago se refieren, la más general es, que antiguamente existió una fuente de agua llamada TApaicuá, que mudó este nombre por el de Ipacaraí, después de una inundación en la que pereció toda una tribu que se encontraba en sus inmediaciones y que se negó á convertirse al Cristianismo. El único que salvó fué un misionero, debido al aviso que le dió un loro.

La leyenda de otro tiempo, también refiere que á media noche 
se escuchaban ruidos atronadores, y que en medio de las sombras se veian cruzar en las aguas del lago, ejércitos de demonios.

6. En 1853 bajo la presidencia de Cárlos A. López, se estableció una importante fundición de hierro en el partido de Ibicuí, que proveyó al Arsenal de Asunción de cantidades proporcionales de hierro fundido, extraido de las minas del mismo partido, de Quiquió, San Miguel y Caapucú. Durante la guerra de la triple alianza fueron también fundidos allí con el bronce de las campanas de los templos varios cañones, algunos de los cuales se hicieron notables, tales como el "Cristiano», el "Niño» etc. En cuanto á otros minerales, muy poco han sido estudiados hasta hoy, y no será por consiguiente extraño que dada la composición geológica del suelo paraguayo, existan riquezas ignoradas, superiores á las que han sido descubiertas y explotadas.

7. Azara dice, que durante su permanencia en el Paraguay, le aseguraron que el copón de oro de una parroquía, fué sacado del cerro de Acahay.

8. En los pueblos lejanos de Asunción, se emplea en el blanqueo de casas, á falta de cal.

9. La mayor parte de los campos de pastoreo de la República poseen salinas que se designan con el nombre de BARRERos: ellas dan mayor mérito á aquellos por lo benéfico é indispensables que son á los ganados. En algunos lugares son tan abundantes, que explotados podrían abastecer al país de la sal necesaria para el consumo.

Antes de la guerra se trabajaba en grande escala en Lambaré, Luque, Ipané, etc., y ya en la época del dictador Francia, la sal que se consumia era únicamente elaborada en la República. Pero durante la guerra, su explotación fué abandonada y muchos perecieron á causa de la carencia de este mineral indispensable para la alimentación.

10. Azara pág. 12.

11. id. id. 13 .

12. Es la madera más dura que se conoce: bajo de tierra es incorruptible. De edificios construidos por los Jesuitas, se han sacado piezas de urundeymí completamente intactas. 
13. El lapacho constituye un verdadero adorno de los bosques en donde abunda este gigantesco árbol. Precioso aspecto presenta en la primavera, cubierto de miles de grandes flores rosadas y amarillas.

14. Extrujada la fruta de esta planta, se sirve de ella como el jabón.

15. La almendra dá un $40 \%$ de aceite y de sus hojas que son muy fibrosas, se hacen tejidos.

En la época de la guerra con la Triple Alianza, la población se alimentó de su semilla y del cogollo extraido del tallo.

16. Los Jesuitas se servían de este animal para combatir la borrachera, por medio de un cocimiento que, mezclado al aguardiente, daban á beber.

17. En la época de la conquista se conocía este pájaro con el nombre de pytaguá (nombre dado en guaraní á los extrangeros), significando que su canto dió aviso á los indios de la llegada de los españoles al Paraguay.

18. Durante la dictadura de José Gaspar de Francia, se tenía como anuncio de fusilamiento seguro, cuando un chavarria (chajhá) pasaba al oscurecer sobre la casa de aquel monstruo.

19. Azara, pág. 111 dice: "La chinche es desconocida de los indios y aún la desconocieron los españoles del Paraguay, hasta el año 1769, en que se supone la trajo en su equipaje el Gobernador de Buenos Aires.

20. Oriundo del que los hermanos Goes introdujeron al Paraguay en 1554, siete vacas y un toro precedentes de San Vicente del Brasil.

Tal es el origen del desarollo de estos animales en el territorio de la República, prestándose admirablemente sus fértiles campos para la rápida procreación. Durante la guerra casi desaparecieron por completo, y después de terminada, fué necesario recurrir á las repúblicas vecinas para el abastecimiento de la población.

Hoy día, mediante las condiciones benéficas del suelo, ha cesado la importación y se cuentan ya con importantes establecimientos de ganadería, con más de 3.000 .000 de cabezas. 
21. Los primeros animales de esta especie fueron introducidos por Juan de Ayolas, cuando la Conquista en 1536, y desde entonces la cria de caballos se ha propagado en el Paraguay, especialmente en la parte Sur que es la más apropiada, pues en la del Norte reina anualmente la enfermedad de MAL DE CADERA, que impide su desarrollo.

22. Las primeras ovejas y cabras fueron introducidas en 1550 , por el capitán Nuflo de Chaves, con procedencia de Chuquisaca.

23. No se conoce fijamente la época en que se introdujo en el Paraguay. Presta importantes servicios á la clase proletaria, siendo casi exclusivamente el principal vehículo de que se sirven las mujeres del mercado para la conducción de los frutos de comercio en la mayor parte le los pueblos cercanos á la Asunción. Llegan á más de mil los que diariamente entran en la capital.

24. Por ley de 13 de Mayo de 1879 , se le dió esta denominación á toda la región del Gran Chaco paraguayo.

25. Es uno de los pocos idiomas americanos que ha sido estudiado detenidamente por los Jesuitas, habiéndose escrito muchos libros que lo dan á conocer, tales como gramáticas, diccionarios, catecismos, etc. Durante la última guerra, el guaraní era el idioma del ejército y en el mismo se escribieron periódicos, poesías patrióticas y cantos populares.

26. Censo mandado levantar por el Gobernador Lázaro Rivera y Espinoza de los Monteros, antecesor de Bernardo de Velazco, como primer acto de su gobierno.

27. El Paraguay, en aquella época, era muy poco conocido en el exterior, y el Presidente Cárlos A. López en el deseo de hacerlo aparecer como una de las primeras potencias de Sud-América, hizo ascender la población á 1.337.349 habitantes, cuando en realidad no pasaba de 800.000. (Véase Du Graty, La República del Paraguay.)

28. La fundación de la Universidad de Asunción encontró al principio mucha resistencia, pero después de laboriosas discusiones, el Congreso sancionó el proyecto de ley presentado por el entónces Senador al Congreso, D. José Segundo Decoud.

29. El Seminario Conciliar es una institución que fué obra 
de la iniciativa y perseverancia de la señorita Ana Escato. Personalmente ella tomó á su cargo la tarea de recaudar fondos y sus asiduos trabajos obtuvieron el mejor resultado.

El seminario en 24 años, que lleva de fundación, ha producido cincuenta sacerdotes, figurando entre ellos el actual Obispo del Paraguay, monseñor Juan Sinforiano Bogarin.

30. Composición DE LA Yerba-Mate, SEGÚN EL ANÁLISIS DEL DOCTOR PARODI. - El árbol que produce la hoja con que se prepara la yerba que se creía ser psoralea glandulosa, ha sido colocado después en las familias de las Ilicíneas ó Gelastríneas D. C., bajo el nombre de Ilex paraguayensis ó Ilex mate.

Antes de pulverizar gruesamente esa hoja tal como nos la ofrece el comercio, se la somete á una incompleta torrefacción al aire libre, en cuya operación se coagula en parte el jugo albuminoso que contiene y se desarrolla, como en el café, un principio aromático. Se comprime ó ataca la hoja así preparada en sacos de cuero húmedo, y se la abandona á sí misma por algunos meses, con lo que adquiere un aroma agradable y un sabor particular, que bien saben apreciar los conocedores.

El principio inmediato cristalizable puede obtenerse por el mismo procedimiento con que se extrae la teína del té.

También se obtiene por sublimación, según el método propuesto por M. Stenhouse para la cafeína. Según mis ensayos, la buena yerba paraguaya contiene $1 \frac{1}{2}$ á $2 \%$ del principio inmediato, cuyas propiedades químicas són idénticas á las de la teína, cafeína, guaranina, etc. El ácido cafetánico contenido en la yerba es idéntico al tanino del café (Berzelius), que colorea las persales de hierro en verde y se halla combinado en parte con el principio cristalizable al estado de cafetanato de teína. Lo mismo que la infusión del té, la yerba contiene una sal de hierro soluble, sin ser descompuesta en presencia del ácido cafetánico. Los efectos fisiológicos del mate, además de los que le supone Liebig al café y al té, que por analogía de composición deben serle comunes, ofrecen también la propiedad de ser nutritiva por la albúmina ó caseina vegetal que abundantemente contiene. 
31. Antes de la guerra con la Triple alianza, la República se dividía en los veinte y cinco departamentos siguientes: Asunción, Acahay, Cordillerita, Cordillera, Caapucú, Villa Rica, Caazapá, Yuty, Bobí, Misiones, Villa de la Encarnación, Santo Tomás, Villa Oliva, Villa Franca, Villa del Pilar, San Estanislao, San Joaquín, Villa de San Isidro de Curuguaty, Villa de Igatimí, Villa del Rosario, Villa Concepción, Villa del Divino Salvador, Villa Occidental y Candelaria.

32. El 17 de Junio de 1811 se enarboló por primera vez en el Paraguay, la bandera tricolor, compuesta de los colores AzuL,. ENCARNADO y AMARILLO, con el escudo y las mismas armas del Rey, para distinguirse de las de Buenos Aires y Montevideo.

Más tarde, en la época del Dictador José Gaspar de Francia, el escudo de la bandera paraguaya se componía de DOS GAJOS DE OLIVA Y PALMAS ENTRELAZADAS, SUSPENDIDAS POR UNA ESTRELLA y en el exergo, República del Paraguay.

El doctor Angel J. Carranza reputado historiador y anctador de Mariano Antonio Molas, autor de Descripción Histórica DE la Antigua Provincia del Paraguax, dice: «....... que según Peña, la bandera primitiva del Paraguay (provincia entonces), FUÉ TODA AZUL Y UNA ESTRELLA BLANCA EN EL ÁNGULO SUPERIOR PRóxIMo Á LA DRIzA. La materia de que se componía, LIENzo CRUDO Ó LONETA, AÑIL Y ALBAYALDE, según algunas que se encontraron depositadas en la tesorería de la Asunción á la muerte del dictadorn.

"Cuando la restauración proscribió de Francia el pabellón tricolor que tanto lustre alcanzara en las guerras de la República y el Imperio, suplantándole el blanco x FLOR DE LIS de los Borbones-el dictador aprovechó sagazmente esta coyuntura, y por analogía con su apellido y admiración á Napoleón, se declaró heredero de dichos colores, cuyas fajas pintadas con bermellón, añil y albayalde, se usaron al principio indistintamente, ya horizontales ó verticales como se veia en las banderolas y estandartes de caballería.» 


\section{ÍNDICE.}

\section{DEFINICIONES GENERALES.}

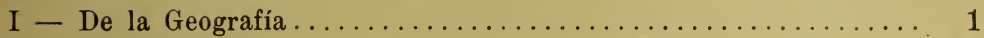

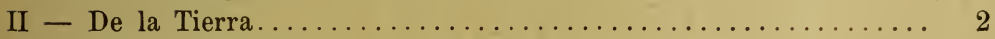

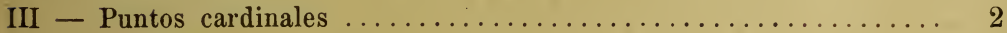

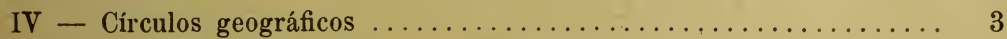

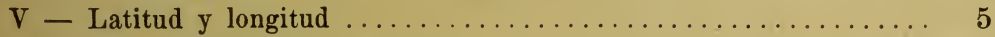

VI - Determinación de la latitud $\ldots \ldots \ldots \ldots \ldots \ldots \ldots \ldots \ldots \ldots$

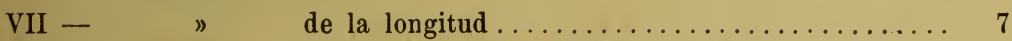

VIII - $\gg$ de la situación geográfica de un punto....... 7

IX - De la parte sólida ......................... 8

$\mathrm{X}$ - De la parte líquida ........................ 12

\section{PRIMERA PARTE.}

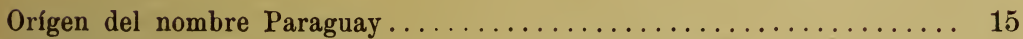

Preliminares..................................... 15

\section{REGIÓN ORIENTAL.}

Preliminares...................................... 17

\section{DESCRIPCIÓN FÍSICA.}

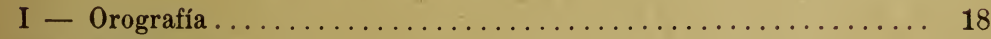

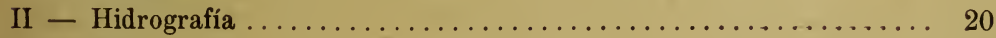

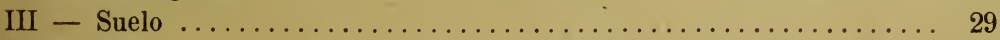

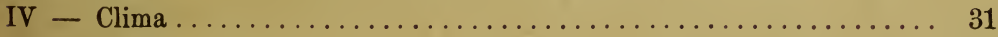

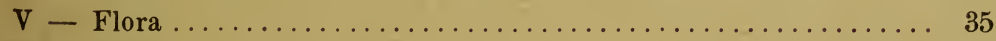

VI - Fauna ............................... 40 


\section{SEGUNDA PARTE.}

\section{DESCRIPCIÓN DE LA CAPITAL Y DE LOS DISTRITOS DE LA REPÚBLICA.}

\begin{tabular}{|c|c|}
\hline & PÁGINAS \\
\hline I - La ciudad de la Asunción & 53 \\
\hline II - Primer distrito & 66 \\
\hline III - Segundo distrito & 68 \\
\hline IV - Tercer distrito & 69 \\
\hline $\mathrm{V}$ - Cuarto distrito & 72 \\
\hline VI - Quinto distrito & 73 \\
\hline VII - Sexto distrito & 74 \\
\hline VIII - Séptimo distrito & 75 \\
\hline IX - Octavo distrito & 76 \\
\hline $\mathrm{X}$ - Noveno distrito........ & 76 \\
\hline $\mathrm{XI}$ - Décimo distrito & 77 \\
\hline XII - Undécimo distrito & 78 \\
\hline XIII - Duodécimo distrito.... & 79 \\
\hline XIV - Décimotercio distrito & 80 \\
\hline $\mathrm{XV}$ - Décimocuarto distrito & 81 \\
\hline XVI - Décimoquinto distrito & 81 \\
\hline XVII - Décimosexto distrito & 83 \\
\hline XVIII - Décimoseptimo distrito & 84 \\
\hline XIX - Décimooctavo distrito & 84 \\
\hline $\mathrm{XX}$ - Décimonono distrito.. & 85 \\
\hline XXI - Vigésimo distrito & 86 \\
\hline
\end{tabular}

TERCERA PARTE. REGIÓN OCCIDENTAL.

Orígen del nombre Chaco .......................... 88

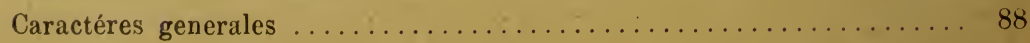




\section{CUARTA PARTE.}

\section{DESCRIPCIÓN POLÍTICA.}

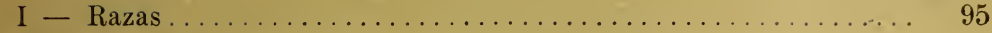

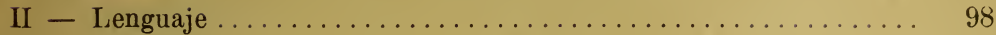

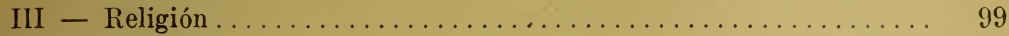

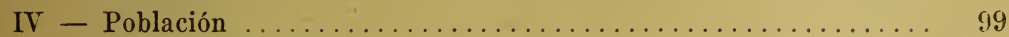

$\mathrm{V}$ - Instrucción Pública........................ 100

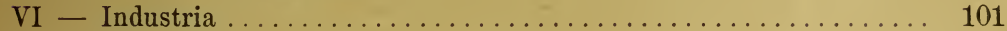

VII - Comercio .............................. 103

VIII - Vías de comunicación ......................... 104

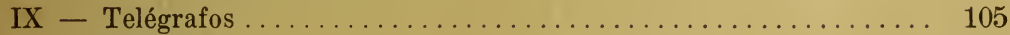

X - Renta y presupuesto ...................... 106

XI - Pesas y medidas ......................... 106

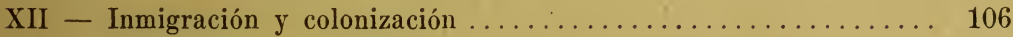

\section{QUINTA PARTE.}

\section{ORGANIZACIÓN POLÍTICA.}

I - Poder Ejecutivo ............................ 108

II - Poder Judicial ............................ 110

III - Poder Legislativo de la Nación .................... 111

IV - Diócesis Episcopal ............................ 113

V -- Municipalidad.................................. 113

VI - Ejército y Marina ............................ 114

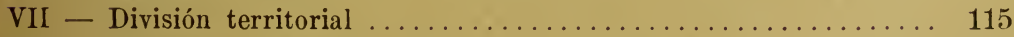

VIII - Pabellón y sello Nacional ....................... 116

Apéndice .............................. 117 



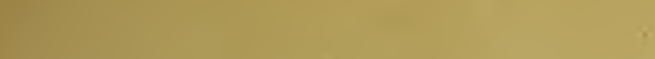

$=$

.

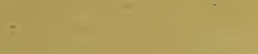

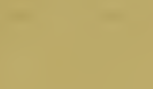

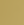

$x$

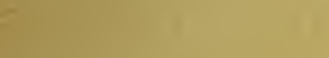

'

․․ 




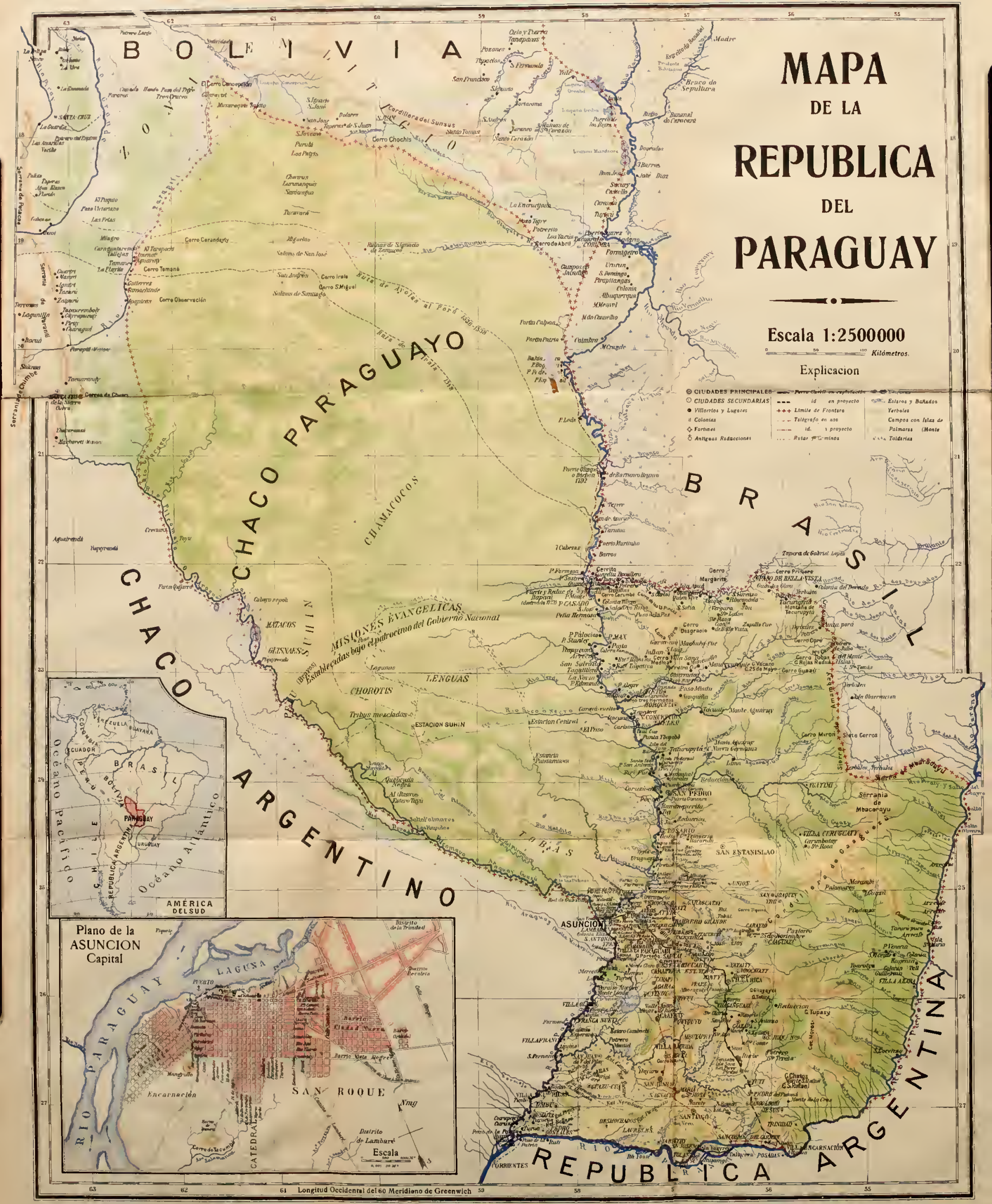



OF ILLINOIS-URBANA 30112114022640 